\title{
Temporal trends in consumption, growth, and successful feeding traits of a central Appalachian brook trout population at the watershed scale
}

Ryan Michael Utz

West Virginia University

Follow this and additional works at: https://researchrepository.wvu.edu/etd

\section{Recommended Citation}

Utz, Ryan Michael, "Temporal trends in consumption, growth, and successful feeding traits of a central Appalachian brook trout population at the watershed scale" (2005). Graduate Theses, Dissertations, and Problem Reports. 2228.

https://researchrepository.wvu.edu/etd/2228

This Thesis is protected by copyright and/or related rights. It has been brought to you by the The Research Repository @ WVU with permission from the rights-holder(s). You are free to use this Thesis in any way that is permitted by the copyright and related rights legislation that applies to your use. For other uses you must obtain permission from the rights-holder(s) directly, unless additional rights are indicated by a Creative Commons license in the record and/ or on the work itself. This Thesis has been accepted for inclusion in WVU Graduate Theses, Dissertations, and Problem Reports collection by an authorized administrator of The Research Repository @ WVU. For more information, please contact researchrepository@mail.wvu.edu. 
Temporal trends in consumption, growth, and successful feeding traits of a central Appalachian brook trout population at the watershed scale

\author{
Ryan Michael Utz
}

\author{
A Thesis \\ Submitted to \\ The Davis College of Agriculture, Forestry, and Consumer Sciences \\ West Virginia University \\ in partial fulfillment of the requirements \\ for the degree of \\ Master of Science \\ in \\ Wildlife and Fisheries Resources
}

Kyle J. Hartman, Ph.D., chair

Patricia M. Mazik, Ph.D.

Frank Panek, Ph. D.

J. Todd Petty, Ph.D.

Department of Wildlife and Fisheries

Morgantown, West Virginia 2005

Keywords: brook trout, bioenergetics, feeding strategy, distribution, trophic ecology

Copyright 2005 Ryan Michael Utz 


\section{Abstract \\ Temporal trends in consumption, growth, and successful feeding traits of a central Appalachian brook trout population at the watershed scale}

\section{Ryan Michael Utz}

Brook trout (Salvelinus fontinalis) in Appalachia frequently experience limitations in food availability. In order to determine temporal variation in consumption, successful feeding, and corresponding population patterns and growth, the feeding dynamics of a population of brook trout were monitored throughout a headwater watershed over the course of two years. The Middle Fork River brook trout experienced food limitation throughout summer and fall, however, mean consumption estimates fell below maintenance ration only during the winter seasons. Consumption estimates were significantly related to watershed position, as fish in low density, downstream reaches consistently consumed significantly more energy than fish upstream during warm months. During the summer, when fish were most energetically stressed, a significant negative relationship existed between large fish density and mean consumption estimates. Brook trout exhibited generalist feeding throughout the year and consumed a high diversity of organisms. During each season, fish observed feeding above maintenance ration consumed significantly different proportions of certain prey taxa than fish feeding below maintenance ration. Specifically, some terrestrial organisms appeared to be most important during spring, summer, and fall. The population of brook trout in the Middle Fork River watershed did not appear to be evenly distributed with respect to food resources, suggesting that the full potential of resource availability is not being exploited by the population. Alternatively, brook trout may not distribute on a food resource scale, and/or the energetic costs of movement do not equal the benefit of increased feeding. Furthermore, terrestrial organisms appear to outweigh aquatic prey in terms of prey importance to Middle Fork brook trout, implying that active riparian zone management may have consequences to central Appalachian salmonids. 


\section{Acknowledgements}

I would like to first thank Kyle Hartman for accepting me with almost no experience in fisheries and trusting that I would learn, in time, the incoherent and chaotic ways of the trout. Many thanks go out to my committee: Pat Mazik, Frank Panek and Todd Petty for putting the time into improving my work and not going too tough on me in that conference room.

Special thanks go out to Brett Moore for all of the help in the field and the lab. He deserves a great deal of credit for this document. Brett sometimes made me feel like the technician and he the boss. The world of fisheries research would benefit immensely should he decide to pursue his own graduate degree.

Thanks everyone else who helped me in the field: Chris Horn, Zach Liller, Doug Meads, Annie Miller, Jon Niles, Ken Sheehan, Garrett Staines, Jason Stolarski, Jeremy Webster, and Thomas Wilson. These guys put up with nasty field conditions and went out of their way to help; I couldn't have finished without them.

Along the way I learned my insects, and I couldn't have done this without the help of Donna Hartman and Jason Love. Without the help of George Seidel, the statistics in this document would be far less robust.

Thanks to the Division of Natural Resources and Janet Clayton for use of their lab facilities.

Funding for this project came for Mead-Westvaco, the WV Division of Natural Resources, and the US Forest Service.

Finally, thanks to Chris, Ken, Garrett, Zach, Heather, Sarah, Jason, Jon, Jered, and Jeremy for making graduate school much more enjoyable than it should have been. 


\section{Table of Contents}

Chapter 1: Literature Review............................................................................ 1

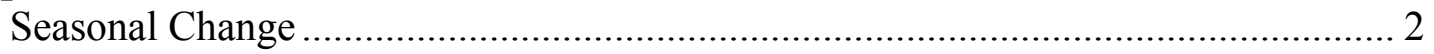

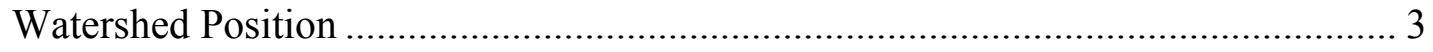

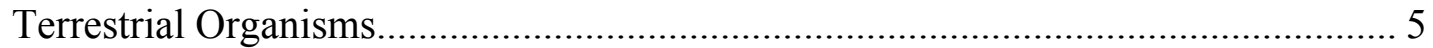

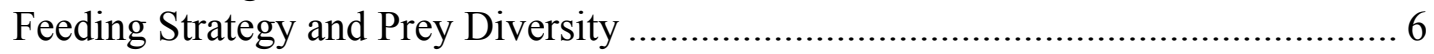

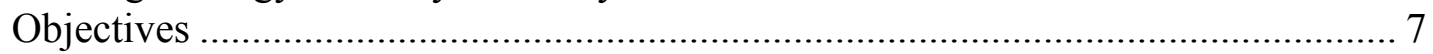

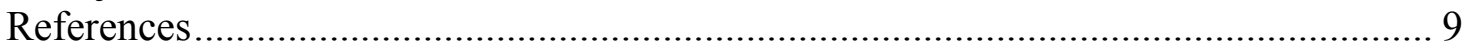

\section{Chapter 2: Temporal variation in the energy intake of Appalachian brook trout at}

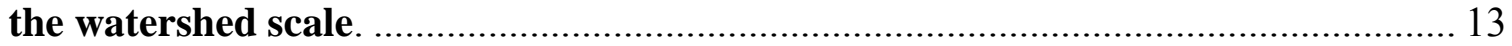

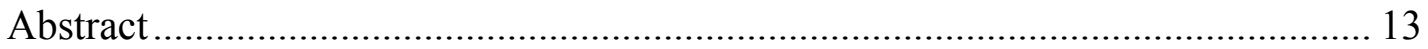

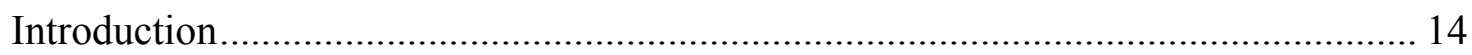

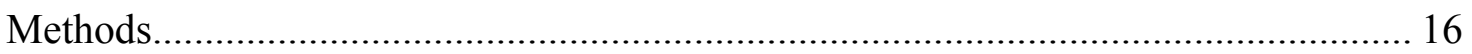

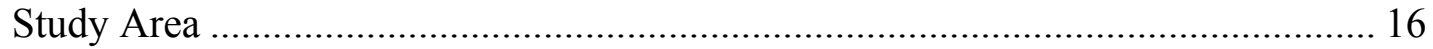

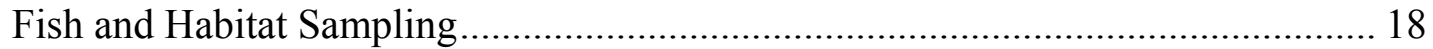

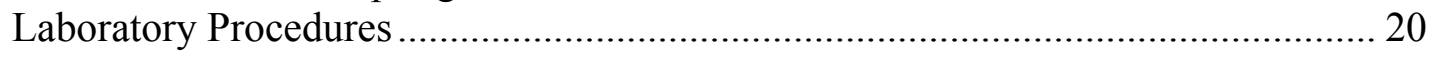

Estimates of Consumption and Daily Ration ................................................. 20

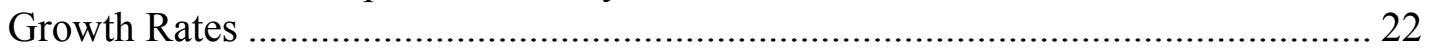

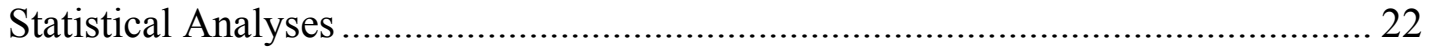

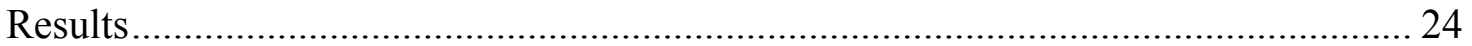

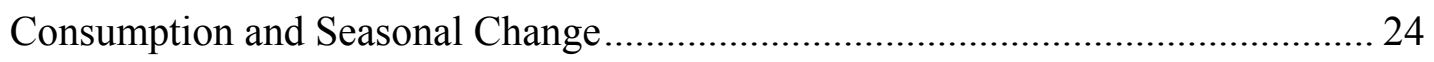

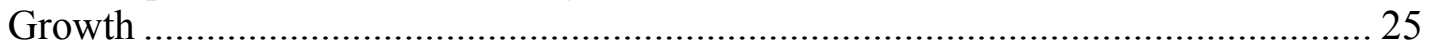

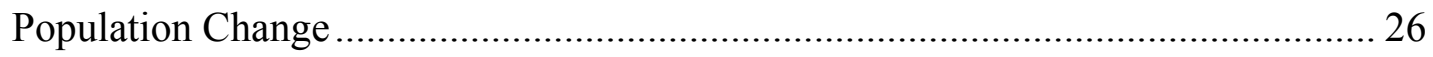

Consumption by Site and Population Density ….................................................. 26

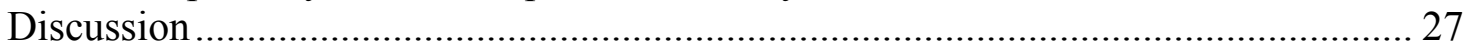

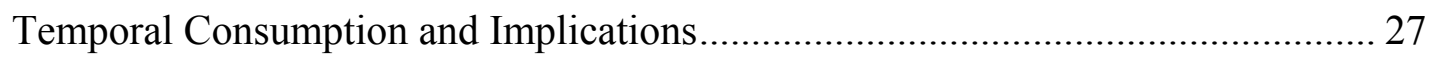

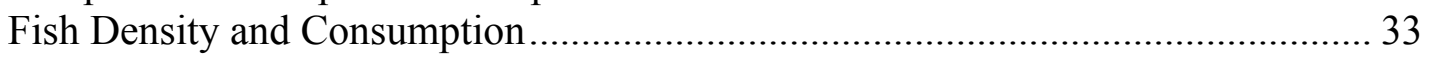

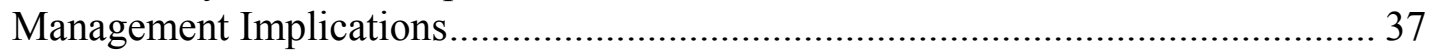

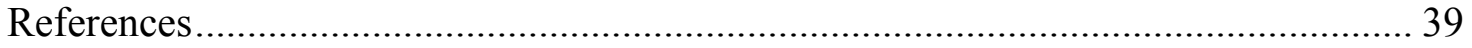

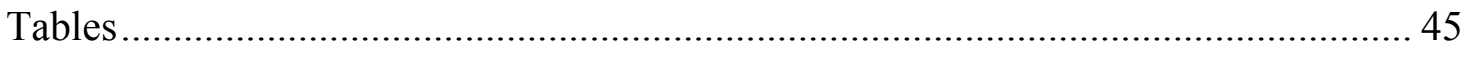

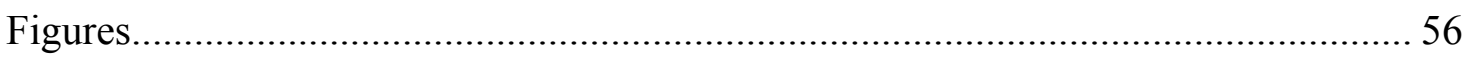

Chapter 3: Temporal change in successful feeding of an Appalachian brook trout

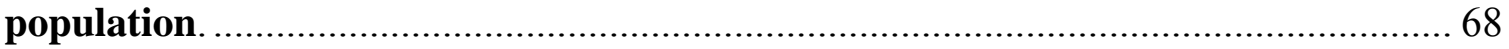

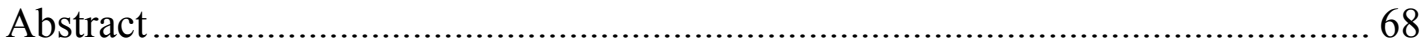

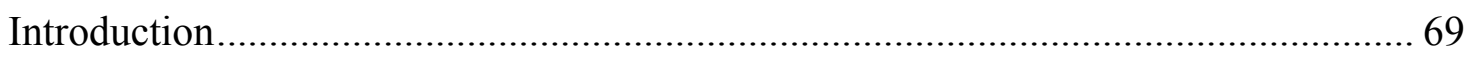

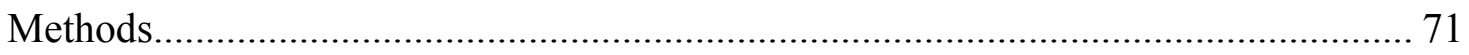

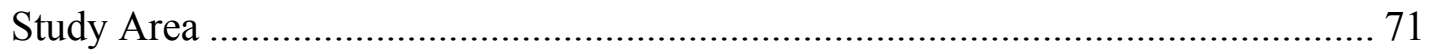

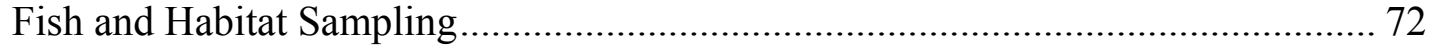

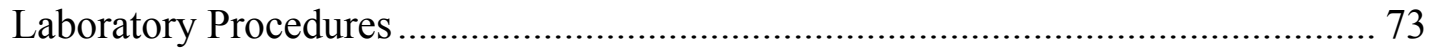

Estimates of Consumption and Daily Ration ................................................... 74

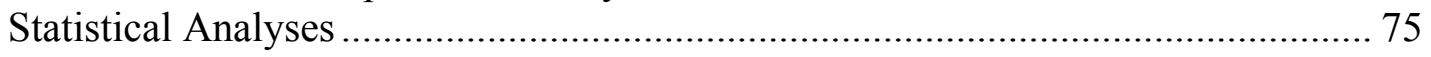

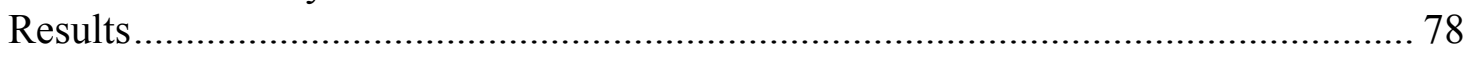

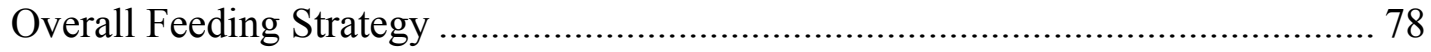

Strategy and Consumption in Relation to Maintenance Ration .............................. 80 


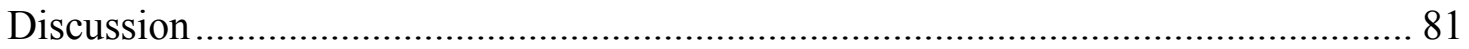

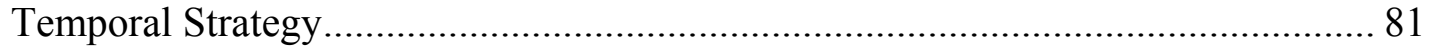

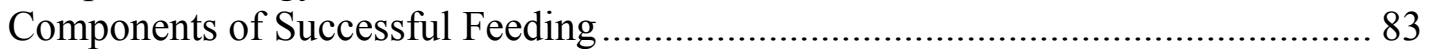

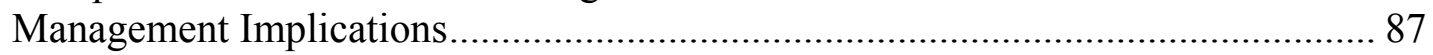

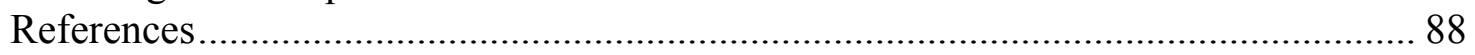

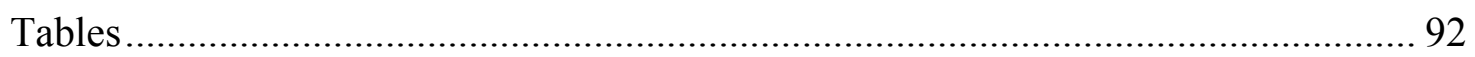

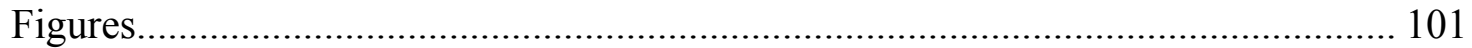

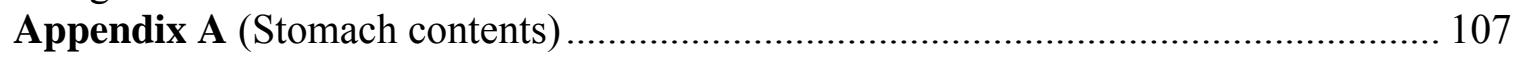

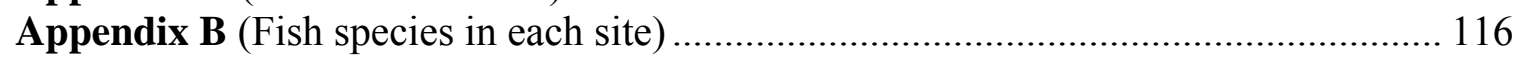

Vitae............................................................... 117 


\section{Chapter 1: Literature Review}

Quantitative surveys of fish diets allow insight into the ecological processes of

fishes. Measurement of dietary trends may provide insight into trophic cascades (Vander Zanden at al. 2000), niche specialization of individuals within a species (Bridcut and Giller 1995, Beaudoin et al. 1999), and help explain the causal mechanisms governing the distribution of organisms at the watershed scale (Nakano et al. 1999). Examining how seasonal change influences prey availability can indicate when fish experience feeding related stress or population change (Ensign et al. 1990). Such stressful feeding conditions may be affected by environmental variables, such as watershed position, annual variations in prey availability, prey and predator density, specific habitat features, and water temperature. Temporal changes in diet composition and how they relate to other physical conditions may be particularly important in species where food resources are consistently limited during certain seasons.

Appalachian brook trout (Salvelinus fontinalis) represent one such species where food resources are often limited. Multiple studies of salmonid feeding patterns in southern and central Appalachia have revealed that feeding during the summer months may be particularly low (Cada et al. 1987, Ensign et al. 1990, Sweka 2003), although food limitation may not be limited to summer alone (Sweka and Hartman 2001). Brook trout populations in Appalachia have been reduced due to historic and recent human activity, such as uncontrolled logging, acidic precipitation, acid mine drainage, introduced species, and overfishing (Marscall and Crowder 1996). As a result, the effects of natural periodic episodes of food resource depletion may be compounded due to local anthropogenic impacts. This review focuses on the quantitative and qualitative lotic 
salmonid feeding ecology that likely governs Appalachian brook trout populations with an emphasis on processes that affect feeding rates at the watershed scale.

\section{Seasonal Change}

Among the most important variables that affect feeding rates of lotic salmonids is temporal change. The warmer seasons are considered the most productive seasons for stream dwelling salmonids, as temperatures are conducive to efficient gastric evacuation and insect activity is high (Power 1980, Neveu 1999). However, the summer months may present poor feeding conditions for lotic salmonids, as flow decreases and insect activity drops (Cada et al. 1987, Ensign et al. 1990). During particularly dry summers, habitat related stressors may compound the effects of low feeding rates (Hakala and Hartman 2004). Salmonids employ a range of strategies in order to survive summer, such as exploiting disproportionately productive habitat units (de Crespin de Billy 2002) and targeting terrestrial invertebrate prey (Kawaguchi and Nakano 2001, Sweka 2003). Nevertheless, food limitation may not be limited to summer alone, and lotic salmonids may utilize other strategies and environmental variables to survive sparse prey availability during colder seasons.

Feeding conditions for lotic salmonids during the winter may be poor, particularly for brook trout (Cunjak and Power 1987, Sweka and Hartman 2001). The brook trout life history strategy poses a problem for fish surviving winter, as this species spawns in the fall and consequentially enters the winter season with reduced energy stores (Hutchings 1994, Hutchings et al. 1999). Trout and salmon continue to feed and exploit disproportionately productive habitats during the winter (Cunjak 1987, LeHane et al. 2001). However, colder water temperatures during the winter reduce metabolic demands 
(Elliot 1976). Consequently, multiple surveys of different salmonid species have observed fish feeding below maintenance ration for extended periods without substantial population mortality (Cunjak 1987, Steinhart and Wurtsbaugh 2003). Brook trout do experience low feeding rates during fall and winter (Sweka and Hartman 2001). Yet winter induced physiological stress appears to be caused by acclimatization to cold temperatures near the onset of winter, and, following acclimatization, severe loss of energy reserves due to winter conditions becomes less severe (Cunjak 1988).

\section{Watershed Position}

One environmental feature that may affect feeding conditions independent of seasonal change is the position of fish in the watershed. An extensive case study of this concept involves Arctic grayling (Thymallus arcticus) in Alaska. As position in the watershed moves upstream, mean Arctic grayling size increases (Hughes and Reynolds 1994). The relationship between fish size and watershed position was found to be driven by a dominance hierarchy, where larger, more competitively dominant fish defended upstream positions and excluded smaller fish driving them into downstream reaches (Hughes 1992, Hughes 1999, Hughes 2000). The upstream positions occupied by large fish were found to be more profitable in terms of foraging and temperature quality (Hughes 2000). While this case study represents the most detailed examination relating habitat quality in terms of foraging and fish distribution in salmonids, contrasting relationships between salmonid population distribution and watershed position have been observed or suggested in other species.

All organisms, including stream-dwelling salmonids, generally distribute spatially according to one of two ways as proposed by Fretwell and Lucas (1970). One 
distribution pattern is termed ideal-free, where organisms distribute equally along a resource gradient. Here, higher densities of organisms are found where resources are abundant, and fewer organisms in areas of low resource availability. The other pattern, competitive-dominant, theorizes that dominant organisms acquire and defend territories of higher quality and competitively exclude less dominant organisms to areas of low resource availability. While the Arctic grayling example may suggest that lotic salmonids distribute according to the competitive-dominant principle, others have observed salmonids distributed according to the ideal-free theory. Bohlin et al. (1994) found a relationship between body size and watershed position in Scandanavian brown trout (Salmo trutta), where trophic resources were divided evenly along the watershed gradient. Fish were therefore considered to be distributed under ideal-free mechanisms. In a prey manipulation experiment of a headwater watershed, Nakano et al. (1999) found that the removal of an important resource (terrestrial organisms) caused lotic salmonid populations to spatially redistribute according to available resources, again suggesting an ideal-free distribution. Therefore, both distributional patterns as proposed by Fretwell and Lucas (1970) have been observed in lotic salmonid populations. Few similar studies on Appalachian brook trout have been conducted. However, increased levels of energy intake, particularly due to higher rates of piscivory, have been observed in brook trout occupying large reaches of streams at the periphery of their typical habitat (Thorne 2004). Furthermore, movement in a downstream direction has been suggested to improve foraging conditions in general (Schlosser 1995). An understanding of how brook trout employ different reaches of watersheds to obtain energy could help determine which habitats are necessary to grow and maintain populations. 


\section{Terrestrial Organisms}

Recent research suggests that in some cases terrestrial organisms may exceed aquatic prey in importance. Allan (1951) first suggested that terrestrial organisms may allow streams to carry salmonid populations greater in biomass than what aquatic prey could provide. Multiple studies in headwater watersheds in Japan have revealed that terrestrial prey organisms consistently provide more energy to trout than aquatic prey sources (Nakano et al. 1999, Kawaguchi and Nakano 2001). Further, salmonids were found to be spatially distributed based on the availability of terrestrial organisms in these systems (Nakano et al. 1999). Fish in watersheds considered largely dependent on salmon carcass nutrients in Alaska have been shown to acquire substantial energy both directly (Wipfli 1997) and indirectly (Wipfli and Gregovich 2002) from insects with no obligate aquatic phase.

Despite these findings, most diet studies of lotic salmonids have focused on aquatic prey taxonomy and compile all terrestrial organisms into one broad category (Cada et al. 1987, Forrester et al. 1994, Bridcut and Giller 1995, Mookerji et al. 2004). In some (Forrester et al. 1994, Bridcut and Giller 1995), terrestrial organisms were found to be of particular importance, yet little to no attention was given to the taxonomic detail of such organisms. When terrestrial taxonomic detail is considered, findings show that some taxa provide a disproportionate amount of energy to aquatic systems, while others may be negligible (Wipfli and Gregovich 2002). Such findings have implications for stream management, as active manipulation of the riparian zone may affect terrestrial insect communities and consequentially affect the aquatic community and stream fishes (Nakano and Kawaguchi 2001, Wipfli and Gregovich 2002, Allan et al. 2003). 
The importance of terrestrial organisms to salmonids in Appalachia has received little attention until recently, though such prey items may be of particular importance. Sweka (2003) found that terrestrial organisms may play a large role in shaping Appalachian brook trout growth rates throughout certain times of the year. Others have concurred with this finding, suggesting terrestrial organisms act as important energy sources for salmonids in the Appalachians (Cada et al. 1987, Ensign et al. 1991, Thorne 2004). In these studies, the taxonomic specifics of terrestrial organisms were not reported. Yet in a study of central Appalachian brook trout, Webster and Hartman (2005) found differing levels of importance for various terrestrial prey organisms. Watersheds containing brook trout in central Appalachia are low in productivity, as they are typically headwater systems dependent on allochthonous energy input from the surrounding forest ecosystems (Vannote et al. 1980, Schlosser 1991, Schlosser 1995). Therefore, the conditions for stream fishes in Appalachia are likely similar to other systems of low productivity, such as streams in Japan and Alaska, where terrestrial energy sources have received much research attention.

\section{Feeding Strategy and Prey Diversity}

Lotic salmonids employ a diverse range of feeding strategies across the environments in which they occur. In some watersheds, lotic salmonids may use a small number of prey organisms over the course of the year. For instance, different species of trout may exploit as few as three to five genera of prey organisms over the course of a year in tailwater reaches of rivers (McKinney and Speas 1991, Odenkirk and Estes 1991) or Arctic environments (Steingrimsson and Gislason 2002). More commonly, however, lotic salmonids employ a highly generalist strategy and exploit a large number of prey 
taxa (Allen 1981, Hubert and Rhodes 1989, Angradi and Griffith 1990, Nielsen 1992, Forrester et al. 1994, Bridcut and Giller 1995, Amundsen et al. 1996, Mookerji et al. 2004). Due to this commonly observed generalist strategy, some diet studies have placed emphasis on prey diversity (Bridcut and Giller 1995), though defining 'high' diversity to allow comparison among studies has yet to be resolved (Chipps and Garvey in press).

Brook trout in eastern North America seem to employ a generalist feeding strategy. Sweka (2003) and Forrester et al. (1994) both reported a broad range of taxa in brook trout stomachs during the warmer seasons. However, during the summer, multiple studies of Appalachian salmonids have shown that prey availability of particular taxa decreases and stomach content consequentially declines during this time of year (Cada et al. 1987, Ensign et al. 1990, Sweka 2003). Despite cold temperatures during the winter, active feeding on multiple taxa has been observed in brook trout during this season (Cunjak and Power 1987, Sweka and Hartman 2001). Due to the broad environmental variability in seasons experienced by brook trout and generalist feeding pattern they employ, a detailed understanding of what specific prey taxa are important and when could help improve management and ecological understanding of the species.

\section{Objectives}

The current study aimed to quantitatively and descriptively assess brook trout diet across a range of seasons and watershed positions in a central Appalachian watershed. Salmonid diets may be influenced by a host of variables as described above, and the current study attempted to address as many as possible. An understanding of the multiple factors influencing the amount of energy brook trout are capable of deriving from the environment could help influence future management decisions and thus assist in 
protecting the species. Specifically, goals of this study included: (1) determining the seasonal patterns in brook trout consumption and how it relates to maintenance ration and growth rates, (2) discerning if population density or watershed position plays a role in energy intake, (3) describing brook trout feeding strategy with an emphasis on aquatic and terrestrial resource use, and (4) identifying any disproportionately important food items that may be necessary in carrying brook trout populations through periods of stress. 


\section{References}

Allan, J. D. 1981. Determinants of diet of brook trout (Salvelinus fontinalis) in a mountain stream. Canadian Journal of Fisheries and Aquatic Science 38: 184-192.

Allan, J. D., Wipfli, M. S., Caouette, J. P., Prussian, A., and Rodgers, J. 2003. Influence of streamside vegetation on inputs of terrestrial invertebrates to salmonid food webs. Canadian Journal of Fisheries and Aquatic Science 60: 309-320.

Allan, K. R. 1951. The Horowiki stream: a study of a trout population. The New Zealand Marine Department of Fisheries Bulletin 10: 1-231.

Amundsen, P. A., Gabler, H. M. and Staldvik, F. J. 1996. A new approach to graphical analysis of feeding strategy from stomach contents data- modifications of the Costello (1990) method. Journal of Fish Biology 48: 607-614.

Angradi, T. R. and Griffith, J. S. 1990. Diel feeding chronology and diet selection of rainbow trout (Oncorhynchus mykiss) in the Henry's Fork of the Snake River, Idaho. Canadian Journal of Fisheries and Aquatic Science 47: 199-209.

Beaudoin, C. P., Tonn, W. M., Prepas E. E. and Wassenaar, L. I. 1999. Individual specialization and trophic adaptability of northern pike (Esox lucius): an isotope and dietary analysis. Oecologia 120: 386-396.

Bohlin, T., Dellefores, C., Faremo, U. and Johlander, A. 1994. The energetic equivalence hypothesis and the relation between population density and body size in stream-living salmonids. The American Naturalist 143: 478-493.

Bridcut, E. E. and Giller, P. S. 1995. Diet variability and foraging strategies in brown trout (Salmo trutta): an analysis from subpopulations to individuals. Canadian Journal of Fisheries and Aquatic Science 52: 2543-2552.

Cada, G. F., Loar, J. M. and Sale, M. J. 1987. Evidence of food limitation of rainbow and brown trout in southern Appalachian soft-water streams. Transactions of the American Fisheries Society 116: 692-702.

Chipps, S. R. and J. E. Garvey. In press. Assessment of food habits and feeding patterns. Edited by M. Brown. Analysis and Interpretation of Freshwater Fisheries Data. American Fisheries Society, Bethesda, Maryland. pp xx-yy.

Cunjak, R. A. 1988. Physiological consequences of overwintering in streams: the cost of acclimization? Canadian Journal of Fisheries and Aquatic Science 45: 443-452.

Cunjak, R. A. and Power, G. 1987. The feeding and energetics of stream-resident trout in winter. Journal of Fish Biology 31: 493-511. 
De Crespin de Billy, V., Dumont, B., Lagarrigue, T., Baran, P., and Statzner, B. 2002. Invertebrate accessibility and vulnerability in the analysis of brown trout (Salmo trutta L.) summer habitat suitability. River Research and Applications 18: 533-553.

Elliot, J. M. 1976. The energetics of feeding, metabolism, and growth of brown trout (Salmo trutta L.) in relation to body weight, water temperature, and ration size. Jounal of Animal Ecology 45: 923-948.

Ensign, W. E., Habera, J. W., and Strange, R. J. 1989. Food resource competition in southern Appalachian brook and rainbow trout. Proceedings from the Annual Conference of Southeastern Assosiation of Fisheries and Wildlife Agencies 43: 239-247.

Ensign, W. E., Strange, R. J., and Moore, S. E. 1990. Summer food limitation reduces brook and rainbow trout biomass in a southern Appalachian stream. Transactions of the American Fisheries Society 119: 894-901.

Forrester, G. E., Chace, J. G., and McCarthy, W. 1994. Diel and density-related changes in food consumption and prey selection by brook charr in a New Hampshire stream. Environmental Biology of Fishes 39: 301-311.

Fretwell, S. D. and Lucas, H. L. 1970. On territorial behavior and other factors influencing habitat selection in birds. Acta Biotheoretica 19: 16-36.

Hakala, J. P. and Hartman, K. J. 2004. Drought effect on stream morphology and brook trout (Salvelinus fontinalis) populations in forested headwater streams. Hydrobiologia 515: 203-213.

Hubert, W. A. and Rhodes H. A. 1989. Food selection by brook trout in a subalpine stream. Hydrobiologia 178: 225-231.

Hughes, N. F. 1999. Population processes responsible for larger-fish-upstream distribution patterns of Arctic grayling (Thymallus arcticus) in interior Alaskan runoff rivers. Canadian Journal of Fisheries and Aquatic Science 56: 2292-2299.

Hughes, N. F. 1992. Ranking of feeding positions by drift-feeding Arctic grayling (Thymallus arcticus) in dominance hierarchies. Canadian Journal of Fisheries and Aquatic Science 49: 1994-1998.

Hughes, N. F. 2000. Testing the ability of habitat selection theory to predict interannual movement patterns of a drift-feeding salmonid. Ecology of Freshwater Fish 9: 4-8.

Hughes, N. F. and Reynolds, J. B. 1994. Why do Arctic grayling (Thymallus arcticus) get bigger as you go upstream? Canadian Journal of Fisheries and Aquatic Science 51: 21542163.

Kawaguchi, Y. and Nakano, S. 2001. Contribution of terrestrial invertebrates to the annual resource budget for salmonids in forest and grassland reaches of a headwater stream. Freshwater Biology 46: 303-316. 
Marscall, E. A. and Crowder. L. B. 1996. Assessing population responses to multiple anthropogenic effects: a case study with brook trout. Ecological Applications 6: 152-167.

McKinney, T. and Speas, D. W. 2001. Observations of a size-related asymmetries in diet and energy intake of rainbow trout in a regulated river. Environmental Biology of Fishes 61: $435-444$.

Mookerji, N., Weng, Z., and Mazumder, A. 2004. Food partitioning between coexisting Atlantic salmon and brook trout in the Sainte-Marguerite River ecosystem, Quebec. Journal of Fish Biology 64: 680-694.

Nakano, S., Miyasaka, H., and Kuhara, N. 1999. Terrestrial-aquatic linkages: riparian arthropod inputs alter trophic cascades in a stream food web. Ecology 80: 2435-2441.

Neveu, A. 1999. Feeding strategy of the brown trout (Salmo trutta L.) in running water. Edited by J. L. Bagliniere and G. Maisse. Biology and Ecology of the Brown and Sea Trout. Springer, Chichester, UK. pp 91-113.

Nielsen, J. L. 1992. Microhabitat-specific foraging behavior, diet, and growth of juvenile coho salmon. Transactions of the American Fisheries Society 121: 617-634.

Odenkirk, J. S. and R. D. Estes. 1991. Food habits of rainbow trout in a Tennessee tailwater. Proceedings from the Annual Conference of Southeastern Assosiation of Fisheries and Wildlife Agencies 45: 451-459.

Power, G. 1980. The brook charr, Salvelinus fontinalis. Pages 141-202 Edited by E. K. Balon. Charrs: Salmonid fishes of the genus Salvelinus. Dr. W. Junk Publishers, The Hague.

Schlosser, I. J. 1995. Critical landscape attributes that influence fish population dymanics in headwater streams. Hydrobiologia 303: 71-81.

Schlosser, I. J. 1991. Stream fish ecology: a landscape perspective. BioScience 41: 704712.

Steingrimsson, S. O. and Gislason, G. M. 2002. Body size, diet and growth of landlocked brown trout, Salmo trutta, in the subarctic River Laxa, North-East Iceland. Environmental Biology of Fishes 63: 417-426.

Steinhart, G. B. and Wurtsbaugh, W. A. 2003. Winter ecology of Kokanee: implications for salmon management. Transactions of the American Fisheries Society 132: 1076-1088.

Sweka, J. A. 2003. Aquatic-terrestrial linkages in Appalachian streams: influence of riparian inputs on stream habitat, brook trout populations, and trophic dynamics. Ph.D. dissertation, Division of Forestry, West Virginia University, Morgantown, WV. 
Sweka, J. A. and Hartman, K. J. 2001. Fall and winter brook trout prey selection and daily ration. Procedures from the Annual Conference of Southeastern Assosiation of Fisheries and Wildlife Agencies 55: 8-22.

Thorne, D. W. 2004. Spatial and seasonal variation in brook trout diet, growth, and consumption in a complex Appalachian watershed. M.Sc. thesis, Division of Forestry, West Virginia University, Morgantown, WV.

Vander Zander M. J., Shuter B. J., Lester, N. P., and Rasmussen, J. B. 2000. Within- and among-population variation in the trophic position of a pelagic predator, lake trout (Salvelinus namaycush). Canadian Journal of Fisheries and Aquatic Science 57: 725-731.

Vannote, R. L., Minshall, G. W., Cummins, K. W., Sedell, J. R., and Cushing, C. E. 1980. The river continuum concept. Canadian Journal of Fisheries and Aquatic Science 37: $130-137$.

Webster, J. J. and Hartman, K. J. 2005. The role of terrestrial invertebrates in allopatric brook trout headwater streams in the central Appalachian mountains. Journal of Freshwater Ecology 20: 101-107.

Wipfli, M. S. 1997. Terrestrial invertebrates as salmonid prey and nitrogen sources in streams: contrasting old-growth and young-growth riparian forests in southeastern Alaska, USA. Canadian Journal of Fisheries and Aquatic Science 54: 1259-1269.

Wipfli, M. S. and Gregovich, D. P. 2002. Export of invertebrates and detritus from fishless headwater streams in southeastern Alaska: implications for downstream salmonid production. Freshwater Biology 47: 957-969. 


\section{Chapter 2: Temporal variation in the energy intake of Appalachian brook trout at the watershed scale.}

Abstract- Salmonids often experience prolonged periods of poor feeding conditions with consequences at the individual and population level. Feeding intensity may be related to seasonal change, habitat and watershed variables, or fish density. This study examined the consumption and growth rates of Appalachian brook trout (Salvelinus fontinalis) across a range of seasons and stream sizes within the same watershed. Consumption varied significantly with seasonal change. Energy intake was highest during the spring and late summer, reduced from mid-summer to fall, and lowest during winter. Estimates of maintenance ration provided insight into whether or not brook trout were obtaining sufficient energy to maintain weight; consumption significantly exceeded maintenance ration during the spring, early summer, and fall. Growth rates were significantly positively correlated with consumption estimates, with positive growth observed only when the time interval ended during a spring or early summer sampling period. Population change was significantly positively correlated with corresponding consumption estimates. Significant differences in consumption between stream sizes were observed, with fish in downstream reaches obtaining more energy than fish upstream. During the summer and fall months, the population density of large fish was negatively correlated with mean consumption in a given site. Findings in this study concur with others that Appalachian brook trout are energetically stressed through the summer, though mean consumption was significantly lower than maintenance ration only during the winter. Downstream habitat appeared to be underutilized for energy exploitation by the total population. Further, the negative relationship between trout 
density and consumption during the summer suggests that Middle Fork brook trout do not distribute with resource availability at the watershed scale.

\section{Introduction}

Salmonids commonly occur in watersheds of low productivity, often with ecological consequences at the individual and population level. In temperate mountainous regions, trout typically occupy headwater reaches of watersheds. These streams derive nearly all energy from allochthonous input from the surrounding terrestrial ecosystem and are naturally low in productivity (Vannote et al. 1980). As a result, sparse food resources may often be capable of shaping population dynamics through emigration of fish in search of food resources (Petty et al. 2005). Energy intake also determines how an individual fish grows (Elliot 1976, Filbert and Hawkins 1995). Within low productivity headwater systems, growth has been correlated with energy intake at the reach scale due to differences in the quality and quantity of food at different reaches (Kawaguchi and Nakano 2001, Thorne 2004). Despite the obvious importance of energy intake in fish populations, little attention has been paid to temporal and spatial trends in consumption rates of wild salmonids (Neveu 1999). Those that have, found salmonids endure sustained periods of energy intake below maintenance ration (Cada et al. 1987, Cunjak and Power 1987, McKinney and Speas 2001, Sweka 2003).

Due to the sparse availability of food resources, the distributional trends of lotic salmonids at the watershed scale may play a role in how energy is obtained and allocated. Hughes and Reynolds (1994) and Hughes (1999) observed distributional patterns of arctic grayling (Thymallus arcticus) where fish size increased as the position in the 
watershed moved upstream. Competitive dominance of larger individuals was the driving force in this pattern, as larger individuals assumed upstream positions where both temperature and concentrations of food were optimal (Hughes 2000). As a result, both body size and energy intake was correlated with position in the watershed. Similar trends have been observed in other salmonids, such as the brown trout (Salmo salar) (Bohlin et al. 1994). Although some studies show that feeding varies at the microhabitat scale (De Crespin de Billy et al. 2002), the current study was concerned with variation at the watershed scale.

Appalachian brook trout (Salvelinus fontinalis) occupy low productivity headwater systems (Schlosser 1995) and are considered vulnerable to anthropogenic impacts (Marscall and Crowder 1996). Similar to salmonids in other regions, Appalachian brook trout likely experience severe limitations in food availability during certain seasons. Multiple studies have either suggested (Cada et al. 1987) or shown (Ensign et al. 1990, Sweka 2003, Thorne 2004) that Appalachian salmonid populations experience limitations in energy intake. Specifically, these fish may spend a significant proportion of the summer months obtaining daily rations less than what is required to maintain a constant body weight (Cada et al. 1987, Sweka 2003). Brook trout energy intake in central Appalachia may be related to watershed position, as piscivory rates increase in larger order reaches of streams (Thorne 2004). Appalachian brook trout have been subjected to multiple historic and ongoing anthropogenic effects, such as uncontrolled logging, acidic precipitation, introduced species, overfishing, and acid mine drainage (Marscall and Crowder 1996, Clark and Rose 1997). Such detrimental effects 
may compound the consequences of poor feeding conditions during certain seasons to create population instability and/or decline.

A detailed understanding of how temporal and spatial change affects the amount of energy consumed by brook trout at the watershed scale could help determine how brook trout populations react to variations in feeding conditions. Temporal variation in consumption likely affects the growth of individual fish, recruitment of fish into larger size classes, and mortality when food limitation is coupled with environmental extremes. Further, position in the watershed may affect how much energy a fish derives from the environment. Identifying how seasonal change and watershed position interact to affect energetic input could help managers prioritize specific habitat units and foresee periods of feeding related stress. Objectives of this study were to: (1) determine the seasonal patterns in brook trout consumption and how it relates to maintenance ration, (2) establish how growth relates to energy intake over the course of a year and (3) discern if population density or watershed position plays a role in energy intake.

\section{Methods}

\section{Study Area}

The study was conducted within the Middle Fork watershed, a north flowing tributary of the Tygart River in the central Appalachian Mountains of Randolph County, West Virginia. The majority of land cover within the watershed is that of secondary growth hardwood deciduous forest. All sites in the study are located in the southernmost extent of the watershed (Figure 1) and are of low order and high gradient (see Table 1 for descriptions of each site). Nine-200 m sites were selected to encompass a range of stream sizes and were based on a number of criteria: each site contained a resident brook 
trout population, consistently held age-0 brook trout (indicating water quality was sufficient for spawning) and was devoid of fish barriers between other sites. Temperature regimens in these reaches are suitable for trout; temperature rarely exceeded $20^{\circ} \mathrm{C}$ through the duration of the study. The West Virginia Division of Natural Resources and the West Virginia Department of Environmental Protection have actively added limestone sand to riparian areas of streams within the watershed to remediate the effects of acid precipitation and acid mine drainage in the Middle Fork since the 1990's (WVDNR 2001). This process is commonly used in the region and successfully increases $\mathrm{pH}$, restores fish communities, and increases invertebrate abundance (Clayton et al 1998), though invertebrate productivity and diversity may not reach pre-acidification levels following treatment (McClurg 2004). Some sites selected in this study were not actively treated with lime (Table 1); however, each site without a limestone treatment retained the ability to support brook trout spawning and carry fish populations. In order to quantify water quality in each site, a sample of water was taken in February, May, July, and October 2004 and tested at a laboratory for $\mathrm{pH}$ and alkalinity. The means of both measurements were calculated for each site based on the four seasonal measurements (Table1); this calculation provided an estimate of mean water quality across seasons.

Fish diversity differed across sites, but was typical of Appalachian headwater systems. The number of species encountered increased with stream size. In nearly all sites fish fauna was dominated by brook trout and mottled sculpin (Cottus bairdi). Other fish sampled include blacknose dace (Rhynichthys obtusis), longnose dace ( $R$. cataractae), creek chub (Semotilus atromaculatus), white sucker (Catostomus 
commersoni), northern hogsucker (Hypentelium nigricans), and fantail darter (Etheostoma flabellare).

\section{Fish and Habitat Sampling}

Fish sampling occurred eleven times over the course of two years (Table 2). Sampling was conducted between 0800 and 1600 hours and the order of sites to sample was randomly chosen during each day. A three-pass depletion electrofishing procedure (Platts and Nelson 1988) was used in order to estimate fish populations within the $200 \mathrm{~m}$ section. Before sampling, block nets were placed at the top and bottom of each section to restrict fish movement in or out of sections during sampling. Sampling teams used an electrofishing unit (Smith-Root, DC, $60 \mathrm{hz}, 500-750 \mathrm{~V}$, Vancouver, WA) and dip nets to capture fish.

Following collection, fish were processed at a streamside station. All fish were immobilized with a clove oil and $95 \%$ ethanol solution. Brook trout were weighed to the nearest $0.5 \mathrm{~g}$, and total length was taken to the nearest $\mathrm{mm}$. A subset of 10 brook trout per site per month was chosen for stomach content removal. Only fish $>110 \mathrm{~mm}$ fork length were considered eligible for gut content removal due to gear restrictions; the gape of fish below this size was usually about the same size of the flushing tube diameter (7 $\mathrm{mm})$. This size class generally represented age- 1 and older fish as is apparent in length frequency histograms (Figure 2). An attempt was made to collect an equal range of fish sizes to analyze for gut content at each site. Stomach contents were removed by directing a constant flow of stream water into the foregut until all items had been apparently collected (Twomey and Giller 1990). Gut items were filtered with a $250 \mu \mathrm{m}$ sieve and transferred to $95 \%$ ethanol. This process of collecting stomach contents has proven 
effective (Light et al. 1983) and analysis with the gear used in this study has found that the technique is acceptably efficient (Sweka 2003).

During May 2004, each fish over 100 mm fork length was given a unique colorcoded mark using Visible Implanted Flourescent Elastomer (Northwest Marine Technology, Shaw Island, WA) tags for subsequent identification and growth estimation. Following an analysis of recapture success, tagging was carried out every sampling period starting in December 2004 and ending in June 2005. Marks of up to seven colored tags were injected into the caudal and dorsal fins of trout, allowing the identification of individual fish in subsequent months. All fish other than trout were counted and weighed. Each fish was allowed to recover from the clove oil treatment and returned to the stream reach within two hours. A sample of 10 trout were randomly collected from sites, frozen, and kept for analysis of dry weight during select sampling periods (see Table 3). Estimates of brook trout dry weights were needed in order to estimate fish energy density, a necessary component of bioenergetics modeling.

In order to determine if habitat or fish density variables were related to consumption at the watershed scale, habitat variables were calculated at each site. Habitat sampling was conducted during base flow on August $17^{\text {th }}, 2005$ according to a modified version of Dolloff et al. (1997). Variables were directly measured, rather than estimated, on each $200 \mathrm{~m}$ reach of stream. Reaches within each site were classified as riffle or pool and the length of each unit was measured. Within each habitat unit, specific measurements were taken along a linear transect perpendicular to the stream, including wetted width, bankful width, and depth ( 3 points per transect). The number of times a transect was measured within a habitat unit depended on the length of the unit, with 
measurements made approximately every $20 \mathrm{~m}$ in riffles and every $2 \mathrm{~m}$ in pools. The basin area $\left(\mathrm{km}^{2}\right)$ of each site was determined using coordinates derived from a global positioning system at the midpoint of each site and calculated using GIS.

\section{Laboratory Procedures}

All prey items were identified to the Family level or the lowest taxonomic classification possible (Merrit and Cummins 1996, Borror et al. 1989). Extremely small $(<0.5 \mathrm{~mm})$ organisms or organisms partially destroyed beyond identification to Family were classified to Order. The lengths of prey items were measured via an ocular micrometer to the nearest $0.1 \mathrm{~mm}$; when lengths were unavailable head capsules widths were measured to the nearest $0.1 \mathrm{~mm}$. Crayfish (Cambarus bartonii) carapace lengths were measured rather than head capsule width or body length. The dry mass of each organism was estimated using published length- or head width-dry mass equations, with the exception of crayfish where a carapace-dry mass equation was used (Sample et al. 1993, Benke et al 1999, Johnston and Cunjak 1999, Sabo et al. 2002). Vertebrate food items, such as frogs, salamanders, and fish were dried at a temperature of $60^{\circ} \mathrm{C}$ for 48 -hr to calculate dry weight. Frozen brook trout were thawed, weighed to the nearest $0.1 \mathrm{~g}$, and dried at a temperature of $60^{\circ} \mathrm{C}$ for 72 -hr for dry weight and energy density analysis.

\section{Estimates of Consumption and Daily Ration}

Estimates of consumption and maintenance ration were calculated in order to determine seasonal and spatial variation in energy intake. Comparing estimated consumption to maintenance ration suggests whether or not fish are obtaining enough energy to maintain body weight. Estimated maintenance rations (EMR, in Joules per 
gram fish wet weight per day) were calculated based on a bioenergetics model for brook trout (Hartman and Sweka 2001) and used fish weight, fish energy density, and observed water temperature as variables. Maintenance ration was determined by calculating the energy required to maintain zero growth over the course of a day. Energy densities were calculated from either observed mean energy density in collected fish using a dry weightenergy equation for Salmonidae (Hartman and Brandt 1995) or interpolated from energy densities taken before and after a given collection period (see Table 3 for observed trout energy densities). Mean fish energy density was assumed to be equal across sites during a given month. Consumption estimates were calculated based on a model proposed by Eggers (1977). Each prey item was converted to energy using published dry weightenergy equations (Table 4, Cummins and Wuycheck 1971), and the total energy in the gut was summarized for each fish.

The total energy intake was multiplied by the brook trout gastric evacuation rates (based on temperature, Sweka et al. 2004) and divided by fish weight to calculate an observed consumption value $\left(\mathrm{J} \mathrm{g}^{-1}\right.$ fish $\left.\mathrm{h}^{-1}\right)$ as suggested by Eggers (1977). This estimate was multiplied by 24 to convert it to a daily ration. The mean daily consumption estimates in this study were based on stomach contents obtained during the daylight hours only. Though daily consumption typically requires estimates of feeding activity across a diel cycle (Bowen 1996), multiple studies of indigenous brook trout feeding trends revealed no significant diel pattern in multiple diet variables (Forrester et al. 1994, Sweka 2003, Mookerji et al. 2004). Further, the evacuation rate of brook trout has proven to be low relative to other salmonids (Sweka et al. 2004), meaning food items remain in the gut long after they have been ingested. Thus the current study made the 
assumption that a measurement of diet during daylight hours provided sufficient data to calculate mean feeding conditions for the corresponding season.

\section{Growth Rates}

Growth estimates were calculated in order to quantify temporal trends and compare growth to consumption variables. Mark-recapture analysis of tagged individuals provided estimates of growth over the course of the study. Growth was calculated from the following equation (from Jensen 1990):

$$
\mathrm{G}=100 *\left(\ln \mathrm{X}_{\mathrm{t}}-\ln \mathrm{X}_{0}\right) / \Delta \mathrm{t}
$$

where $\mathrm{G}$ is daily growth, $\mathrm{X}_{\mathrm{t}}$ is the final weight at time $\mathrm{t}, \mathrm{X}_{0}$ is the initial weight, and $\Delta \mathrm{t}$ is the amount of time elapsed between capture events in days. Size-adjusted growth $\left(\mathrm{G}_{\mathrm{i}}\right)$ :

$$
\mathrm{G}_{\mathrm{i}}=\mathrm{G} / \ln \mathrm{X}_{0}
$$

was also analyzed to determine if fish size affected growth rates. All fish obviously missing an individual mark were removed from growth analyses to prevent inaccurate growth increments from distorting patterns. Growth intervals were considered between consecutive sampling events only for the purpose of simplification. For example, if a fish was caught in June 2004 and August 2004, but not July 2004, growth rates were not calculated for that particular fish.

\section{Statistical Analyses}

Consumption estimates were square-root transformed to approximate normality and were analyzed using repeated measures analysis of variance (ANOVA) to test for differences between months. Duncan's multiple range test was used to determine specific differences once overall differences had been established. A two-way pairwise t- 
test was performed on mean maintenance ration and observed consumption for each month to determine if fish were meeting maintenance requirements. Differences in growth rates between months were tested for using repeated measures ANOVA and Duncan's multiple range post-hoc test. Early analyses showed that each month could be classified into one of three broad seasons based on similarities in temperature and consumption (Table 5).

Population estimates were calculated in order to determine population change, estimate fish density, and allow comparison of consumption and population variables. Population estimates of all fish, and fish eligible for gastric lavage, were calculated for each stream using the Zippin model in program CAPTURE (White et al. 1982). Estimates of the population of all reaches combined were calculated by adding the populations and standard errors of each reach (Mood et al.1974). If less than 30 fish were captured then the actual number of fish caught was substituted for an estimate (Riley and Fausch 1992). Fish density per site was calculated as the population estimate divided by the wetted area $\left(\mathrm{m}^{2}\right)$ of base flow. For analysis of consumption by site, each site was placed into one of three classes (upstream, midstream or downstream) based on similarities in basin area, trout density, wetted width, and fish species present (see Table 2). Differences in mean square-root transformed consumption across stream classes within each season were tested using ANOVA and Duncan's repeated measures test posthoc. Fish size and temperature were included in the ANOVA model; thus site type and temperature where considered when exploring differences in consumption between site classes. If site class did influence consumption, stepwise multiple regression was performed on mean consumption per site by habitat and density variables to determine if 
any variables were significantly correlated. Non-linear relationships were also explored to test for best-fit during these analyses by plotting both original and log-transformed variables. Further, Chi-square analysis was performed on diet composition by site class within each season to determine if differences in resource exploitation existed between site classes. For this analysis, prey organisms were organized into nine categories based on taxonomy. Site types with no significant differences within a season were treated as groups.

\section{Results}

\section{Consumption and Seasonal Change}

Brook trout consumption $\left(\mathrm{J} \mathrm{g}^{-1}\right.$ fish $\left.\mathrm{d}^{-1}\right)$ varied significantly throughout the year. Consumption estimates were linked to seasonal change with significant differences among months (F-value 23.84, $\mathrm{df}=10, \mathrm{p}<0.0001$, Table 5). Mean consumption was significantly highest during the spring (May/June 2004 and 2005), lowest during late winter (March 2004 and 2005), and intermediate during the summer and fall months (Figure 3). Differences in mean consumption values between winter and summer/fall months were occasionally statistically significant. Within a designated season, significant differences occurred between June and May of both years (Table 5).

During certain months, mean consumption differed significantly from the corresponding mean estimated maintenance ration (Figure 3 and Table 6). Whether or not a significant difference was observed was linked to seasonal change. Mean consumption during all spring months was significantly higher than maintenance ration. Only one significant difference was observed between consumption and maintenance ration during the summer or fall (September 2004); means of EMR and consumption 
were not significantly different during all other months within these seasons.

Maintenance ration estimates were significantly higher than mean observed consumptions for both March samples.

Although comparisons between consumption and maintenance ration suggested that fish were meeting metabolic demands, $<50 \%$ of fish were observed feeding above maintenance ration throughout a majority of sampling periods (Figure 4). The proportion of fish eating above maintenance ration exceeded 0.5 only during spring months. The distribution of consumption values during each season was skewed to the right, where a minority of individuals consumed a disproportionately large amount of energy relative to the mode (Figure 5).

\section{Growth}

Mean growth rates varied significantly with time $(\mathrm{F}=23.13, \mathrm{df}=8, \mathrm{p}<0.0001$, Table 7 and Figure 6). Positive growth was recorded only when the period of observation ended during a spring month. During any interval of time ending in summer, fall or winter, observed growth was either negative or near zero. No statistically significant differences between growth rates were observed between periods of time when the time interval ended in the mid to late summer, fall, or winter (Table 7). Patterns in sizecorrected growth $\left(\mathrm{G}_{\mathrm{i}}\right)$ were similar to overall growth (Table 7). Growth rates were significantly positively correlated with mean estimated consumption between months $(\mathrm{F}=6.95, \mathrm{n}=9, \mathrm{p}=0.0336$, Figure 7$)$ and estimated consumption at $\mathrm{t}_{\mathrm{n}}(\mathrm{F}=26.14, \mathrm{n}=9$, $\mathrm{p}=.0014$, Figure 7). 


\section{Population Change}

Estimates of brook trout populations across all sites varied with seasonal change (Figure 8 and Table 8). Population change was positive between late winter and early summer during both years, stable between summer and fall 2004, and negative between September 2004 and December 2004. Change in populations between December 2004 and March 2005 (over winter) was small. Shifts in population estimates were similar between all fish and fish eligible for gastric lavage (Figure 8). Fish density was significantly related to basin area during all seasons. Trout density was negatively correlated with basin area at the log-log scale for fish over $110 \mathrm{~mm}$ fork length $(\mathrm{F}=23.48$, $\mathrm{n}=26, \mathrm{p}<0.0001$, Figure 9) and all fish $(\mathrm{F}=51.14, \mathrm{n}=26, \mathrm{p}<0.0001$ Figure 9). Mean consumption during the corresponding months was significantly positively correlated with population change of all fish $(\mathrm{F}=16.14, \mathrm{n}=10, \mathrm{p}=0.0039$, Figure 10) but not fish eligible for gastric lavage $(\mathrm{F}=0.77, \mathrm{n}=10 \mathrm{p}=0.4045$, Figure 10$)$.

\section{Consumption by Site and Population Density}

During each of the three seasons, significant differences in consumption were apparent between site classes (Table 9). Fish in upstream locations consumed significantly less energy than fish occupying downstream and midstream reaches during spring and summer (Table 10). During winter, the trend shifted, with upstream consumption significantly greater than mid-order reaches, but not downstream reaches (Table 10). Because weight and temperature significantly differed across sites, these variables were included in the model. Neither negated the effects of site type during any season (Table 9). During the summer/fall season, a significant negative $\log (\mathrm{y})-\mathrm{x}$ 
relationship existed between mean consumption and large fish density $(F=19.44, n=9$, $\mathrm{p}=0.0031$, Figure 11).

Significant differences in prey exploitation were detected across sites without significant differences in mean consumption within each season (Table 11 and Figure 12). One prey type dominated energetic input during each season: Coleoptera during the spring, Lepidoptera during the summer and fall, and aquatic insect taxa during the winter. In the reach classes where mean consumption was significantly higher, the respective seasonal dominant prey types were exploited more than in reaches with lower mean consumption during each season. For example, fish in midstream and downstream reaches (where fish had significantly higher mean consumption estimates) exploited Lepidoptera larvae more heavily than those in upstream reaches during the summer and fall (Figure 12).

\section{Discussion}

\section{Temporal Consumption and Implications}

Trends inherent in this data suggest that brook trout in the upper Middle Fork River watershed experience food limitation throughout most of the year. Mean estimated daily ration fell below maintenance ration only during the winter months. Though mean consumption did not significantly differ from the corresponding maintenance ration throughout the summer and fall, less than half of the population was eating above maintenance ration during these months. The mean consumption value was elevated by a minority of particularly successful fish which were observed feeding at high rates when resources were low. Therefore, though brook trout experienced stressful feeding conditions during the summer and fall, the mean consumption of the population matched 
or exceeded maintenance ration, and coincidentally the population appeared to experience low mortality over the course of the summer. The ability of the Middle Fork River brook trout to obtain sufficient energy contrasts findings of brook trout diet studies.

Similar limitations in summer food intake have previously been inferred or observed in Appalachian salmonids, though the implications of such conditions vary from the current study. Cada et al. (1987), Ensign et al. (1990), and Thorne (2004) observed a substantial drop in the number of items and/or mean stomach content weight found in brook trout stomachs from spring to summer in populations of Appalachian salmonids. In Ensign et al. (1990), the ensuing drop in brook trout consumption was calculated as below maintenance ration. Such inefficient food resources were not observed in either summers of the current study. Sweka (2003) observed an occasional mean summer consumption estimate below maintenance ration in the same watershed as the current study; however, his study was limited to two sites and one sampling event per summer season. Thus the summer consumption values in the current study may more accurately reflect typical summer conditions for brook trout at the watershed scale.

The current study suggests that either brook trout in central Appalachia experience less severe food limitation than in southern Appalachia, or consumption is subject to annual variation. Environmental conditions for brook trout in the region may be highly variable between years due to periodic drought and flooding (Carline and McCullough 2001, Hakala and Hartman 2004). The summer seasons in the current study were not particularly severe, and it is likely that consumption values during drought years would drop below those observed in this study. Observations of a minority of fish feeding on particularly large or abundant organisms during the summer increased the 
mean consumption estimate. Thus, it is likely that central Appalachian brook trout rely on a highly generalist strategy during the summer (Chapter 3) which allows for feeding well above maintenance ration on occasion during periods of low resource availability. However, during other potentially stressful times of the year, brook trout observed in this study appeared to use temperature to survive rather than opportunistic events.

While the lowest rates of energy intake were observed during the winter, water temperatures during this time probably buffered detrimental effects of low feeding. Low water temperatures decrease the metabolic demand of salmonids (Elliot 1976). Acclimitization to decreasing water temperatures with the onset of winter may stress brook trout, particularly those fish exhausted from fall spawning (Cunjak 1988). However, once fish adjust to low temperatures, low metabolic rates decrease energetic demand and the physical consequences of low feeding may be reduced for the remainder of winter, even when fish feed below maintenance ration during such periods (Cunjak and Power 1987, Steinhart and Wurtsbuagh 2003). Results in this study concur, as the largest drop in estimated population and growth rates occurred with the onset of winter (between September and December 2004). Although this observed population drop could have been attributed to post-spawning emigration, sites less suitable for spawning (mid and downstream reaches) did not experience an increase in population. Regardless, both consumption and population estimates changed very little between December 2004 and March 2005. Therefore, the low consumption during these months did not seem to induce mortality once the apparent post-spawning mortality occurred.

Despite an apparent lack of mortality during periods of stressful feeding conditions, consumption seemed to affect changes in brook trout populations at the 
watershed scale. Mean consumption was positively correlated with total population change, but not population change of larger individuals. Changes in population estimates could have occurred via movement or mortality. The lack of a relationship between consumption and large fish population changes could have been attributed to movement of larger fish. In central Appalachia, adult brook trout are capable of moving large distances (Logan 2003, Thorne 2004, Petty et al. 2005) and may move in order to improve spawning or foraging conditions (Lamothe 2002). Therefore, the lack of a relationship between adult populations and consumption may be caused by an inability to accurately assess $110 \mathrm{~mm}+$ fish populations due to movement. The relationship between total fish population and mean consumption implies that temporal feeding conditions are similar between fish sampled for gut contents and fish considered too small for gastric lavage. Though larger fish tend to defend more productive territories and exclude smaller individuals (Persson 1985, Grant and Kramer 1990, Nakano 1995), resource availability is linked to seasonal change. Therefore, though smaller individuals may inhabit territories of poor quality, temporal variations in resource availability likely affect all fish. Thus correlations between total population change and observed consumption of one size class of fish should be expected.

Growth rates varied predictably with temporal change and followed trends similar to changes in consumption, though variables other than consumption were likely influential. Only two significantly different periods of growth were recorded; those ending in the spring (positive growth) and those ending in all other months. Though fish size may significantly affect growth rates of salmonids (Elliot 1976, McKinney and Speas 2001), trends in size-corrected growth differed only slightly from patterns in 
overall growth. Temperature may also play an important role in growth rates of lotic salmonids (Jensen 1990). Although this study was not designed to examine the effects of temperature on brook trout growth, the effects of temperature were indirectly considered when calculating gastric evacuation and maintenance metabolism. Thus comparisons between growth and consumption contain temperature variables. Factors other than those mentioned likely affected growth rates as well, such as gamete hydrolysis during the fall (Power 1980); this process probably influenced the growth rate between August 2004 and September 2004 in this study (fish were gravid during the September sampling).

Nevertheless, growth rates were significantly correlated with consumption, and variations in growth rates were highly influenced by temporal change.

The sometimes erratic change in growth rates during the course of the study may have important implications. The change in growth rates between late spring and early summer was particularly dramatic, shifting from positive and high between May and June to negative between June and July during both years. The importance of sampling frequency when studying growth rates is highlighted. For instance, if the June 2004 sample is omitted, growth rates between May 2004 and July 2004 would have been calculated as $0.294 \% \mathrm{~d}^{-1}$. From this observation, one may conclude that summer offers favorable conditions for growth up until mid July. However, data in the current study shows that growth during the mid to late summer is consistently poor. Other studies have examined brook trout growth rates using longer intervals of time (Cada et al. 1987, Lamothe 2003, Thorne 2004) with various results. Specifically, Cada et al. (1987) reported that the highest growth rates in adult southern Appalachian salmonids occurred over the winter, while Thorne (2004) and Lamothe (2002) reported positive mean growth 
rates over summer. Growth rates in the current study did not concur with either of these findings; however, the intervals between sampling events were shorter in the current study. Therefore, conclusions previously made about Appalachian salmonid growth rates could have been distorted due to the growth fluctuations that may occur seasonally. However, despite the detailed report of temporal growth rates, intensive shocking regimens may pose problems in assessing growth.

Electrofishing has been shown to significantly decrease growth rates in salmonids (Gatz et al. 1986, Dwyer and White 1995, Dwyer and White 1997 Hughes 1998), and the frequency of electrofishing in the current study may have affected growth rates.

Reductions in growth rates may be caused by internal injury, which has been documented in wild brook trout populations in streams similar to those in the current study (Hollender and Carline 1994). Nevertheless, the growth rates recorded during intervals in 2005, after a year of study, were not significantly different from the same intervals recorded in 2004 when the brook trout population had been exposed to fewer electrofishing events. Further, growth rates were significantly correlated with corresponding consumption estimates (though consumption estimates were not derived from tagged fish only). Injury as a result of electrofishing is more common in larger fish (Hollender and Carline 1994), and the fish observed in this study were much smaller than fish used in the laboratory experiments examining the effects of electrofishing mentioned above. Larger fish that are more susceptible to injury typically grow less under normal conditions (Whitworth and Strange 1983, Cada et al. 1987). Therefore, while growth values may be underestimated, overall trends in growth in the observed brook trout population are likely accurate. Minimal effects of electrofishing at the population level aside from growth (i.e. 
mortality and movement) have been observed (Habera et al. 1996, Carline 2001, Dunham et al. 2002), suggesting that while individuals may be damaged by electrofishing induced injury, population level processes may be affected little by electrofishing. Those studies which have reported Appalachian salmonid growth rates contrasting those found in the current study (Cada et al. 1987, Lamothe 2002, Thorne 2004) sampled fish multiple times over the course of a year using DC pulsed electrofishing. Therefore, injuries sustained by fish in the current study would have been similar in fish sampled in other mentioned studies, likely rendering growth rates comparable between the current study and others.

\section{Fish Density and Consumption}

Across all seasons, trout density was negatively correlated with stream size for all fish and fish eligible for gastric lavage. Similar trends have been observed in nearby watersheds (Petty et al. 2005) and likely has to do with life history strategy. Brook trout utilize different locations in the watershed for foraging, feeding or refugia; upstream reaches of streams are most often used for spawning (Power 1980, Curry et al 2002). The exploitation of foraging habitat (downstream) may require long-distance movement from natal stream areas and such movements may be energetically costly (Schlosser 1991, 1995). As a result, stream fish densities may be directly related to size-specific habitat requirements, as seen in this study. However, the trends in fish density at the watershed scale did not result in fish distribution patterns based on resource availability.

Mean consumption seemed to be influenced by watershed position and trout density throughout the year. Specifically, during both spring and summer, fish in downstream and midstream reaches derived a significantly higher amount of energy from their environments than fish occupying upstream reaches. This finding concurs with 
others that have found movement in a downstream direction improves foraging conditions (Schlosser 1991, 1995). The trend reversed during winter, with significantly higher energy intake occurring in upstream reaches; however, this period of time is associated with low growth due to low temperatures as seen in this study. Therefore the most consequential seasons concerning consumption rates occur during warmer months. Consumption was negatively correlated with large fish density during the summer and fall months.

One mechanism allowing increased feeding in downstream reaches may be territoriality. Stream-dwelling salmonids defend territories from invaders and benefit from increased foraging and growth rates in higher quality territories (Hughes 1992, Nakano 1995). In downstream reaches, an increased amount of space and decreased number of fish could ease territory defense and size, potentially resulting in increased growth through increased foraging rates or lower metabolic costs. Larger fish have been found to defend high-quality territories (Grant and Kramer 1990, Nakano 1995), and fish in downstream reaches were more capable of exploiting particularly important prey taxa (Chapter 3) during the corresponding seasons, such as Coleoptera during the spring and Lepidoptera during summer. Additionally, the occupation of downstream territories may increase growth rates. Salmonids physically defend territories from other fish, and such acts require the expenditure of energy that could otherwise be used for growth or metabolism (Metcalfe 1986). Growth rates were not comparable between sites in this study due to low recapture rates in some reaches. However, the trends observed in consumption may suggest that fish in down and midstream reaches may have spent less time defending territory and more time foraging, potentially resulting in a greater 
capacity for growth than fish upstream. Thorne (2004) found increased growth rates in larger order systems, as the spatial scale used was similar the finding concurs with the current study. This disproportionate rate of resource exploitation may have implications for brook trout distributional ecology.

Organisms tend to distribute via one of two mechanisms: ideal-free distribution, which states that organisms distribute based on resource availability, or competitive dominant, where organisms distribute by competitive interactions (Fretwell and Lucas 1970). In the current study, brook trout that moved away from natal upstream reaches were rewarded with an increased rate of energy intake. This observation points to competitive-dominant distribution in brook trout, as fish choosing to move downstream assumed a competitive advantage over those that stayed in upstream reaches. As a result, fish were apparently disproportionately distributed according to resources at the watershed scale due to the competitive nature of migrating individuals. Other studies, however, have observed ideal-free mechanisms in stream salmonids, both at the local (Kawaguchi et al 2003) and watershed (Bohlin et al 1994, Hughes and Reynolds 1994) scale. Factors other than food resources, such as territoriality, may be driving ideal-free distribution in salmonids.

Salmonids defend contiguous territories, and the defense of such territories coupled with food availability may affect the abundance of stream salmonids. Studies of salmonid territoriality show that territory size is related to fish size, but not food availability except when food resources are abnormally high (Keeley 2000, Imre et al. 2004). Therefore, when food resources limit growth (as is often the case), lotic salmonid populations will be subject to emigration as subordinate individuals are forced to cope 
with the exclusion of resources (Grant et al. 1998, Imre et al. 2004). As a result, lotic salmonids become dispersed throughout the watershed as territories and food resources become evenly distributed among fish throughout the watershed. The current study did not directly quantify brook trout territory or total food abundance. Regardless, food abundance has been shown to explain approximately $84 \%$ of the variation in salmonid abundance (Imre et al. 2004). The significant differences in energy acquisition observed in the current study between reaches suggest that the Middle Fork River brook trout population most likely did not redistribute on a territory and resource scale.

If brook trout truly operate under ideal-free distribution, it is unclear why consumption rates were not proportionally distributed with density in this study. The high density of fish in small, upper reaches of streams was likely related to reproductive success at these sites, yet some movement from these sites by adult fish should be expected (Petty et al. 2005). One causal mechanism may be fishing pressure, which tends to remove larger individuals (Marscall and Crowder 1996) and may be influential in structuring populations in the system studied (Webster 2004). Though all sites included in the current study are on private land and road access is limited due to locked gates on logging roads, most downstream and some midstream sections in this study are close (approximately $<1 \mathrm{~km}$ or less) to public roadways, and may be affected by angling pressure. If angling mortality was the cause of reduced populations in downstream and midstream sections, population decline would be expected in these reaches during seasons of high angling activity, such as spring and summer. Yet large fish populations remained relatively stable during these seasons. Therefore, it remains unclear if angling mortality reduced the ability of Middle Fork River brook trout to exploit downstream 
resources. Multiple studies (Logan 2003, Petty et al. 2005) show that brook trout are highly capable of long distance movements in the Middle Fork watershed, and the current study illustrates that downstream reaches offer favorable foraging conditions. Future research examining the cause of low population density in downstream reaches could help define what management decisions could be made in order to improve brook trout populations in central Appalachian watersheds.

\section{Management Implications}

Findings in this study highlight important temporal and qualitative details of brook trout feeding ecology over the course of the year. This study and others (Cada et al 1987, Ensign et al 1990, Sweka 2003, Thorne 2004) note the importance of mid-summer as a stressful period of energy intake for brook trout. Brook trout may rely on a generalist feeding pattern and occasional successful feeding periods to survive typical summer seasons. Further, this study underscores the importance of carefully considering temporal change when examining growth. Growth rates changed significantly over a short period of time, and positive growth was only realized during the spring and early summer.

Location appears to be an important factor in determining the level of energy intake in a brook trout population. While attention must be paid to upstream reaches of streams and brook trout spawning success to ensure population persistence (Petty et al. 2005), foraging habitat may play a disproportionately important role in providing areas to promote fish growth. The population in this study did not appear to be distributed evenly in relation to resources. If improvements are made which enhance the suitability of downstream reaches to brook trout, such as the removal of barriers or reductions in 
angling mortality, headwater brook trout populations may improve in quantity and fish size. 


\section{References}

Benke, A. C., Huryn, A. D., Smock, L. A., and Wallace, J. B. 1999. Length-mass relationships for freshwater macroinvertebrates in North America with particular reference to the southeastern United States. Journal of the North American Benthological Society 18: 308-343.

Borror, D. J., Triplehorn, C. A., and Johnson, N. F. 1989. An introduction to the study of insects, $6^{\text {th }}$ ed. Saunders College Publishers, Ft. Worth, Texas.

Bohlin, T., Dellefores, C., Faremo, U., and Johlander, A. 1994. The energetic equivalence hypothesis and the relation between population density and body size in stream-living salmonids. The American Naturalist 143: 478-493.

Bowen, Stephen H. 1996. Quantitative description of the diet. Edited by B. R. Murphy and D. W. Willis. Fisheries Techniques, $2^{\text {nd }}$ edition. American Fisheries Society, Bethesda, MD. pp. 513-529

Cada, G. F., Loar, J. M., and Sale, M. J. 1987. Evidence of food limitation of rainbow and brown trout in southern Appalachian soft-water streams. Transactions of the American Fisheries Society 116: 692-702.

Carline, R. F. 2001. Effects of high-frequency pulsed-DC electrofishing on a wild brown trout population. North American Journal of Fisheries Management 21: 571-579.

Carline, R. F. and McCullough, B. J. 2003. Effects of floods on brook trout populations in the Monongahela National Forest, West Virginia. Transactions of the American Fisheries Society 132: 1014-1020.

Clark, M. E. and Rose, K. A. 1997. Factors affecting competitive dominance of rainbow trout over brook trout in southern Appalachian streams: implications of an individualbased model. Transactions of the American Fisheries Society 126: 1-20.

Clayton, J. L., Dannaway, E. S., Menendez, R., Rauch, H. W., Renton, J. J., Sherlock, S. M., and Zurbuch, P. E. 1998. Application of limestone to restore fish communities in acidified streams. American Journal of Fisheries Management 18: 347-360.

Cummins, K. C. and Wuycheck, J. C. 1971. Caloric equivalents for investigations in ecological energetics. Mitteilungen der Internationalen Vereinigung fur Theoretische und Angewandte Limnologie 18.

Cunjak, R. A. 1988. Physiological consequences of overwintering in streams: the cost of acclimization? Canadian Journal of Fisheries and Aquatic Science 45: 443-452.

Cunjak, R. A. and Power, G. 1987. The feeding and energetics of stream-resident trout in winter. Journal of Fish Biology 31: 493-511. 
Curry, R. A., Sparks, D., and van de Sande, J. 2002. Spatial and temporal movements of a riverine brook trout population. Transactions of the American Fisheries Society 131: 551-560.

De Crespin de Billy, V., Dumont, B., Lagarrigue, T., Baran, P., and Statzner, B. 2002. Invertebrate accessibility and vulnerability in the analysis of brown trout (Salmo trutta L.) summer habitat suitability. River Research and Applications 18: 533-553.

Dolloff, C. A., Jennings, H. E., and Owen, M. D. 1997. A comparison of basinwide and representative reach habitat survey techniques in three southern Appalachian watersheds. North American Journal of Fisheries Management 17: 339-347.

Dunham, K. A., Stone, J., and Moring, J. R. 2002. Does electrofishing influence movements of fishes in streams? Experiments with brook trout (Salvelinus fontinalis). Fisheries Management and Ecology 9: 249-251.

Dwyer, W. P. and White, R. G. 1995. Influence of electroshock on short-term growth of adult rainbow trout and juvenile Arctic grayling and cutthroat trout. North American Journal of Fisheries Management 15: 148-151.

Dwyer, W. P. and White, R. G. 1997. Effect of electroshock on juvenile Arctic grayling and Yellowstone cutthroat trout growth, 100 days after treatment. North American Journal of Fisheries Management 17: 174-177.

Eggers, D. M. 1977. Factors in interpreting data obtained by diel sampling of fish stomachs. Journal of the Fisheries Research Board of Canada 34: 290-294.

Elliot, J. M. 1976. The energetics of feeding, metabolism, and growth of brown trout (Salmo trutta L.) in relation to body weight, water temperature, and ration size. Journal of Animal Ecology 45:923-948.

Ensign, W. E., Strange, R. J., and Moore, S. E. 1990. Summer food limitation reduces brook and rainbow trout biomass in a southern Appalachian stream. Transactions of the American Fisheries Society 119: 894-901.

Filbert, R. B. and Hawkins, C. P. 1995. Variation in condition of rainbow trout in relation to food, temperature and individual length in the Green River, Utah. Transactions of the American Fisheries Society 124: 824-835.

Forrester, G. E., Chace, J. G., and McCarthy, W. 1994. Diel and density-related changes in food consumption and prey selection by brook charr in a New Hampshire stream. Environmental Biology of Fishes 39: 301-311.

Fretwell, S. D., and Lucas, H. D. 1970. On the territorial behavior and other factors influencing habitat distribution in birds. I. Acta Biotheoretica 19: 16-36. 
Grant, J. W. A. and Kramer, D. L. 1990. Territory size as a predictor of the upper limit to population density of juvenile salmonids in streams. Canadian Journal of Fisheries and Aquatic Sciences 47: 1724-1737.

Grant, J. W. A., Steingrimsson, S. O., Keeley, E. R., and Cunjak, R. A. 1998. Implications of territory size for the measurement and prediction of salmonid abundance in streams. Canadian Journal of Fisheries and Aquatic Science 55 (Suppl. 1): 181-190.

Habera, J. A., Strange, R. J., Carter, B. D., and Moore, S. E. 1996. Short-term mortality and injury of rainbow trout caused by three-pass AC electrofishing in a southern Appalachain stream. North American Journal of Fisheries Management 16: 192-200.

Hakala, J. P. and Hartman, K. J. 2004. Drought effect on stream morphology and brook trout (Salvelinus fontinalis) populations in forested headwater streams. Hydrobiologia 515: 203-213.

Hartman, K. J. and Brandt, S. B. 1995. Estimating energy density of fish. Transactions of the American Fisheries Society 124: 347-355.

Hartman, K. J. and Sweka, J. A. 2001. Development of a bioenergetics model for Appalachian brook trout. Procedures from the Annual Conference of Southeastern Assosiation of Fisheries and Wildlife Agencies 55: 38-51.

Hollender, B. A. and Carline, R. F. 1994. Injury to wild brook trout by backpack electrofishing. North American Journal of Fisheries Management 14: 643-649.

Hughes, N. F. 1992. Ranking of feeding positions by drift-feeding Arctic grayling (Thymallus arcticus) in dominance hierarchies. Canadian Journal of Fisheries and Aquatic Science 49: 1994-1998.

Hughes, N. F. 1998. Reduction in growth due to electrofishing and tagging may change interannual movement behavior of stream salmonids: evidence from Arctic Grayling in an interior Alaskan stream. Transactions of the American Fisheries Society 127: 10721077.

Hughes, N. F. 1999. Population processes responsible for larger-fish-upstream distribution patterns of Arctic grayling (Thymallus arcticus) in interior Alaskan runoff rivers. Canadian Journal of Fisheries and Aquatic Science 56: 2292-2299.

Hughes, N. F. 2000. Testing the ability of habitat selection theory to predict interannual movement patterns of a drift-feeding salmonid. Ecology of Freshwater Fish 9: 4-8.

Hughes, N. F. and Reynolds, J. B. 1994. Why do Arctic grayling (Thymallus arcticus) get bigger as you go upstream? Canadian Journal of Fisheries and Aquatic Science 51: 2154-2163. 
Imre, I., Grant, W. A., and Keeley, E. R. 2004. The effect of food abundance on territory size and population density of juvenile steelhead trout (Oncorhynchus mykiss). Oecologia 138: 371-378.

Jensen, A. J. 1990. Growth of young migratory brown trout Salmo trutta correlated with water temperature in Norwegian rivers. Journal of Animal Ecology 59: 603-614.

Johnston, T. A. and Cunjak, R. A. 1999. Dry mass-length relationships for benthic insects: a review with new data from Catamaran Brook, New Brunswick, Canada. Freshwater Biology 41: 653-674.

Kawaguchi, C., Taniguchi, Y., and Nakano, S. 2003. Terrestrial invertebrate inputs determine the local abundance of stream fishes in a forested stream. Ecology 84: 701708 .

Kawaguchi, Y. and Nakano, S. 2001. Contribution of terrestrial invertebrates to the annual resource budget for salmonids in forest and grassland reaches of a headwater stream. Freshwater Biology 46: 303-316.

Keeley, E. R. 2000. An experimental analysis of territory size in juvenile steelhead trout. Animal Behaviour 59: 477-490.

Lamothe, P. J. 2002. Spatial population dynamics of brook trout (Salvelinus fontinalis) in a central Apppalachian watershed. M.Sc. thesis, Division of Forestry, West Virginia University, Morgantown, WV.

Light, R. W., Adler, P. H., and Arnold, D. 1983. Evaluation of gastric lavage for stomach analyses. North American Journal of Fisheries Management 3: 81-85.

Logan, M. N. 2003. Brook trout (Salvelinus fontinalis) movement and habitat use in a headwater stream of the central Appalachian mountains of West Virginia. M.Sc. thesis, Division of Forestry, West Virginia University, Morgantown, WV.

Marscall, E. A. and Crowder, L. B. 1996. Assessing population responses to multiple anthropogenic effects: a case study with brook trout. Ecological Applications 6: 152-167.

McClurg, S. E. 2004. Stream ecosystem response to mitigative limestone treatment in acid impaired, Central Appalachian streams. M.Sc. thesis, Division of Forestry, West Virginia University, Morgantown, WV.

McKinney, T. and Speas, D. W. 2001. Observations of a size-related asymmetries in diet and energy intake of rainbow trout in a regulated river. Environmental Biology of Fishes 61: $435-444$.

Merritt, R. W. and Cummins, K. W. 1996. An introduction to the aquatic insects of North America, $3^{\text {rd }}$ edition. Kendall and Hunt, Dubuque, IA. 
Metcalfe, N. B. 1986. Intraspecific variation in competitive ability and food intake in salmonids: consequences for energy budgets and growth rates. Journal of Fish Biology 28: $525-531$.

Mood, A. M., Graybill, F. A., and Boes, D. C. 1974. Introduction to the theory of statistics, $3^{\text {rd }}$ edition. McGraw-Hill, New York.

Mookerji, N. , Weng, Z., and Mazumder, A. 2004. Food partitioning between coexisting Atlantic salmon and brook trout in the Sainte-Marguerite River ecosystem, Quebec. Journal of Fish Biology 64: 680-694.

Nakano, S. 1995. Individual differences in resource use, growth, and emigration under the influence of a dominance hierarchy in flucial red-spotted masu salmon in a natural habitat. Journal of Animal Ecology 64: 75-84.

Nakano, S., Miyasaka, H., and Kuhara, N. 1999. Terrestrial-aquatic linkages: riparian arthropod inputs alter trophic cascades in a stream food web. Ecology 80: 2435-2441.

Neveu, A. 1999. Feeding strategy of the brown trout (Salmo trutta L.) in running water. Edited by J. L. Bagliniere and G. Maisse. Biology and Ecology of the Brown and Sea Trout. Springer, Chichester, UK. pp 91-113.

Persson, L. 1985. Asymmetrical competition: Are larger animals competitively superior? The American Naturalist 126: 261-266.

Petty, J. T., Lamothe, P. J., and Mazik, P. M. 2005. Spatial and seasonal dynamics of brook trout populations inhabiting a central Appalachian watershed. Transactions of the American Fisheries Society 134: 572-587.

Platts, W. S. and Nelson, R. L. 1988. Fluctuations in trout populations and their implications for land-use evaluation. North American Journal of Fisheries Management 8: $333-345$.

Power, G. 1980. The brook charr, Salvelinus fontinalis. Edited by E. K. Balon. Charrs: Salmonid Fishes of the genus Salvelinus. Dr. W. Junk bv Publishers, The Hague, Denmark. pp 141-202.

Sabo, J. L., Bastow, J. L., and Power, M. E. 2002. Length-mass relationships for adult aquatic and terrestrial invertebrates in a California watershed. Journal of the North American Benthological Society 21: 336-343.

Sample, B. E., Cooper, R. J., Greer, R. D., and Whitmore, R. C. 1993. Estimation of insect bimass by length and weight. American Midland Naturalist 129: 234-240.

Schlosser, I. J. 1995. Critical landscape attributes that influence fish population dymanics in headwater streams. Hydrobiologia 303: 71-81. 
Schlosser, I. J. 1991. Stream fish ecology: a landscape perspective. BioScience 41: 704712.

Steinhart, G. B. and Wurtsbaugh, W. A. 2003. Winter ecology of Kokanee: implications for salmon management. Transactions of the American Fisheries Society 132: 1076-1088.

Sweka, J. A. 2003. Aquatic-terrestrial linkages in Appalachian streams: influence of riparian inputs on stream habitat, brook trout populations, and trophic dynamics. Ph.D. dissertation, Division of Forestry, West Virginia University, Morgantown, WV.

Sweka, J. A. , Cox, M. K., and and Hartman, K. J. 2004. Gastric evacuation rates of brook trout. Transactions of the American Fisheries Society 133: 204-210.

Thorne, D. W. 2004. Spatial and seasonal variation in brook trout diet, growth, and consumption in a complex Appalachian watershed . M.Sc. thesis, Division of Forestry, West Virginia University, Morgantown, WV.

Twomey, H. and Giller, P. S. 1990. Stomach flushing and individual Panjet tattooing of salmonids: an evaluation of the long-term effects on two wild populations. Aquaculture and Fisheries Management 21: 137-142.

Vannote, R. L., Minshall, G. W., Cummins, K. W., Sedell, J. R., and Cushing, C. E. 1980. The river continuum concept. Canadian Journal of Fisheries and Aquatic Science 37: 130-137.

Webster, J. 2004. Reasons for overwinter declines in age-1+ brook trout populations (Salvelinus fontinalis) in Appalachian headwater streams. M.Sc. thesis, Division of Forestry, West Virginia University, Morgantown, WV.

White, G. C., Anderson, D. R., Burnham, K. P., and Otis, D. L. 1982. Capture-recapture and removal methods for sampling closed populations. Los Alamos National Laboratory LA-8787-NERP, Los Alamos, New Mexico.

Whitworth, W. E. and Strange, R. J. 1983. Growth and production of sympatric brook and rainbow trout in an Appalachian stream. Transactions of the American Fisheries Society 112: 469-475.

WVDNR (West Virginia Division of Natural Resources). 2001. Middle Fork River: Limestone treatment of acid mine drainage. Elkins, West Virginia. 


\section{Tables}

Table 1. Physical features and number of fish species encountered for each site in the Middle Fork River watershed. The column titled 'Limed' refers to whether or not an active limestone treatment site existed above the site reach. If the site was not limed, water quality in the study reach retained the ability to hold young-of-the-year brook trout.

\begin{tabular}{|c|c|c|c|c|c|c|c|c|c|}
\hline Site Name & Stream & $\begin{array}{l}\text { Limed } \\
(\mathrm{Y} / \mathrm{N})\end{array}$ & $\begin{array}{c}\text { Stream } \\
\text { Class }\end{array}$ & $\begin{array}{l}\text { Basin } \\
\text { Area } \\
\left(\mathrm{km}^{2}\right)\end{array}$ & $\begin{array}{c}\text { Mean } \\
\text { Wetted } \\
\text { Width (m) }\end{array}$ & $\begin{array}{c}\text { Mean } \\
\text { Bankful } \\
\text { Width (m) }\end{array}$ & Mean pH & $\begin{array}{c}\text { Mean } \\
\text { Alkalinity } \\
(\mathrm{mg} / \mathrm{l})\end{array}$ & $\begin{array}{c}\text { Observed } \\
\text { Fish } \\
\text { Species }\end{array}$ \\
\hline Brush & Brush Run & $\mathrm{N}$ & Upstream & 0.83 & 1.46 & 3.97 & 5.17 & 1.38 & 1 \\
\hline KittleLOW & Kittle Creek & $\mathrm{Y}$ & Downstream & 15.38 & 4.77 & 9.36 & 6.27 & 6.30 & 8 \\
\hline KittleMID & Kittle Creek & $\mathrm{Y}$ & Midstream & 5.26 & 2.44 & 5.89 & 6.30 & 5.33 & 4 \\
\hline KittleUP & Kittle Creek & $\mathrm{Y}$ & Upstream & 2.05 & 2.19 & 3.98 & 6.73 & 15.78 & 2 \\
\hline Light & Light Run & $\mathrm{N}$ & Midstream & 5.24 & 3.13 & 7.07 & 6.04 & 3.60 & 4 \\
\hline Mitchell & Mitchell Lick Fork & $\mathrm{Y}$ & Upstream & 1.78 & 2.08 & 5.02 & 6.25 & 6.25 & 1 \\
\hline RockyLOW & Rocky Run & $\mathrm{Y}$ & Downstream & 9.94 & 4.36 & 7.98 & 5.51 & 2.08 & 7 \\
\hline RockyUP & Rocky Run & $\mathrm{Y}$ & Midstream & 6.44 & 3.76 & 9.14 & 5.42 & 1.68 & 1 \\
\hline Sugar & Sugar Drain & $\mathrm{N}$ & Upstream & 1.64 & 2.42 & 5.36 & 6.47 & 8.05 & 2 \\
\hline
\end{tabular}


Table 2. Dates of fish sampling in the Middle Fork River designated by month.

\begin{tabular}{ccc}
\hline Sampling Period & Start date & End date \\
\hline March 2004 & $3 / 13$ & $3 / 20$ \\
May 2004 & $5 / 10$ & $5 / 12$ \\
June 2004 & $6 / 13$ & $6 / 16$ \\
July 2004 & $7 / 16$ & $7 / 19$ \\
August 2004 & $8 / 16$ & $8 / 18$ \\
September 2004 & $9 / 24$ & $9 / 26$ \\
December 2004 & $12 / 2$ & $12 / 5$ \\
March 2005 & $3 / 12$ & $3 / 18$ \\
May 2005 & $5 / 9$ & $5 / 11$ \\
June 2005 & $6 / 9$ & $6 / 11$ \\
July 2005 & $7 / 12$ & $7 / 13$ \\
\hline
\end{tabular}


Table 3. Energy densities by wet weight (WW) of brook trout removed from random sites during selected sampling periods. A subset of brook trout were removed in order to estimate energy density, a component of bioenergetics models.

\begin{tabular}{ccc}
\hline Month & $\begin{array}{c}\text { Energy Density } \\
\left(\mathrm{J} \mathrm{g}^{-1} \mathrm{WW}\right)\end{array}$ & $\mathrm{SE}$ \\
\hline September04 & 4042 & 220 \\
December04 & 4784 & 174 \\
March05 & 4631 & 181 \\
May05 & 3429 & 193 \\
July05 & 4461 & 242 \\
\hline
\end{tabular}


Table 4. Energy densities by dry weight (DW) of prey types encountered in brook trout stomachs (from Cummins and Wuycheck 1971).

\begin{tabular}{|c|c|c|}
\hline Order & Stage & $\begin{array}{c}\text { Energy Density } \\
\left(\mathrm{J} \mathrm{g}^{-1} \mathrm{DW}\right)\end{array}$ \\
\hline Acarina & Adult & 24318.1 \\
\hline Anura & Adult & 6858.3 \\
\hline Aranae & Adult & 20202.3 \\
\hline Blatteria & Adult & 22835.9 \\
\hline Caudata & Adult & 6858.3 \\
\hline Coleoptera & Adult & 23263.0 \\
\hline Coleoptera & Larval & 25721.2 \\
\hline Collembola & Adult & 23263.0 \\
\hline Cypriniformes & Adult & 30502.3 \\
\hline Decapoda & Adult & 22249.7 \\
\hline Diplopoda & Adult & 22145.0 \\
\hline Diptera & Adult & 24213.4 \\
\hline Diptera & Larval & 24818.3 \\
\hline Diptera & Pupa & 24818.3 \\
\hline Ephemeroptera & Adult & 22898.7 \\
\hline Ephemeroptera & Larval & 22898.7 \\
\hline Gastropoda & Adult & 8474.5 \\
\hline Hemiptera & Adult & 23606.3 \\
\hline Homoptera & Adult & 23606.3 \\
\hline Hymenoptera & Adult & 19381.6 \\
\hline Hymenoptera & Larval & 19381.6 \\
\hline Isopoda & Adult & 18586.1 \\
\hline Lepidoptera & Adult & 22835.9 \\
\hline Lepidoptera & Larval & 22835.9 \\
\hline Mecoptera & Adult & 22195.6 \\
\hline Megaloptera & Adult & 22835.9 \\
\hline Megaloptera & Larval & 22835.9 \\
\hline Neuroptera & Adult & 22835.9 \\
\hline Odonata & Adult & 21424.9 \\
\hline Odonata & Larval & 21424.9 \\
\hline Oligochaetae & Adult & 23342.5 \\
\hline Opililiones & Adult & 22145.0 \\
\hline Orthoptera & Adult & 22835.9 \\
\hline Plecoptera & Adult & 20193.9 \\
\hline Plecoptera & Larval & 22717.8 \\
\hline Psocoptera & Adult & 22835.9 \\
\hline Salmiformes & Adult & 19343.9 \\
\hline Scorpioniformes & Adult & 16547.0 \\
\hline Thysanoptera & Adult & 22835.9 \\
\hline Trichoptera & Adult & 20930.8 \\
\hline Trichoptera & Larval & 21040.0 \\
\hline Zoraptera & Adult & 22835.9 \\
\hline
\end{tabular}


Table 5. Designations of sampling periods into season for analyses of consumption estimates. Classifications were based on feeding intensity and temperature. Means within a column with different letters are significantly different following a square root transformation in order to approximate normality. Consumption estimates are in joules per gram wet weight of fish per day.

\begin{tabular}{lccc}
\hline Season & $\begin{array}{c}\text { Sampling } \\
\text { Periods }\end{array}$ & $\begin{array}{c}\text { Mean } \\
\text { Temperature }\left({ }^{\circ} \mathrm{C}\right)\end{array}$ & $\begin{array}{c}\text { Mean } \\
\text { Consumption } \\
\left(\mathrm{J} \mathrm{g}^{-1} \mathrm{~d}^{-1}\right)\end{array}$ \\
\hline Spring & May 2004 & 11.04 & $57.19^{\mathrm{A}}$ \\
& June 2004 & 15.88 & $49.73^{\mathrm{A}}$ \\
& May 2005 & 12.49 & $59.79^{\mathrm{B}}$ \\
& June 2005 & 15.40 & $38.66^{\mathrm{C}}$ \\
Summer/Fall & & & \\
& July 2004 & 16.20 & $16.91^{\mathrm{D}, \mathrm{E}}$ \\
& August 2004 & 18.02 & $18.62^{\mathrm{E}, \mathrm{F}}$ \\
& September 2004 & 14.37 & $20.99^{\mathrm{D}}$ \\
& July 2005 & 16.87 & $22.95^{\mathrm{D}}$ \\
& & & \\
& March 2004 & 5.33 & $6.99^{\mathrm{F}}$ \\
& December 2004 & 5.19 & $11.51^{\mathrm{E}, \mathrm{F}}$ \\
& March 2005 & 2.61 & $7.92^{\mathrm{F}}$ \\
\hline
\end{tabular}


Table 6. Mean estimated consumption and maintenance ration (EMR) per month. T-test results of differences between square-root transformed EMR and consumption for each month are provided. The number of fish encountered with no food items present in the gut per month is provided (\# empty).

\begin{tabular}{|c|c|c|c|c|c|c|c|c|c|}
\hline \multirow[b]{2}{*}{ Month } & \multirow[b]{2}{*}{$\mathrm{n}$} & \multirow{2}{*}{$\begin{array}{c}\# \\
\text { Empty }\end{array}$} & \multicolumn{2}{|c|}{ EMR } & \multicolumn{2}{|c|}{ Consumption } & \multirow[b]{2}{*}{$\mathrm{t}$} & \multirow[b]{2}{*}{$\mathrm{df}$} & \multirow[b]{2}{*}{$P$} \\
\hline & & & Mean & SE & Mean & SE & & & \\
\hline March04 & 76 & 2 & 12.03 & 0.14 & 6.99 & 0.84 & -5.80 & 75 & $<0.0001$ \\
\hline May04 & 87 & 0 & 10.75 & 0.16 & 57.19 & 8.08 & 5.74 & 86 & $<0.0001$ \\
\hline June04 & 85 & 1 & 12.97 & 0.17 & 49.73 & 4.71 & 7.79 & 84 & $<0.0001$ \\
\hline July04 & 88 & 7 & 18.32 & 0.65 & 16.91 & 2.59 & -0.54 & 87 & 0.5910 \\
\hline August04 & 83 & 10 & 18.59 & 0.28 & 18.62 & 4.25 & $<0.01$ & 82 & 0.9960 \\
\hline September04 & 84 & 3 & 15.09 & 0.45 & 20.99 & 2.69 & 2.19 & 83 & 0.0314 \\
\hline December04 & 77 & 4 & 11.59 & 0.14 & 11.51 & 1.19 & -0.06 & 76 & 0.9499 \\
\hline March05 & 89 & 3 & 10.34 & 0.15 & 7.92 & 1.11 & -2.21 & 88 & 0.0294 \\
\hline May05 & 90 & 0 & 11.86 & 0.18 & 59.79 & 4.11 & 11.60 & 89 & $<0.0001$ \\
\hline June05 & 90 & 0 & 13.34 & 0.17 & 38.66 & 3.95 & 6.40 & 89 & $<0.0001$ \\
\hline July05 & 90 & 4 & 19.22 & 0.28 & 22.95 & 4.03 & 0.93 & 89 & 0.3526 \\
\hline
\end{tabular}


Table 7. Mean growth (G) and size-adjusted growth (Gi) across all elapsed time periods eligible for growth analysis. Means within each column with different letters are significantly different from each other.

\begin{tabular}{lccc}
\hline Period of Elapsed Time & $\mathrm{n}$ & $\mathrm{G}\left(\% \mathrm{~d}^{-1}\right)$ & $\mathrm{Gi}\left(\% \mathrm{~d}^{-1}\right)$ \\
\hline May04 to June04 & 77 & $0.419^{\mathrm{A}}$ & $0.1289^{\mathrm{A}}$ \\
June04 to July04 & 41 & $-0.125^{\mathrm{B}, \mathrm{C}}$ & $-0.0318^{\mathrm{B}}$ \\
July04 to August04 & 26 & $-0.036^{\mathrm{B}, \mathrm{C}}$ & $-0.0129^{\mathrm{B}}$ \\
August04 to September04 & 23 & $0.003^{\mathrm{B}, \mathrm{C}}$ & $0.0003^{\mathrm{B}}$ \\
September04 to December04 & 23 & $-0.190^{\mathrm{C}}$ & $-0.0524^{\mathrm{B}}$ \\
December04 to March05 & 84 & $0.022^{\mathrm{B}}$ & $0.0116^{\mathrm{B}}$ \\
March05 to May05 & 88 & $0.382^{\mathrm{A}}$ & $0.1502^{\mathrm{A}}$ \\
May05 to June05 & 110 & $0.330^{\mathrm{A}}$ & $0.1244^{\mathrm{A}}$ \\
June05 to July05 & 122 & $-0.136^{\mathrm{B}, \mathrm{C}}$ & $-0.0420^{\mathrm{B}}$ \\
\hline
\end{tabular}


Table 8. Population estimates \pm standard error (SE) of all fish and fish large enough to sample gut contents $(110+\mathrm{mm}$ FL). Estimates for each $200 \mathrm{~m}$ stream section are combined across all sites per month.

\begin{tabular}{ccrrcc}
\hline & \multicolumn{2}{c}{ All Fish } & & \multicolumn{2}{c}{$110+\mathrm{mm} \mathrm{FL}$} \\
\cline { 2 - 3 } \cline { 5 - 6 } Month & Population & \multicolumn{1}{c}{ SE } & & Population & SE \\
\hline August04 & 526 & 26.36 & & 177 & 0.25 \\
December04 & 345 & 6.56 & & 133 & 0.00 \\
July04 & 541 & 6.64 & & 199 & 0.15 \\
July05 & 549 & 6.32 & & 234 & 4.29 \\
June04 & 522 & 21.88 & & 194 & 0.63 \\
June05 & 513 & 13.75 & & 257 & 2.66 \\
March04 & 333 & 5.05 & & 123 & 0.00 \\
March05 & 353 & 10.71 & & 163 & 0.16 \\
May04 & 400 & 5.42 & & 193 & 0.25 \\
May05 & 385 & 5.18 & & 192 & 1.21 \\
September04 & 497 & 7.78 & & 164 & 2.56 \\
\hline
\end{tabular}


Table 9. ANOVA results table of square-root transformed consumption by site type with weight and temperature included as covariates.

\begin{tabular}{llccc}
\hline Season & Effect & df & F-value & $\mathrm{p}$ \\
\hline Spring & Overall model & 4 & 6.39 & $<0.0001$ \\
& Site type & 2 & 9.39 & 0.0001 \\
& Weight & 1 & 0.22 & 0.6364 \\
Summer/Fall & Temperature & 1 & 4.35 & 0.0378 \\
& Overall model & 4 & 8.31 & $<0.0001$ \\
& Site type & 2 & 14.11 & $<0.0001$ \\
& Weight & 1 & 3.57 & 0.0596 \\
\multirow{3}{*}{ Winter } & Temperature & 1 & 3.11 & 0.0786 \\
& Overall model & 4 & 8.20 & $<0.0001$ \\
& Site type & 2 & 8.50 & 0.0003 \\
& Weight & 1 & 3.63 & 0.0579 \\
& Temperature & 1 & 6.24 & 0.0131 \\
\hline
\end{tabular}


Table 10. Mean consumption by site type for each season. Means with different letters within each season are significantly different from each other following a square-root transformation of consumption.

\begin{tabular}{llcc}
\hline Season & Stream Classification & $\begin{array}{c}\text { Mean } \\
\text { Consumption } \\
\left(\mathrm{J} \mathrm{g}^{-1} \mathrm{~d}^{-1}\right)\end{array}$ & $\begin{array}{c}\text { Standard } \\
\text { Error }\end{array}$ \\
\hline Spring & Downstream & $58.03^{\mathrm{A}}$ & 5.47 \\
& Midstream & $62.95^{\mathrm{A}}$ & 6.01 \\
& Upstream & $39.42^{\mathrm{B}}$ & 3.01 \\
Summer/Fall & Downstream & $24.88^{\mathrm{A}}$ & 2.60 \\
& Midstream & $25.74^{\mathrm{A}}$ & 3.50 \\
\multirow{3}{*}{ Winter } & Upstream & $13.13^{\mathrm{B}}$ & 2.43 \\
& Downstream & $8.89^{\mathrm{A}}$ & 1.38 \\
& Midstream & $5.61^{\mathrm{B}}$ & 0.79 \\
& Upstream & $11.12^{\mathrm{A}}$ & 1.03 \\
\hline
\end{tabular}


Table 11. Results of Chi-Square analysis of variation in diet composition by energy. Comparisons were made based on significant differences in mean consumption by site type (see Table 10).

\begin{tabular}{clccc}
\hline & & \multicolumn{3}{c}{ Likelihood Ratio } \\
Season & Site Type Comparison & df & Chi-Square & p \\
\hline Spring & Upstream * Midstream/Downstream & 8 & 48300 & $<0.0001$ \\
Summer/Fall & Upstream * Midstream/Downstream & 8 & 27741 & $<0.0001$ \\
Spring & Midstream * Upstream/Downstream & 8 & 12120 & $<0.0001$ \\
\hline
\end{tabular}


Figures

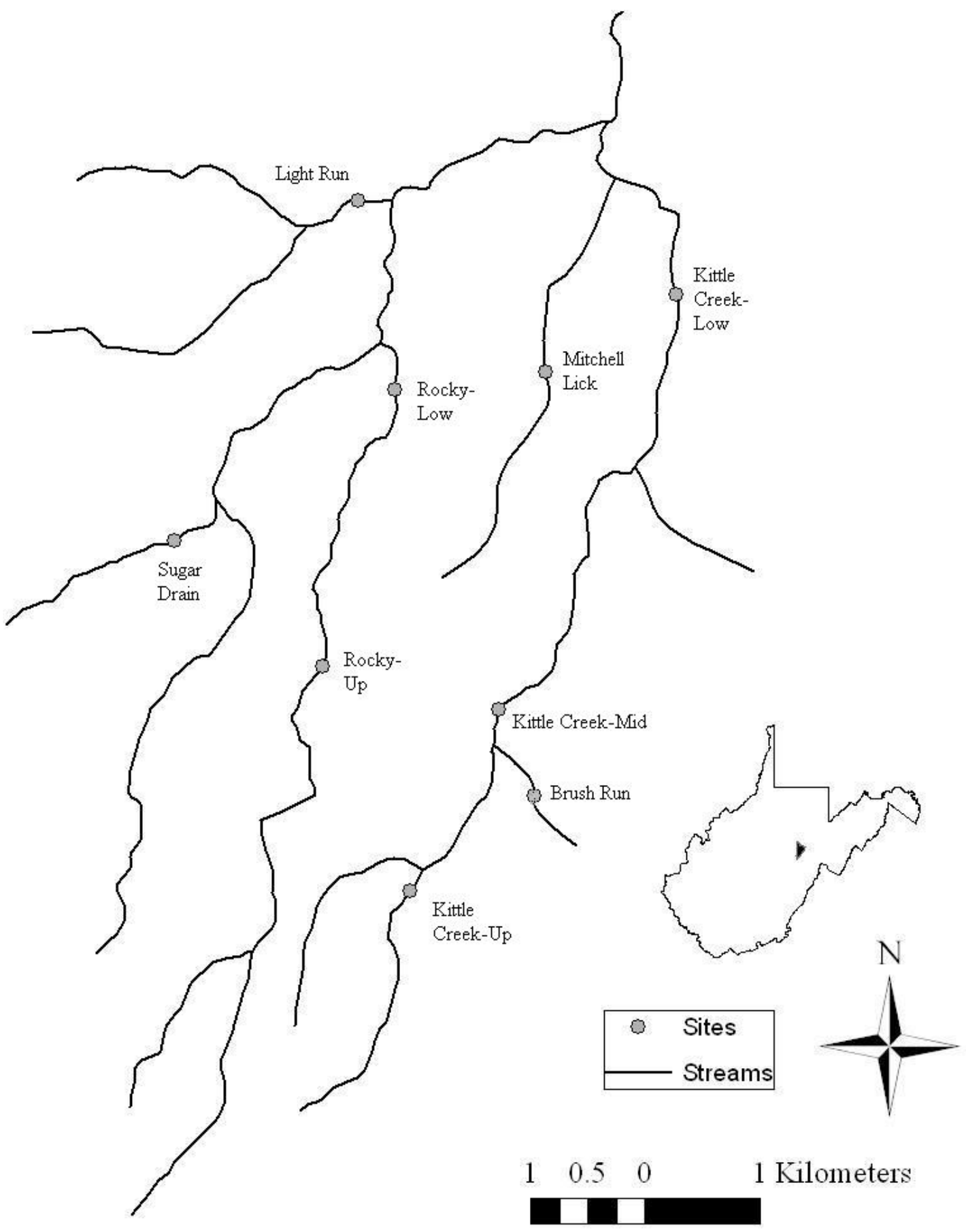

Figure 1. The upper Middle Fork watershed and all sites described for this study. 


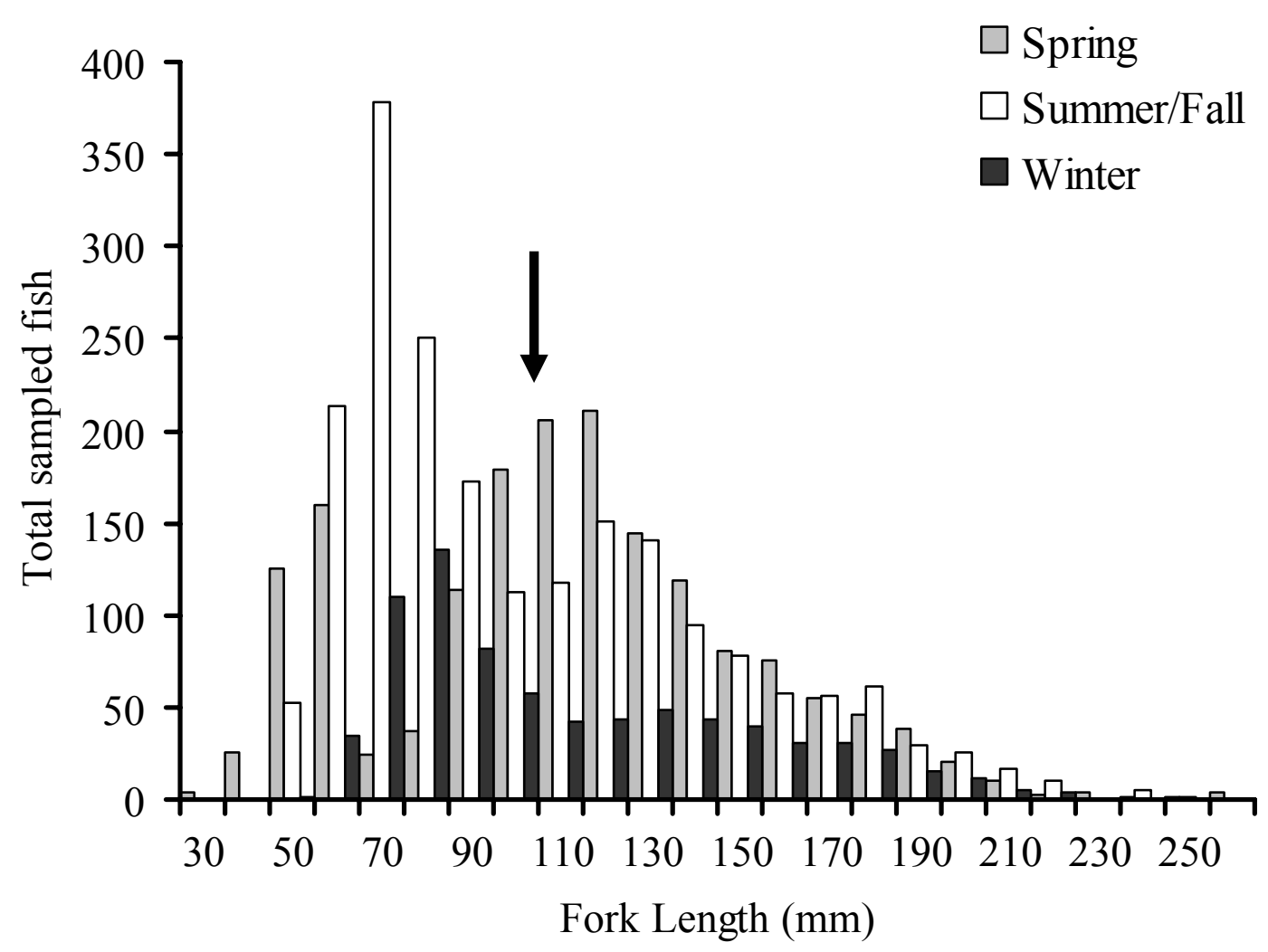

Figure 2. Distribution of fish size by total length across seasons. The arrow highlights the point at which fish where considered large enough to sample gut contents. 


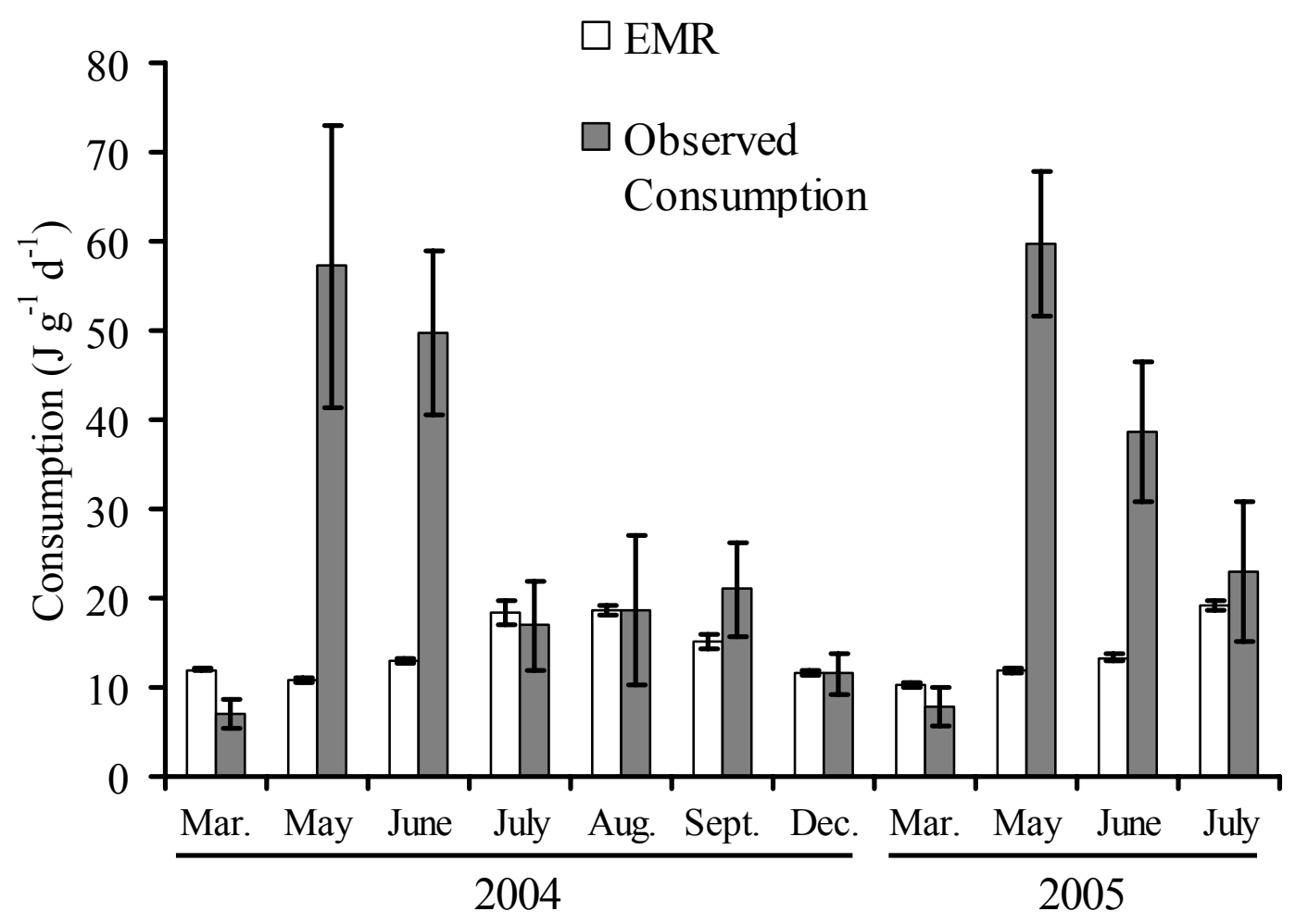

Figure 3. Mean ( $\pm 95 \%$ confidence intervals) monthly estimated maintenance ration (EMR) and observed consumption values across all sites. 


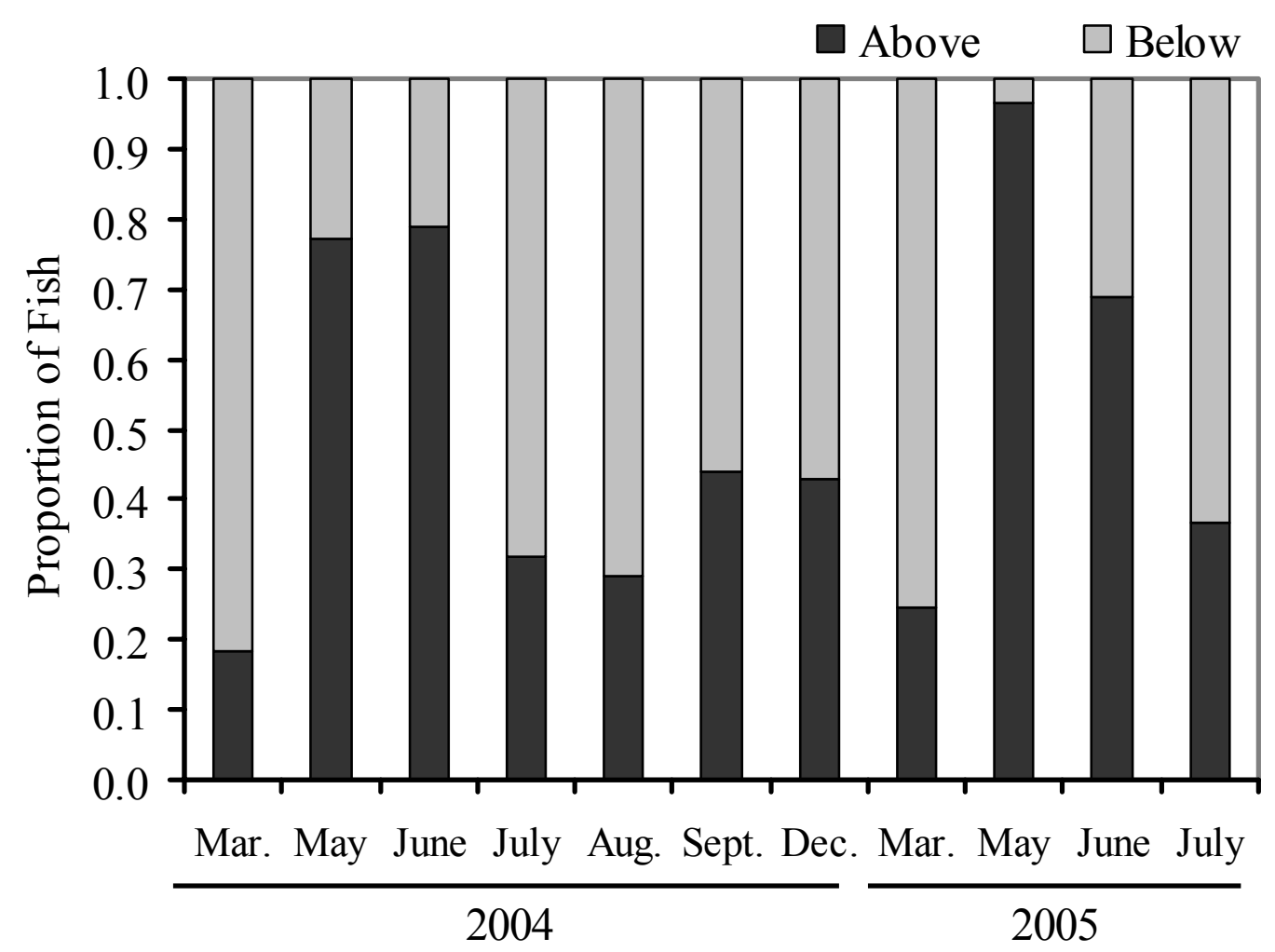

Figure 4. Proportions of fish eating above and below maintenance ration during each period of sampling. 

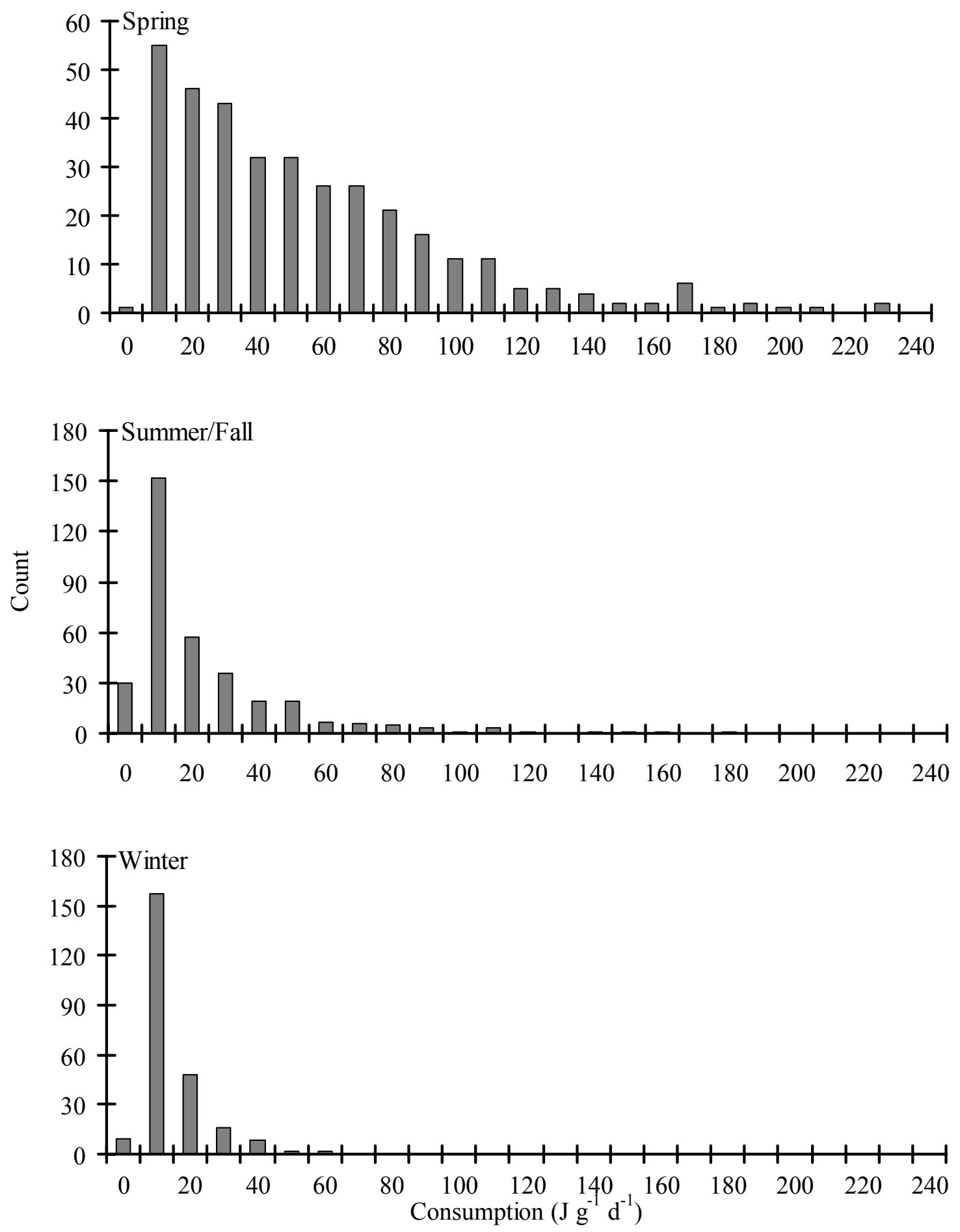

Figure 5. Frequency histograms of fish consumption estimates for each season. 

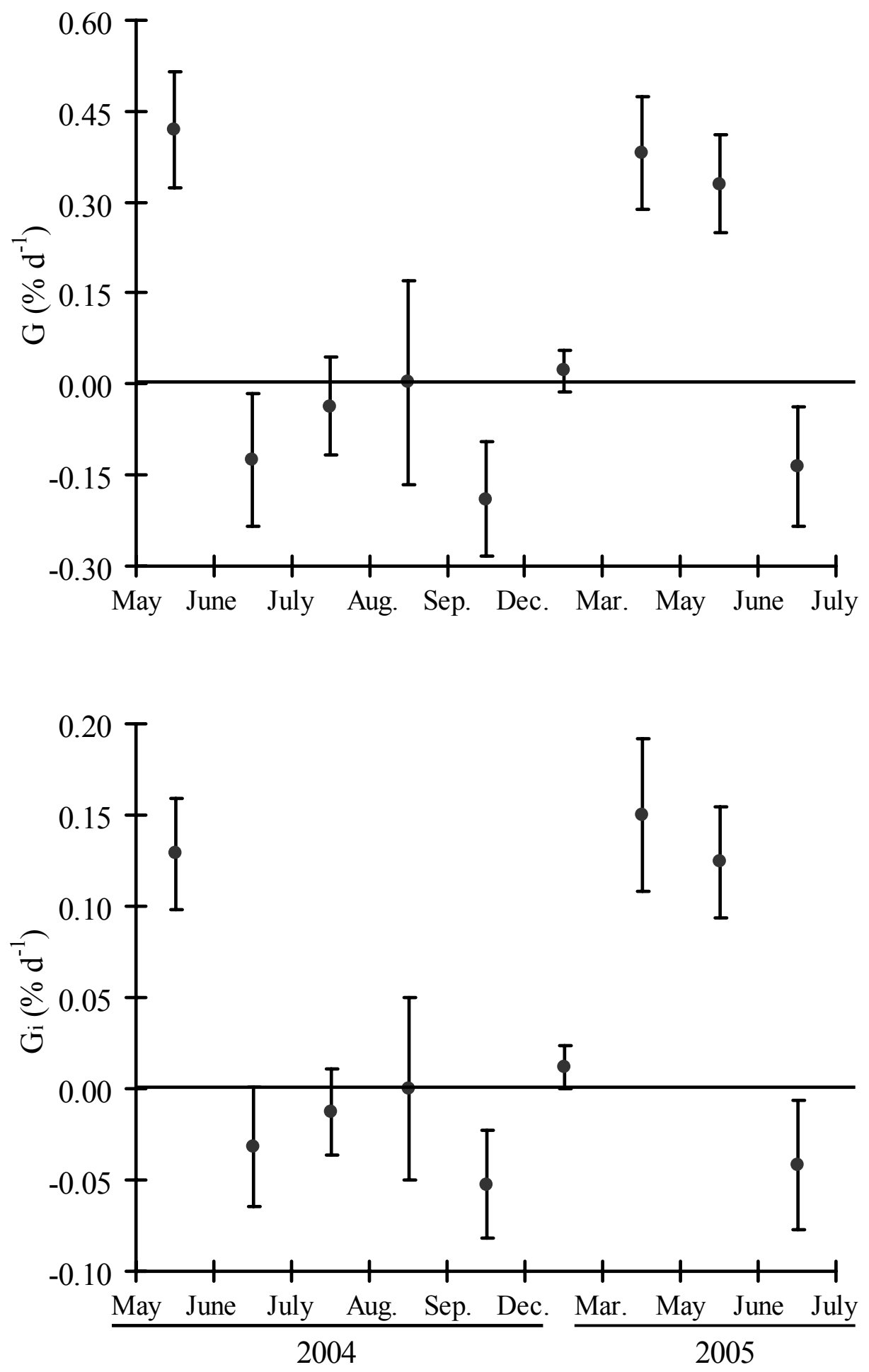

Figure 6. Mean ( $\pm 95 \%$ confidence intervals) total growth $(G)$ and size-adjusted growth (Gi) observed during the duration of the study. Note that not all intervals of time are equal in duration. 

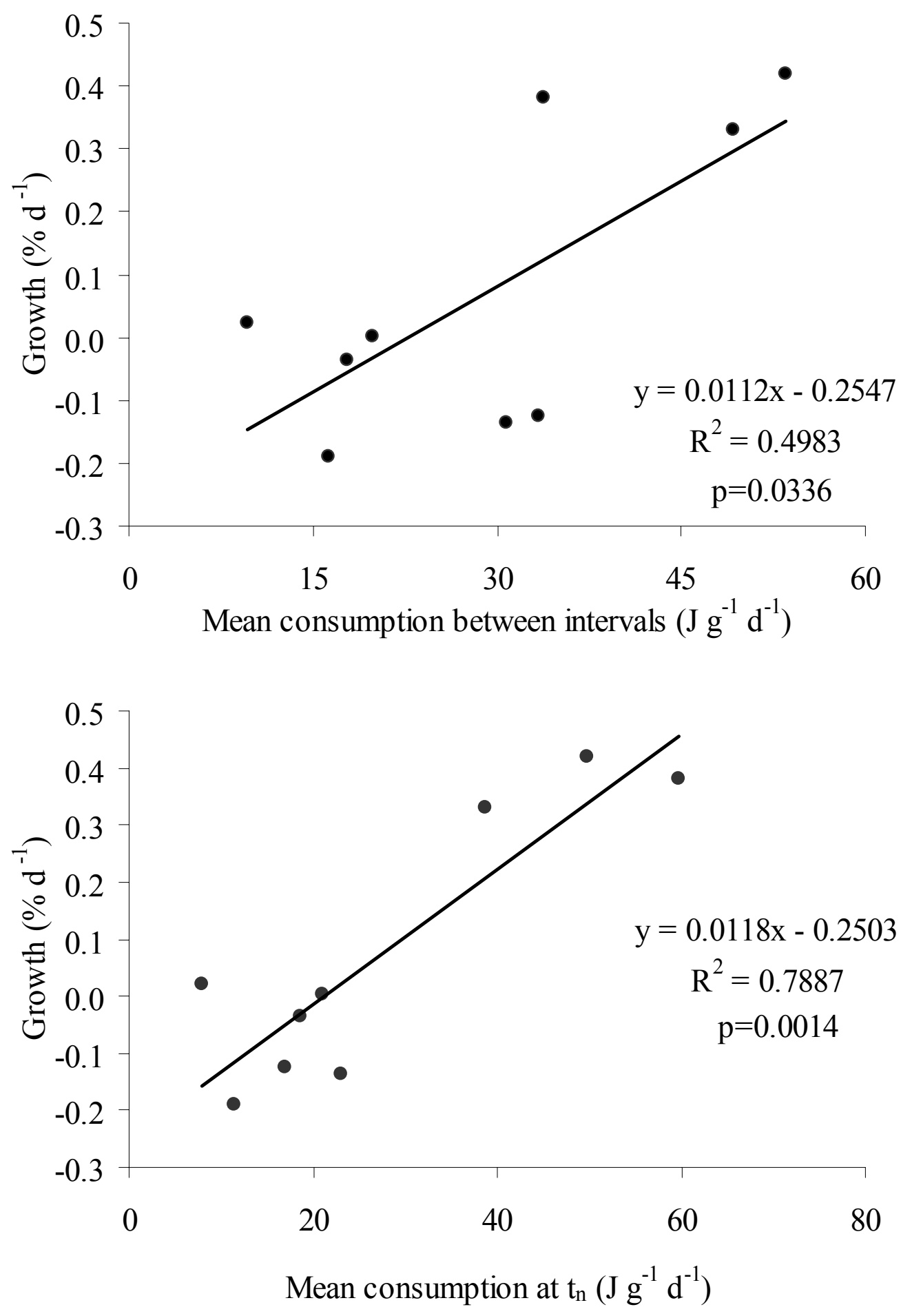

Figure 7. Results of linear regression between monthly growth and mean consumption between corresponding growth intervals (top graph) and consumption at $\mathrm{t}_{\mathrm{n}}$ (bottom graph). 


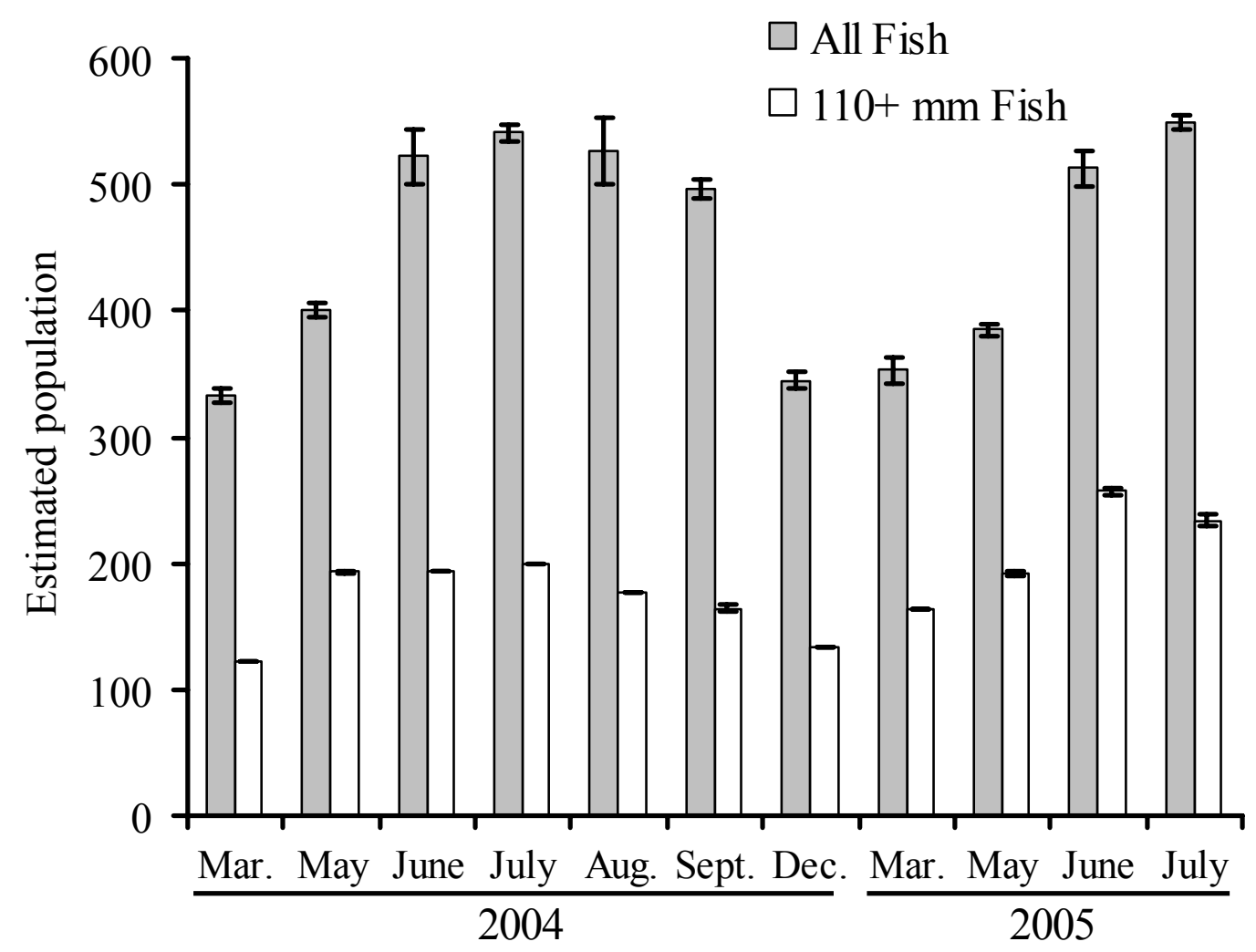

Figure 8. Population ( \pm standard error) estimates of all fish and fish eligible for gut content analysis across all sampling periods. Estimates represent the population of all $200 \mathrm{~m}$ sites combined. 

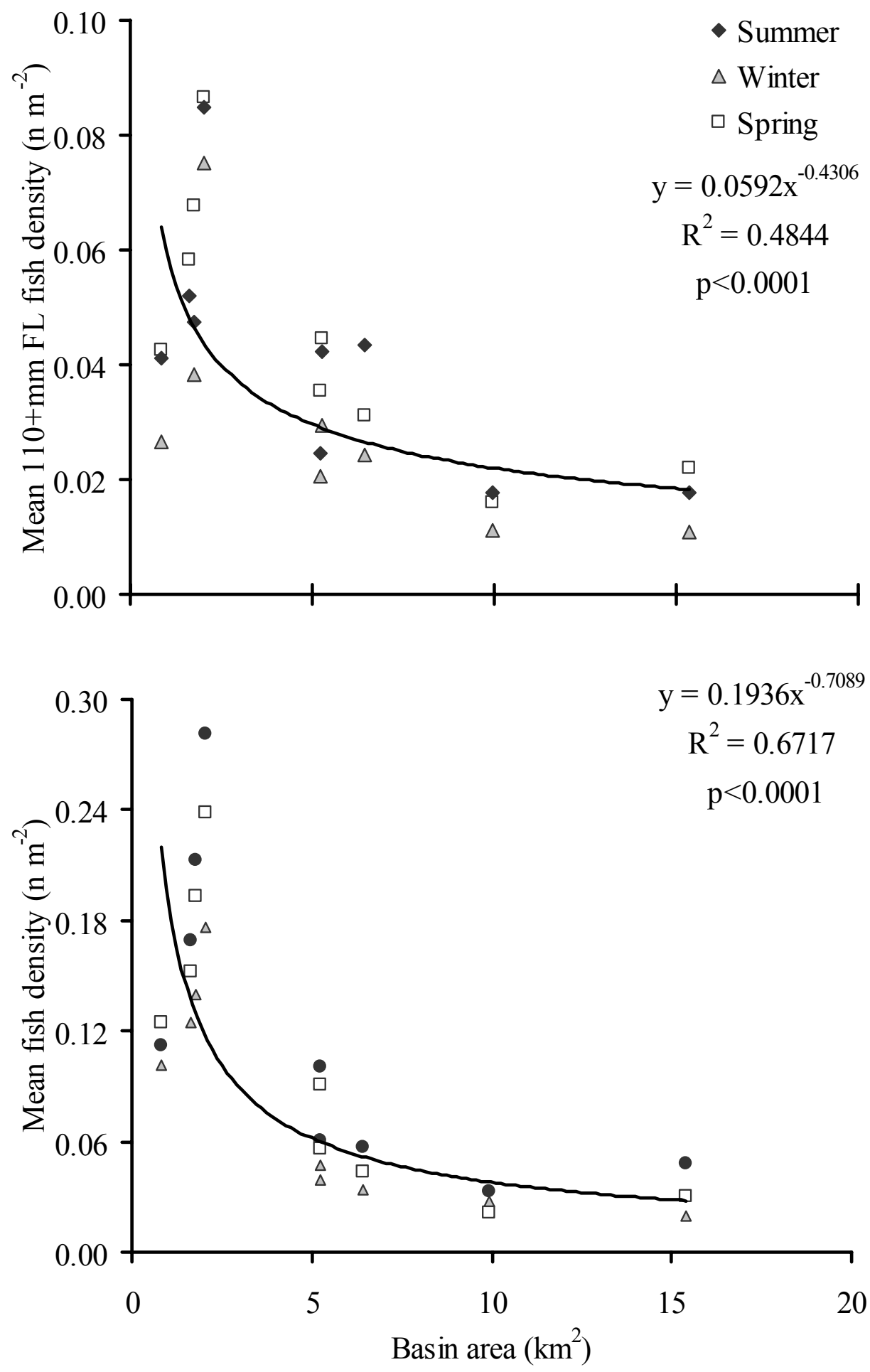

Figure 9. Fish densities as a function of basin area across all seasons. The upper graph illustrates fish eligible for gastric lavage $(110 \mathrm{~mm}+\mathrm{FL})$; the bottom graph depicts all fish. 

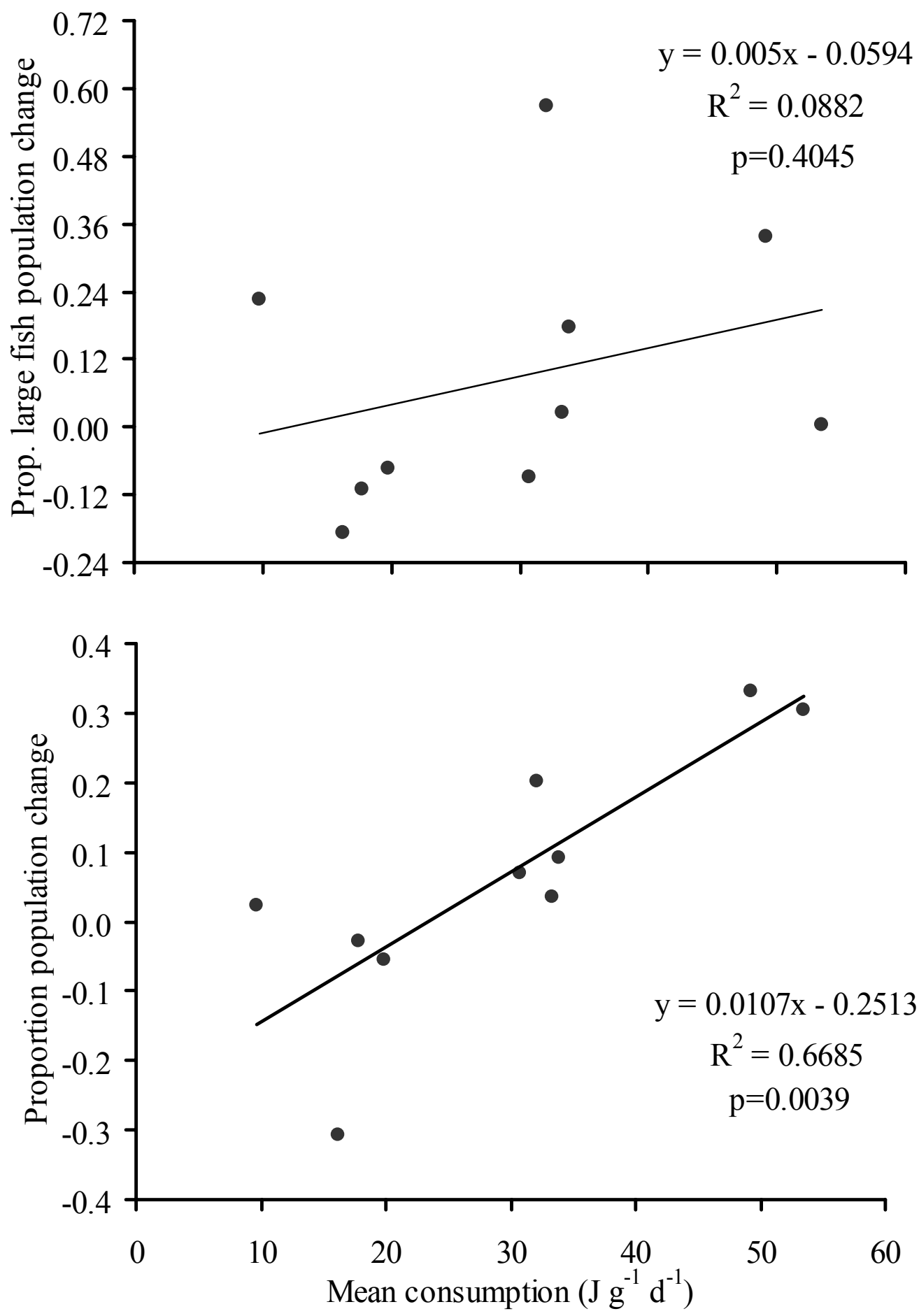

Figure 10. Results of linear regression analysis between monthly brook trout population change and mean consumption. The upper graph represents the size class of fish suitable for gastric lavage, the bottom graph represents all fish. 


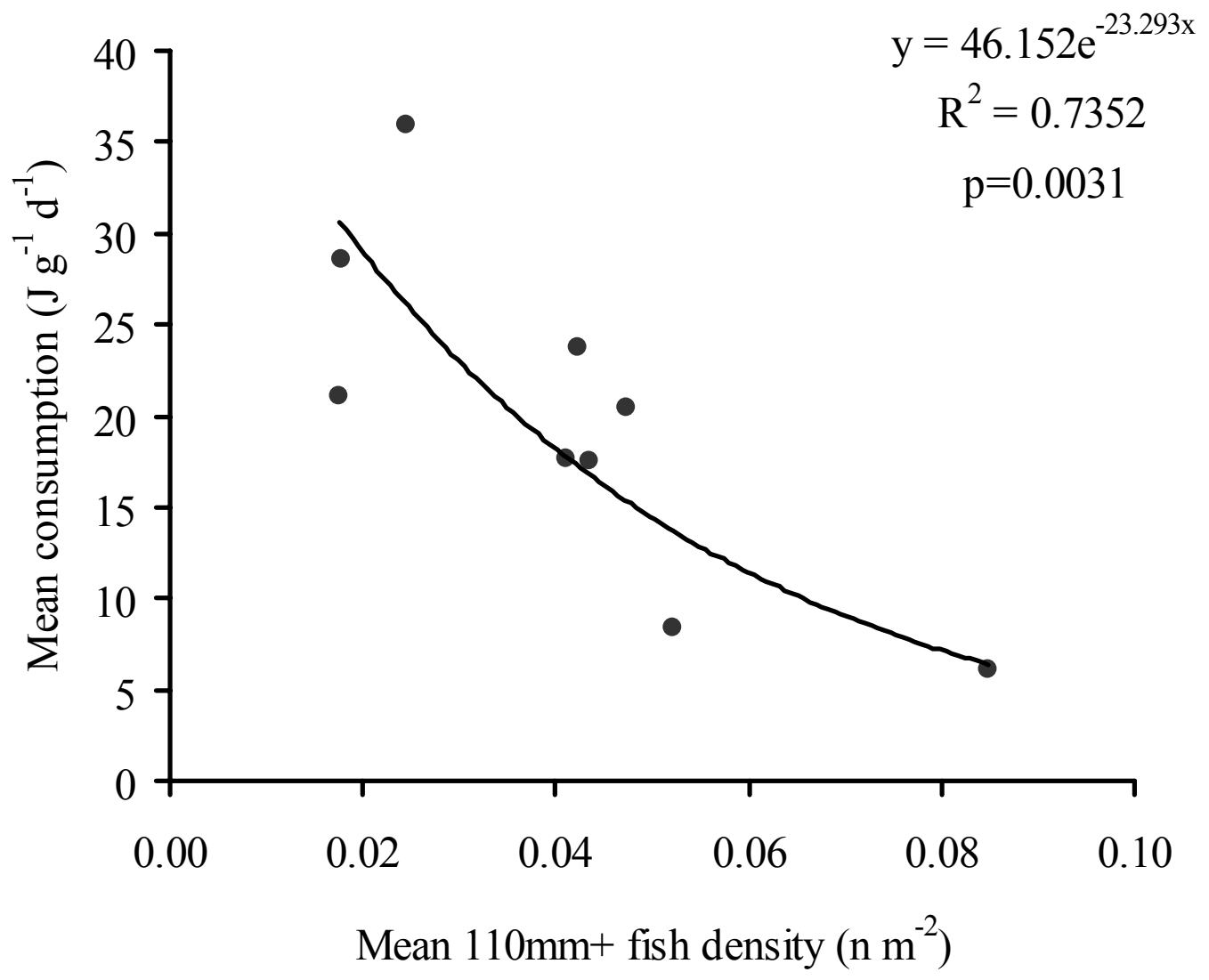

Figure 11. Mean consumption as a function of mean fish density during the summer and fall. Each point represents a site. 

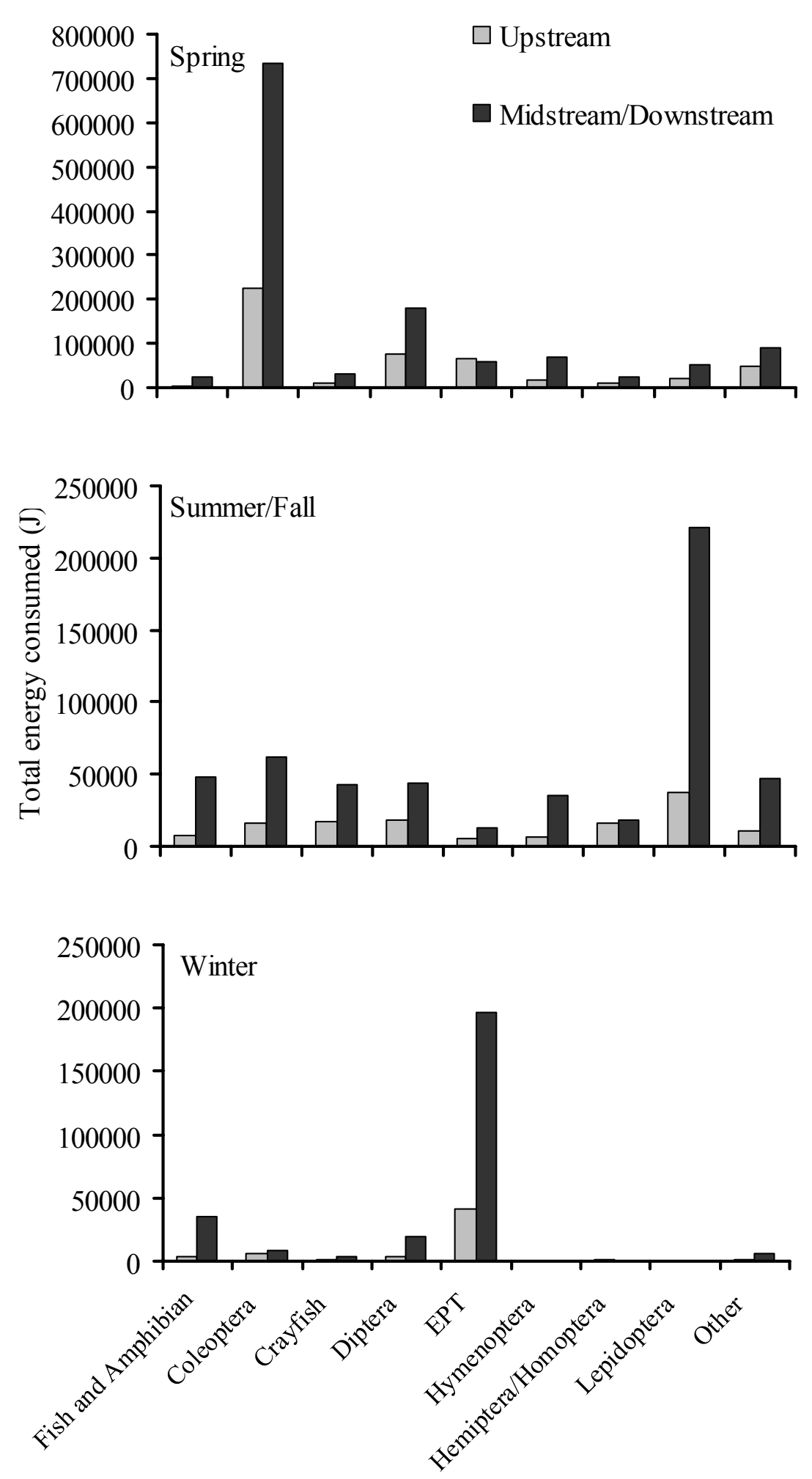

Figure 12. Distribution of energy sources by taxa between site types during each season. Comparisons were made based on significant differences in mean consumptions between site types (EPT=Ephemeroptera, Plecoptera, Trichoptera). Site types with black bars represent sites with significantly higher consumption rates. 


\section{Chapter 3: Temporal change in successful feeding of an Appalachian brook trout population.}

Abstract- Salmonids in headwater systems exploit a variety of prey items during different seasons. During some periods of the year, brook trout (Salvelinus fontinalis) in Appalachia may experience stressful feeding conditions due to high temperatures and low food availability. Feeding parameters of a population of brook trout in central Appalachia were monitored over the course of two years in order to quantify overall feeding trends and to identify the importance of various prey items. Brook trout exhibited generalist feeding during all seasons. Prey diversity was lowest during the winter and peaked in the spring, though significant differences in diversity measures were observed within seasons and with months across years. Fish feeding above maintenance ration exploited a greater diversity of prey items than fish feeding below maintenance ration, suggesting that employing a generalist feeding pattern helps sustain individuals. Within each season specific prey taxa were exploited at significantly different rates by fish feeding above maintenance ration compared to those feeding below maintenance ration. Specifically, some terrestrial insect taxa contributed more energy to fish eating above maintenance ration during spring and summer. During fall and winter, large organisms, such as crayfish and vertebrate prey, contributed disproportionately more energy in fish feeding above maintenance ration. Findings in this study imply that terrestrial organisms are more important than aquatic organisms in sustaining brook trout populations during warmer months. Further, specific terrestrial taxa may be more important than others, and future examinations of headwater salmonid diets should consider taxonomic detail in terrestrial organisms and the relationship between terrestrial organisms and the riparian vegetation state. 


\section{Introduction}

Lotic salmonids frequently inhabit environments of low productivity, such as headwater streams. Consequently, the quality and quantity of food intake may play an important role in shaping salmonid populations. The most frequently cited source of energy for salmonids in such ecosystems is the aquatic macroinvertebrate community (Allan 1980, Neveu 1999), which derives most energy from allochthonous sources in the surrounding watershed (Vannote et al. 1980). Such sources of energy often result in stream communities low in productivity and thus offer limited resources to higher trophic levels, such as stream fish (Cada et al. 1987). However, recent surveys in Japanese streams have indicated that terrestrial invertebrates may play a dominant role over aquatic sources in providing energy to salmonids (Nakano et al. 1999, Kawaguchi and Nakano 2001). This idea is not new to stream fish ecology, as Allan (1951) noted that terrestrial input to streams often allowed fish biomass to persist above the capacity provided by the aquatic prey community. Nevertheless, studies which examine the specific importance of individual prey taxa (either terrestrial or aquatic) to lotic salmonids during episodes of low prey availability are rare.

Brook trout (Salvelinus fontinalis) in Appalachia occupy environments of low productivity and populations may be shaped by feeding dynamics (Cada et al. 1987 Ensign et al. 1990). Particularly, feeding rates drop from spring to summer and brook trout may be subjected to prolonged periods of feeding at or below maintenance ration (Ensign et al. 1990, Sweka 2003, Chapter 2 of this thesis). Studies of stream salmonids have concluded that drops in feeding rates during stressful times are caused by decreasing rates of drift (Ensign et al. 1990, de Crespin de Billy 2002). These periods have been 
shown to affect brook trout population dynamics. Such episodes of low feeding rates may affect emigration, recruitment of fish into larger size classes, and mean growth rates (Chapter 2).

Bioenergetics models may be employed to elucidate details in feeding patterns. With a bioenergetics model, one may use variables such as fish size, temperature, and prey and predator energy densities to determine the minimal amount of energy required to maintain body weight (Elliot 1976, Sweka and Hartman 2001). This value is termed maintenance ration $\left(\mathrm{C}_{\text {main }}\right)$ and may be compared to an observed rate of daily ration $\left(\mathrm{C}_{24}\right)$, which is calculated using observed stomach contents and the gastric evacuation rate (Eggers 1977). Comparing $\mathrm{C}_{24}$ to $\mathrm{C}_{\text {main }}$ allows individual fish to be classified as eating either above or below maintenance ration (Hayward and Margraf 1987, McKinney and Speas 2001). Such comparisons allow analyses of dietary trends in fish eating above and below maintenance ration to make inferences on successful feeding strategy.

A detailed understanding of the feeding strategy of brook trout could improve our understanding of stream salmonid ecology. Particular prey organisms may be important in supporting fish during periods of low productivity or driving growth rates during periods of abundant food resources. Although considerable literature exists examining brook trout diet patterns, many examined only particular seasons and most categorized all terrestrial prey taxa into one group (Cada et al. 1987, Thonney and Gibson 1989, Ensign et al. 1990, Forrester et al. 1994, Bridcut and Giller 1995, Mookerji et al. 2004). However, when the taxonomic detail of terrestrial organisms is considered, studies have found that some taxa may be of particular importance while others negligible as energetic input to aquatic ecosystems (Wipfli and Gregovich 2002) or fish diet (Webster and 
Hartman 2005). Objectives in this study were to: (1) determine the overall feeding strategy of brook trout over the course of the year in a central Appalachian watershed, (2) quantify the temporal differences in aquatic and terrestrial prey consumption, and (3) identify if the feeding patterns of fish feeding above maintenance ration differ from fish feeding less successfully.

\section{Methods}

\section{Study Area}

The study was conducted within the Middle Fork watershed, a north flowing tributary of the Tygart River in the central Appalachian Mountains of Randolph County, West Virginia. The majority of land cover within the watershed is that of secondary growth hardwood deciduous forest. All sites in the study are located in the southernmost extent of the watershed (Figure 1) and are of low order and high gradient. Nine-200 m sites were selected based on a number of criteria: each site contained a resident brook trout population, consistently supported age-0 brook trout (suggesting chemical conditions were suitable enough for spawning), and was devoid of fish barriers between other sites. Temperature regimens in these reaches are suitable for trout; temperature rarely exceeded $20^{\circ} \mathrm{C}$ through the duration of the study. The West Virginia Division of Natural Resources and the West Virginia Department of Environmental Protection have actively added limestone sand to riparian areas of streams within the watershed to remediate the effects of acid precipitation and acid mine drainage in the Middle Fork since the 1990's (WVDNR 2001). This process is commonly used in the region and successfully increases $\mathrm{pH}$, restores fish communities, and increases invertebrate abundance (Clayton et al. 1998). Some sites selected in this study were not actively 
treated with lime (Sugar Drain, Light Run and Brushy Run). However, each site without a limestone treatment retained the ability to support brook trout spawning and carry fish populations.

Fish diversity differed across sites but was typical of Appalachian headwater systems. The number of species encountered increased with stream size; however, in nearly all sites fish fauna was dominated by brook trout and mottled sculpin (Cottus bairdi). Other fish sampled include blacknose dace (Rhynichthys obtusis), longnose dace (R. cataractae), creek chub (Semotilus atromaculatus), white sucker (Catostomus commersoni), northern hogsucker (Hypentelium nigricans), and fantail darter (Etheostoma flabellare).

\section{Fish and Habitat Sampling}

Fish sampling occurred eleven times over the course of two years (Table 1). All sampling events were divided into four seasons based on similarities in mean consumption estimates and temperature for some statistical analyses (Table 2). Sampling was conducted between 0800 and $1600-\mathrm{hr}$ and the order of sites to sample were randomly chosen during each day. A three-pass electrofishing procedure (Platts and Nelson 1988) was used to estimate fish populations within the $200 \mathrm{~m}$ section. Before sampling, block nets were placed at the top and bottom of each section to restrict fish movement in or out of sections during sampling. Sampling teams used an electrofishing unit (Smith-Root, DC, $60 \mathrm{hz}, 500-750 \mathrm{~V}$, Vancouver, WA) and dip nets to capture fish.

Following collection, fish were processed at a streamside station. All fish were immobilized with a clove oil and $95 \%$ ethanol solution. Brook trout were weighed to the nearest $0.5 \mathrm{~g}$, and total length was taken to the nearest $\mathrm{mm}$. A subset of 10 brook trout 
per site per month was chosen for stomach content removal. Only fish $>110 \mathrm{~mm}$ fork length were considered eligible for gut content removal due to gear restrictions; the tube used in flushing water into the gut was usually larger than the gape of fish below this size (7 mm diameter). However, the fish that were analyzed generally represented age 1-and older fish as is apparent in length frequency histograms (Figure 2). An attempt was made to collect an equal range of fish sizes to analyze for gut content at each site. Stomach contents were removed by directing a constant flow of stream water into the foregut until all items had been apparently collected (Twomey and Giller 1990). Gut items were filtered with a $250 \mu \mathrm{m}$ sieve and transferred to $95 \%$ ethanol. This process of collecting stomach contents has proven very effective in removing gut contents (Light et al. 1983) and analysis with the gear used in this study has found that the technique is acceptably efficient (Sweka 2003). A sample of 10 trout was randomly selected from sites, frozen, and kept for analysis of fish dry weight during select sampling periods. Dry weight estimates were needed in order to calculate an estimate of fish energy density, a necessary component of bioenergetics analyses conducted in this study (described below).

\section{Laboratory Procedures}

All prey items were identified to the Family level or the lowest taxonomic classification possible (Merrit and Cummins 1996, Borror et al. 1989). Extremely small organisms ( $<0.5 \mathrm{~mm}$ length) or organisms partially destroyed beyond identification to Family were classified to Order. The lengths of prey items were measured via an ocular micrometer to the nearest $0.1 \mathrm{~mm}$; when lengths were unavailable head capsules widths were measured to the nearest $0.1 \mathrm{~mm}$. Crayfish (Cambarus bartonii) carapace lengths 
were measured rather than head capsule width or body length. The dry mass of each organism was estimated using published length- or head width-dry mass equations, with the exception of crayfish where a carapace-dry mass equation was used (Sample et al. 1993, Benke et al 1999, Johnston and Cunjak 1999, Sabo et al. 2002). Vertebrate food items, such as frogs, salamanders, and fish were dried at a temperature of $60^{\circ} \mathrm{C}$ for 48 -hr to calculate dry weight. Each prey item was further classified as either aquatic or terrestrial, with aquatic organisms possessing a life stage with an obligate aquatic phase. Therefore, adult aquatic insects, such as Ephemeroptera, were classified as aquatic (Sweka 2003). Frozen brook trout were thawed, weighed to the nearest $0.1 \mathrm{~g}$, and dried at a temperature of $60^{\circ} \mathrm{C}$ for 72 -hr for dry weight and energy density analysis.

\section{Estimates of Consumption and Daily Ration}

Calculations were made to approximate brook trout maintenance ration and observed consumption. Both variables allowed analyses of trends in consumption and the comparison of feeding habits of fish eating above and below maintenance ration. Maintenance rations (in Joules per gram of fish wet weight per day) were calculated based on a bioenergetics model for brook trout (Hartman and Sweka 2001) and used fish weight, fish and prey energy densities, and observed water temperature as variables. Energy densities were calculated from either observed mean energy density in collected fish using dry weight-energy equation for Salmonidae (Hartman and Brandt 1995) or interpolated from energy densities taken before and after a given collection period. Mean fish energy density was assumed to be equal across sites during a given month (see Chapter 2 for fish energy density and temperature variables). Such variables were applied to the brook trout bioenergetics model and maintenance ration was calculated by 
determining the energy required to maintain zero growth over the course of one day. Each prey item was converted to energy using dry weight-energy equations (Cummins and Wuycheck 1971), and the total energy in the gut was summarized for each fish.

The total energy intake was multiplied by the brook trout gastric evacuation rates (based on temperature, Sweka et al. 2004) and divided by fish weight to calculate an observed consumption value $\left(\mathrm{J} \mathrm{g}^{-1} \mathrm{fish} \mathrm{h}^{-1}\right)$ as suggested by Eggers (1977). This estimate was multiplied by 24 to convert it to a daily ration. The mean daily consumption estimates in this study were based on stomach contents obtained during the daylight hours only. Though daily consumption typically requires estimates of feeding activity across a diel cycle (Bowen 1996), multiple studies of indigenous brook trout feeding trends revealed no significant diel pattern in multiple diet variables (Forrester et al. 1994, Sweka 2003, Mookerji et al. 2004). Further, the evacuation rate of brook trout has proven to be low relative to other salmonids (Sweka et al. 2004), meaning food items remain in the gut long after they have been ingested. Thus the study made the assumption that a measurement of diet during daylight hours provided sufficient data to calculate mean feeding conditions for the corresponding season.

\section{Statistical Analyses}

In order to determine the overall feeding strategy of all fish during each season, a graphical method first proposed by Costello (1990) and later modified by Amundsen et al. (1996) was employed. With this analysis, percent frequency of occurrence $\left(\% \mathrm{~F}_{\mathrm{i}}\right)$ of a given prey item is calculated with the following equation:

$$
\% \mathrm{~F}_{\mathrm{i}}=\left(\mathrm{N}_{\mathrm{i}} / \mathrm{N}\right) * 100
$$


where $\mathrm{N}_{\mathrm{i}}$ is the number of trout with prey $i$ in their stomach and $\mathrm{N}$ is the total number of fish with food present in stomachs. This value is placed on the $\mathrm{x}$-axis and plotted against prey-specific abundance $\left(\% \mathrm{P}_{\mathrm{i}}\right)$ :

$$
\% \mathrm{P}_{\mathrm{i}}=\left(\sum \mathrm{S}_{\mathrm{i}} / \sum \mathrm{S}_{\mathrm{t}}\right) * 100
$$

Where $\mathrm{S}_{\mathrm{i}}$ is the energy of prey $i$ in a stomach and $\mathrm{S}_{\mathrm{t}}$ is the total energy content of stomachs that contain prey $i$. With a graph of all prey categories, inferences may be made on prey importance and variation in feeding strategy. All prey items were classified first into source (aquatic or terrestrial) and then taxonomic order. Prey categories that comprised simultaneously $<5 \%$ by frequency of occurrence and $<5 \%$ by prey-specific abundance were placed into an aquatic or terrestrial 'rare item' category. This graphical analysis was conducted for each season in order to quantify temporal trends in feeding strategy.

Measures of prey diversity within each fish were calculated in order to further quantify feeding strategy. While measures of diversity in diet studies have been criticized for failing to define 'high' diversity (Chipps and Garvey in press), diversity variables have been successfully employed in defining feeding strategies within a population (Bridcut and Giller 1995). Two diversity measures (each using family as the lowest taxa) were calculated for each stomach with food items present: total number of families and Shannon's reciprocal index (1/D, Krebs 1994). Means of both measures were calculated for each month and tested for differences between months using repeated measures analysis of variance (ANOVA) and Duncan's repeated measures post-hoc.

Consumption estimates by origin (aquatic or terrestrial) were calculated separately in order to determine if fish were deriving a majority of energy from either 
source. Mean consumption values were calculated for both prey categories. A t-test was run on the means between aquatic and terrestrial consumption for each month to determine if one category was significantly higher than the other.

In order to determine if specific feeding strategies affected whether or not a fish was eating above or below maintenance ration, all fish with stomach contents present were classified as either above or below maintenance ration for use in several analyses. Fish were placed into the 'above maintenance ration' category if the observed consumption exceeded maintenance ration. The means of both diversity indices were calculated for both groups and tested for significant differences using a t-test within each season. Differences in consumption of specific prey items were tested between fish eating above and below maintenance ration. For this analysis, prey categories were derived by classifying all organisms first by origin (aquatic or terrestrial) and then by taxonomic Order. Because of the high diversity of prey exploited by brook trout, further categorization of prey items was necessary for analysis. Within each season, the highest four orders by count and the highest four by energy were selected for analysis. All remaining prey items that did not fall into the first eight prey categories were placed into a broad aquatic or terrestrial 'other' category. As a result, each prey item consumed by brook trout fell into one of ten categories defined by order and origin. The first eight prey categories selected (those not classified as 'other') represented between $80-95 \%$ of prey by count and energy within a season. While differences likely existed in the exploitation rates of different prey organisms between sites (Chapter 2), this study was concerned with the general nature of successfully feeding fish throughout the watershed. Therefore, differences in feeding rates between sites were not considered. 
Statistical analyses were performed on proportional prey values as suggested by Somerton (1991). The proportional energy derived from each of the ten prey categories was calculated for each fish within a season. These proportions were first square-root and then arcsine transformed to approximate normality. A multivariate analysis of variance (MANOVA) was performed on the transformed proportions to test for differences in proportional prey exploitation between fish eating above and below maintenance ration. Because two groups were being compared, Hotelling's $\mathrm{T}^{2}$ statistic was to determine if a statistical difference in exploitation existed between fish eating above and below maintenance ration. If such an overall significant difference existed, differences in exploitation rates of specific prey were tested. An empirical probability distribution was computed by randomly sorting all transformed proportions of a given prey item into equal sized samples as the original data and computing a t-statistic with 5000 repetitions. Following the randomization procedure, a t-test was performed on the transformed proportions of fish above and below maintenance ration. The t-statistic was then compared to the empirical probability distribution to determine significance. Because these tests were preformed a posteriori, the $\alpha$-level was adjusted using the Bonferroni correction. Ten prey categories per season were tested, consequentially, differences were considered significant at $\alpha=0.005$.

\section{Results}

\section{Overall Feeding Strategy}

The brook trout population typically exhibited a generalist feeding pattern with little variation between seasons (Figures 3 and 4). Most prey types fell on the low end of the prey-specific abundance scale. However, a few rare taxa dominated content when 
consumed and consequentially scored high in prey-abundance for the particular fish that contained them. These were large food items, such as fish (cyprinids, cottids, and juvenile brook trout), salamanders (Caudata: Plethodontidae) and cockroaches (Blattaria). During each season a number of taxa were observed at high frequencies but did not consistently score high in abundance, such as beetles (Coleoptera) during the spring and caddisfly larvae (Trichoptera) during the winter. No single dominant taxa (high in both frequency and prey-specific abundance) emerged during any season. See Appendix A for detailed information of consumption by taxa.

Prey diversity varied significantly between and within seasons by both mean number of families $(\mathrm{df}=10, \mathrm{~F}=66.5, \mathrm{p}<0.0001)$ and the reciprocal of Shannon's diversity index $(\mathrm{df}=10, \mathrm{~F}=18.09, \mathrm{p}<0.0001$, Table 3 and Figure 5$)$. Diversity by both variables was highest during spring and lowest during winter. Both measures of diversity were occasionally significantly variable within seasons, and occasional significant differences existed between the same months of different years.

Consumption estimates by origin of prey varied significantly with seasonal change. Terrestrial prey consumption significantly exceeded aquatic prey consumption during all months aside from winter (Table 4 and Figure 6). Specifically, terrestrial prey consumption peaked in May and declined with the arrival of summer. During the winter months, terrestrial prey consumption fell to near zero and aquatic prey significantly exceeded terrestrial energy input. Over the course of the study, terrestrial prey consumption varied on a greater scale than aquatic prey consumption. 


\section{Strategy and Consumption in Relation to Maintenance Ration}

Whether or not a fish consumed energy above maintenance ration was related to seasonal change and prey diversity variables. Fish feeding above maintenance ration represented the minority of individuals during all seasons except spring (Table 5). Measures of prey diversity per fish were significantly different between individuals eating above and below maintenance ration. Specifically, mean prey families per individual fish was significantly higher in fish eating above maintenance ration during all seasons (Table 6) while the reciprocal of Simpson's diversity index was significantly higher in fish eating above maintenance ration during the summer (Table 7).

The results of a MANOVA test on proportional prey by energy showed that during each season whether or not a fish was feeding above or below maintenance ration was significantly related to exploitation of particular prey taxa (Table 8). Differences between fish feeding above and below maintenance ration in particular prey exploitation rates varied with seasonal change (Table 9). Throughout spring, fish feeding above maintenance ration fed on a significantly higher proportion of terrestrial Coleoptera and significantly less terrestrial Hemiptera/Homoptera and aquatic Trichoptera. Fish feeding above maintenance ration through the summer fed on a significantly higher proportion of terrestrial Coleoptera and Lepidoptera. During fall, fish feeding above maintenance ration exploited terrestrial Lepidoptera at a significantly higher proportion. All fish that fed on crayfish were calculated as feeding above maintenance ration during the fall, preventing a statistical comparison of crayfish proportions between groups of fish. Vertebrate taxa (fish and salamanders) during the winter were consumed at a significantly higher proportion by fish eating above maintenance ration. Trichoptera dominated winter 
consumption, contributing $>50 \%$ of energetic input for both groups of fish, though no significant difference in Trichoptera exploitation existed between groups of fish.

\section{Discussion}

\section{Temporal Strategy}

Brook trout in the upper Middle Fork River exhibited generalist feeding across all sampled seasons despite a drop in available prey items during the winter. This contrasts observed strategies of other salmonid populations (Odenkirk and Estes 1991, Bridcut and Giller 1995, Wipfli 1997, Steingrimsson and Gislason 2002) including brook trout (Forrester et al. 1994), where a single or small number of prey taxa dominated diet by count and/or abundance. Other dietary studies have detected a more generalized feeding strategy (Allan 1981, Thonney and Gibson 1989). However, in most studies where terrestrial items appeared important, all such prey items were placed into a single category (Thonney and Gibson 1989, Forrester et al. 1994, Bridcut and Giller 1995). By categorizing all prey taxa with equivalent detail and observing diet shifts multiple times over the course of the year, observations in the current study suggest that the Middle Fork River brook trout population does not disproportionately feed on one particular prey order by weight and number during any season.

The examination of diversity in the current study allows limited, but potentially meaningful, comparisons to other studies. Prey diversity measures have received little attention in fish diet literature (Chipps and Garvey in press). While several papers have employed diversity to quantify diet (Tokeshi 1991, Bridcut and Giller 1995), the majority of dietary studies have reported varying levels of taxonomic detail. Salmonids may 
exploit as few as three to five genera in a particular season (McKinney and Speas 1991, Odenkirk and Estes 1991, Steingrimsson and Gislason 2002, Steinhart and Wurtsbaugh 2003). Others have reported a greater number of prey taxa in salmonid diets (Allan 1980, Thonney and Gibson 1989, Ensign et al. 1991, Forrester et al. 1994, Bridcut and Giller 1995, Wipfli 1997, Mookerji 2004). Direct comparison of findings in the current study to these studies is difficult, as differences in taxonomic detail exist. However, those that did identify taxa beyond Order could quantify the majority of diet by seven to twelve families (Allan 1981, Hubert and Rhodes 1989, Bridcut and Giller 1995). Considering that Middle Fork River brook trout exploited a mean of fifteen families in one season, fish observed in the current study likely exploit a higher diversity of prey taxa than most observed salmonid populations.

Variation in diet patterns between years may distort conclusions made about salmonid feeding trends. While the majority of salmonid diet studies observed one season or multiple seasons across one year, few have examined diets over the course of more than one year (but see Sweka 2003 and Thorne 2004). In the current study, significant differences were observed in diversity variables during the same month between 2004 and 2005. Limiting the study to one year would have led to less detailed conclusions on variation in diversity. Such variation between years suggests that Appalachian brook trout dietary components may not be annually consistent and may be linked to yearly variations in insect activity.

Terrestrial prey seems to be more heavily exploited by Middle Fork River brook trout than aquatic prey throughout a majority of the year. Several dietary studies have found terrestrial food items to be important (Allan 1981, Forrester 1994, Bridcut and 
Giller 1995), but studies showing terrestrial insects may significantly exceed aquatic prey sources in importance have been limited to Japanese streams (Kawaguchi and Nakano 2001, Kawaguchi et al. 2003) and one in central Appalachia (Sweka 2003). Findings in the current study show that terrestrial energy input consistently exceeds aquatic input during all but the winter months. Contrary to Japanese streams where terrestrial consumption peaked in summer (Kawaguchi et al. 2003), brook trout in the Middle Fork River consumed the largest amount of terrestrial energy during the spring and terrestrial insect consumption decreased as summer progressed yet remained greater than aquatic energy input.

\section{Components of Successful Feeding}

The dietary pattern employed by brook trout feeding above maintenance ration may explain why brook trout exhibit a generalist pattern. Fish feeding above maintenance ration contained a higher mean number of prey families per gut than those feeding below maintenance ration during each season. Therefore, exploiting a variety of prey types increased the chances of maintaining body weight during stressful times (summer) and increased the chances of growing during opportunistic conditions (spring). Exploitation of a range of prey organisms may increase the chances that one of the prey organisms is disproportionately large in size and therefore offers more energy. Considering the findings related to mean familial number, it is unclear why the diversity index was significantly different between fish eating above and below maintenance ration only during the summer. The summer months may be the most stressful to brook trout due to high temperatures and low food availability (Ensign et al. 1990, Sweka 2003, 
Chapter 2). Consequently, adopting a strategy of high generalization may be particularly important during these months.

The significantly different energetic proportions of taxa found between fish eating above and below maintenance ration may highlight disproportionately important prey items. During warmer months, terrestrial organisms (terrestrial Coleoptera during both seasons and terrestrial Lepidoptera during the summer and fall) were exploited at higher rates by successful fish than by fish eating below maintenance ration. However, most other terrestrial organisms were not significantly different between both classes of fish and one terrestrial prey class (Hemiptera and Homoptera during the spring) were exploited at a higher rate in fish feeding below maintenance ration. Therefore, while terrestrial organisms exceed aquatic prey in terms of energetic input for brook trout, particular terrestrial organisms may play a dominant role in sustaining fish populations, while others offer comparatively little energetic benefit. This suggests that classifying all terrestrial insects into one group as in other salmonid taxonomic diet studies (Forrester et al. 1994, Bridcut and Giller 1995, Mookerji et al. 2004) may distort the true values of prey importance. One study that did consider terrestrial taxonomic detail is Webster and Hartman (2005), which found that certain terrestrial organisms may score higher in the index of relative importance (IRI) than others. Another study with terrestrial taxonomic detail (Allan 1981) found that non-native brook trout may specifically target Coleoptera in Colorado. Terrestrial Coleoptera were also considered the largest contributor of energy among terrestrial organisms to Alaskan streams (Wiplfi and Gregovich 2002). The findings of the current study concur that particular terrestrial organisms, such as 
Coleoptera and Lepidoptera, may be of disproportionate importance relative to all other prey items.

While brook trout consuming very large organisms (fish, salamanders, and crayfish) were usually found to be feeding above maintenance ration, these prey organisms were detected as significantly important only during the fall (where all fish consuming crayfish were feeding above maintenance ration) and winter (Vertebrata). This likely occurred due to the low rate at which these organisms were encountered. Therefore, while these organisms offer a substantial energy to brook trout capable of capturing them, such captures occur at such a low rate that the statistical method employed in the current study did not consistently detect them as exploited more significantly by fish feeding above maintenance ration during spring and summer. Such a finding may suggest that large organisms play a limited role in sustaining the over all population during some seasons. These findings contrast those of Thorne (2004), which found that vertebrate and crayfish prey dominated brook trout diet by weight. Differences between Thorne (2004) and the current study could have been attributed to a number of factors: energetic values were calculated differently between the studies, the current study sampled a larger number of fish, and Thorne (2004) included two large (30 and $41.7 \mathrm{~km}^{2}$ basin area) mainstem reaches of a stream where brook trout consumed a disproportionate number of fish relative to smaller reaches. Nevertheless, in the current study crayfish and vertebrate prey were detected at higher proportions in fish eating above maintenance ration during fall and winter. Therefore, these large prey organisms may become increasingly important as terrestrial organisms become scarce during colder temperatures. 
Despite taxonomic prey differences between fish eating above and below maintenance ration, other taxa (those not exploited at significantly different rates between groups of fish) did appear to be important prey to the Middle Fork brook trout population. For example, during the winter months, Trichoptera were exploited at very high rates by a majority of the fish. High rates of Trichoptera exploitation during the winter are common in lotic salmonids (Cunjak and Power 1987, Lehane et al. 2001, Sweka and Hartman 2001). While differences in Trichoptera exploitation were not significant between groups of fish, the high energetic contribution by Trichoptera implies that this particular taxa constitutes an important part of the diet during winter. Therefore, prey items that were not found to be exploited at significantly different rates between groups of fish should not be discarded as unimportant. Rather, items found in significantly higher rates in fish feeding above maintenance ration should be considered a component of successful feeding strategy along with a generalist pattern.

Over the course of the study, aquatic insects never emerged as contributing a greater amount of energy in fish feeding above maintenance ration. During spring, specialization on aquatic taxa seemed correlated with daily ration estimates below maintenance, as fish feeding above maintenance ration fed on significantly less Trichoptera (an aquatic insect). While aquatic insects provided a majority of energy during the winter, brook trout grow little and experience low rates of mortality once acclimated to cold water temperatures (Cunjak and Power 1987, Chapter 2). Therefore aquatic insects seem to play a minor role relative to terrestrial insects in shaping and sustaining brook trout populations in this Appalachian watershed. Most dietary studies of lotic salmonids focus taxonomic detail on aquatic insects and group all terrestrials into 
one broad category (Cada et al. 1987, Forrester et al. 1994, Bridcut and Giller 1995, Mookerji et al. 2004). Findings in this study and others (Kawaguchi and Nakano 2001, Sweka 2003) imply that future diet studies of headwater stream salmonids should focus more attention on terrestrial organisms.

\section{Management Implications}

Findings in this study provide details on what constitutes successful feeding for an Appalachian headwater salmonid. Brook trout in the Middle Fork River appear to rely on terrestrial organisms for survival during stressful periods and growth during productive periods. Managers controlling brook trout populations may consider such organisms are disproportionately more important than aquatic insects. Such a concept implies that manipulating riparian zones to control terrestrial insects may have substantial effects on salmonid populations, as demonstrated in Nakano et al. (1999) and Kawaguchi and Nakano (2001). Select organisms in the terrestrial fauna may play a dominant role in sustaining or growing populations. Further, maintaining access to a broad range of prey items, both terrestrial and aquatic, seems to be important in providing necessary feeding conditions for brook trout. 


\section{References}

Allan, J. D. 1981. Determinants of diet of brook trout (Salvelinus fontinalis) in a mountain stream. Canadian Journal of Fisheries and Aquatic Science 38: 184-192.

Allan, R. K. 1951. The Horokiwi stream: a study of a trout population. The New Zealand Marine Department of Fisheries Bulletin 10: 1-231.

Amundsen, P. A., H. M. Gabler, \& F. J. Staldvik. 1996. A new approach to graphical analysis of feeding strategy from stomach contents data- modifications of the Costello (1990) method. Journal of Fish Biology 48: 607-614.

Benke, A. C., A. D. Huryn, L. A. Smock, \& J. B. Wallace . 1999. Length-mass relationships for freshwater macroinvertebrates in North America with particular reference to the southeastern United States. Journal of the North American Benthological Society 18: 308-343.

Borror, D. J., C. A. Triplehorn, \& N. F. Johnson. 1989. An introduction to the study of insects, $6^{\text {th }}$ ed. Saunders College Publishers, Ft. Worth, Texas.

Bowen, S. H. 1996. Quantitative description of the diet. pages 513-529 in B. R. Murphy

and D. W. Willis, eds., Fisheries Techniques, $2^{\text {nd }}$ edition. American Fisheries Society, Bethesda, Maryland.

Bridcut, E. E. \& P. S. Giller. 1995. Diet variability and foraging strategies in brown trout (Salmo trutta): an analysis from subpopulations to individuals. Canadian Journal of Fisheries and Aquatic Science 52: 2543-2552.

Cada, G. F., J. M. Loar \& M. J. Sale. 1987. Evidence of food limitation of rainbow and brown trout in southern Appalachian soft-water streams. Transactions of the American Fisheries Society 116: 692-702.

Chipps, S. R. \& J. E. Garvey. In press. Assessment of food habits and feeding patterns. In M. Brown (eds), Analysis and Interpretation of Freshwater Fisheries Data. American Fisheries Society, Bethesda, MD: xx-yy.

Clayton, J. L., E. S. Dannaway, R. Menendez, H. W. Rauch, J. J. Renton, S. M. Sherlock \& P. E. Zurbuch. 1998. Application of limestone to restore fish communities in acidified streams. American Journal of Fisheries Management 18: 347-360.

Costello, M. J. 1990. Predator feeding strategy and prey importance: a new graphical analysis. Journal of Fish Biology 36: 261-263.

Cummins, K. C. \& J. C. Wuycheck. 1971. Caloric equivalents for investigations in ecological energetics. Mitteilungen der Internationalen Vereinigung fur Theoretische und Angewandte Limnologie 18. 
De Crespin de Billy, V., B. Dumont, T. Lagarrigue, P. Baran \& B. Statzner. 2002. Invertebrate accessibility and vulnerability in the analysis of brown trout (Salmo trutta L.) summer habitat suitability. River Research and Applications 18: 533-553.

Eggers, D. M. 1977. Factors in interpreting data obtained by diel sampling of fish stomachs. Journal of the Fisheries Research Board of Canada 34: 290-294.

Elliot, J. M. 1976. The energetics of feeding, metabolism, and growth of brown trout (Salmo trutta L.) in relation to body weight, water temperature, and ration size. Jounal of Animal Ecology 45: 923-948.

Ensign, W. E., R. J. Strange, \& S. E. Moore. 1990. Summer food limitation reduces brook and rainbow trout biomass in a southern Appalachian stream. Transactions of the American Fisheries Society 119: 894-901.

Forrester, G. E., J. G. Chace, \& W. McCarthy. 1994. Diel and density-related changes in food consumption and prey selection by brook charr in a New Hampshire stream. Environmental Biology of Fishes 39: 301-311.

Hartman, K. J. \& S. B. Brandt. 1995. Estimating energy density of fish. Transactions of the American Fisheries Society 124: 347-355.

Hartman, K. J. \& J. A. Sweka. 2001. Development of a bioenergetics model for Appalachian brook trout. Procedures from the Annual Conference of Southeastern Assosiation of Fisheries and Wildlife Agencies 38-51.

Hayward, R. S. \& F. J. Margraf. 1987. Eutrophication effects on prey size and food available to yellow perch in Lake Erie. Transactions of the American Fisheries Society 116: $210-223$.

Hubert, W. A. \& H. A. Rhodes. 1989. Food selection by brook trout in a subalpine stream. Hydrobiologia 178: 225-231.

Johnston, T. A. \& R. A. Cunjak. 1999. Dry mass-length relationships for benthic insects: a review with new data from Catamaran Brook, New Brunswick, Canada. Freshwater Biology 41: 653-674.

Kawaguchi, C., Y. Taniguchi, \& S. Nakano. 2003. Terrestrial invertebrate inputs determine the local abundance of stream fishes in a forested stream. Ecology 84: 701708 .

Kawaguchi, Y. \& S. Nakano. 2001. Contribution of terrestrial invertebrates to the annual resource budget for salmonids in forest and grassland reaches of a headwater stream. Freshwater Biology 46: 303-316.

Krebs, C. J. 1994. Ecological Methodology, Second ed. Benjamin/Cummings. Menlo Park, CA. 
Lehane, B. M., B. Walsh, P. S. Giller, \& J. O'Halloran. 2001. The influence of smallscale variation in habitat on winter trout distribution and diet in an afforested catchment. Aquatic Ecology 61: 61-71.

Light, R. W., Adler, P. H., \& D. E. Arnold. 1983. Evaluation of gastric lavage for stomach analyses. North American Journal of Fisheries Management 3: 81-85.

McKinney, T. \& D. W. Speas. 2001. Observations of a size-related asymmetries in diet and energy intake of rainbow trout in a regulated river. Environmental Biology of Fishes 61: 435-444.

Merritt, R. W. \& K. W. Cummins. 1996. An introduction to the aquatic insects of North America, $3^{\text {rd }}$ edition. Kendall and Hunt, Dubuque, Iowa.

Mookerji, N., Z. Weng, \& A. Mazumder. 2004. Food partitioning between coexisting Atlantic salmon and brook trout in the Sainte-Marguerite River ecosystem, Quebec. Journal of Fish Biology 64: 680-694.

Nakano, S., H. Miyasaka, \& N. Kuhara. 1999. Terrestrial-aquatic linkages: riparian arthropod inputs alter trophic cascades in a stream food web. Ecology 80: 2435-2441.

Neveu, A. 1999. Feeding strategy of the brown trout (Salmo trutta L.) in running water. In J. L. Bagliniere and G. Maisse (eds), Biology and Ecology of the Brown and Sea Trout. Springer, Chichester, UK: 91-113.

Odenkirk, J. S. \& R. D. Estes. 1991. Food habits of rainbow trout in a Tennessee tailwater. Proceedings from the Annual Conference of Southeastern Assosiation of Fisheries and Wildlife Agencies 45: 451-459.

Platts, W. S. \& R. L. Nelson. 1988. Fluctuations in trout populations and their implications for land-use evaluation. North American Journal of Fisheries Management 8: 333-345.

Sabo, J. L., J. L. Bastow, \& M. E. Power. 2002. Length-mass relationships for adult aquatic and terrestrial invertebrates in a California watershed. Journal of the North American Benthological Society 21: 336-343.

Sample, B. E., R. J. Cooper, R. D. Greer, \& R. C. Whitmore. 1993. Estimation of insect bimass by length and weight. American Midland Naturalist 129: 234-240.

Somerton, D. A. 1991. Detecting diferences in fish diets. Fishery Bulletin 89: 167-169.

Steingrimsson, S. O. \& G. M. Gislason. 2002. Body size, diet and growth of landlocked brown trout, Salmo trutta, in the subarctic River Laxa, North-East Iceland. Environmental Biology of Fishes 63: 417-426. 
Sweka, J. A. \& K. J. Hartman. 2001. Fall and winter brook trout prey selection and daily ration. Procedures from the Annual Conference of Southeastern Assosiation of Fisheries and Wildlife Agencies 55: 8-22.

Sweka, J. A. 2003. Aquatic-terrestrial linkages in Appalachian streams: influence of riparian inputs on stream habitat, brook trout populations, and trophic dynamics. Doctoral Dissertation, West Virginia University, Morgantown. 198 pp.

Sweka, J. A., M. K. Cox \& K. J. Hartman. 2004. Gastric evacuation rates of brook trout. Transactions of the American Fisheries Society 133: 204-210.

Thonney, J. P. \& R. J. Gibson. 1989. Feeding strategies of brook trout, Salvelinus fontinalis, and juvenile Atlantic salmon, Salmo salar, in a Newfoundland river. Canadian Field Naturalist 103: 48-56.

Thorne, D. W. 2004. Spatial and seasonal variation in brook trout diet, growth, and consumption in a complex Appalachian watershed. Masters Thesis, West Virginia University, Morgantown. 93 pp.

Tokeshi, M. 1991. Graphical analysis of predator feeding strategy and prey importance. Freshwater Forum 1: 179-183.

Twomey, H. \& P. S. Giller. 1990. Stomach flushing and individual Panjet tattooing of salmonids: an evaluation of the long-term effects on two wild populations. Aquaculture and Fisheries Management 21: 137-142.

Vannote, R. L., G. W. Minshall, K. W. Cummins, J. R. Sedell, \& C. E. Cushing. 1980. The river continuum concept. Canadian Journal of Fisheries and Aquatic Science 37: $130-137$.

Webster, J. J. \& K. J. Hartman. 2005. The role of terrestrial invertebrates in allopatric brook trout headwater streams in the central Appalachian mountains. Journal of Freshwater Ecology 20: 101-107.

Wipfli, M. S. 1997. Terrestrial invertebrates as salmonid prey and nitrogen sources in streams: contrasting old-growth and young-growth riparian forests in southeastern Alaska, USA. Canadian Journal of Fisheries and Aquatic Science 54: 1259-1269.

WVDNR (West Virginia Division of Natural Resources). Middle Fork River: Limestrone treatment of acid mine drainage. 2001. Elkins, West Virginia . 


\section{Tables}

Table 1. Dates of fish sampling in the Middle Fork watershed designated by month.

\begin{tabular}{ccc}
\hline Sampling Period & Start date & End date \\
\hline March 2004 & $3 / 13$ & $3 / 20$ \\
May 2004 & $5 / 10$ & $5 / 12$ \\
June 2004 & $6 / 13$ & $6 / 16$ \\
July 2004 & $7 / 16$ & $7 / 19$ \\
August 2004 & $8 / 16$ & $8 / 18$ \\
September 2004 & $9 / 24$ & $9 / 26$ \\
December 2004 & $12 / 2$ & $12 / 5$ \\
March 2005 & $3 / 12$ & $3 / 18$ \\
May 2005 & $5 / 9$ & $5 / 11$ \\
June 2005 & $6 / 9$ & $6 / 11$ \\
July 2005 & $7 / 12$ & $7 / 13$ \\
\hline
\end{tabular}


Table 2. Designations of sampling periods into seasonal categories for analyses of consumption estimates. Classifications into season were based on feeding intensity and temperature.

\begin{tabular}{lccc}
\hline Season & $\begin{array}{c}\text { Sampling } \\
\text { Periods }\end{array}$ & $\begin{array}{c}\text { Mean } \\
\text { Temperature }\left({ }^{\circ} \mathrm{C}\right)\end{array}$ & $\begin{array}{c}\text { Mean } \\
\text { Consumption } \\
\left(\mathrm{J} \mathrm{g} \mathrm{g}^{-1} \mathrm{~d}^{-1}\right)\end{array}$ \\
\hline Spring & May 2004 & 11.04 & \\
& June 2004 & 15.88 & 57.19 \\
& May 2005 & 12.49 & 49.73 \\
& June 2005 & 15.40 & 59.79 \\
Summer & & & 38.66 \\
& July 2004 & 16.20 & 16.91 \\
& August 2004 & 18.02 & 18.62 \\
Fall & July 2005 & 16.87 & 22.95 \\
Winter & & & \\
& September 2004 & 14.37 & 20.99 \\
& & & \\
& March 2004 & 5.33 & 6.99 \\
& December 2004 & 5.19 & 11.51 \\
& March 2005 & 2.61 & 7.92 \\
\hline
\end{tabular}


Table 3. Mean and standard error (SE) of the reciprocal Shannon's diversity index (1/D) and the number of families observed per stomach for each month. Means with different letters within a column are significantly different following a square-root transformation.

\begin{tabular}{lccccc}
\hline & \multicolumn{2}{c}{$1 / \mathrm{D}$} & & \multicolumn{2}{c}{ Families per stomach } \\
\cline { 2 - 3 } \cline { 6 - 7 } & Mean & SE & & Mean & SE \\
\hline March 04 & $6.26^{\mathrm{A}, \mathrm{B}}$ & 1.28 & & $5.19^{\mathrm{A}}$ & 0.39 \\
May 04 & $8.43^{\mathrm{C}}$ & 0.90 & & $9.44^{\mathrm{B}}$ & 0.50 \\
June 04 & $17.63^{\mathrm{D}}$ & 1.93 & & $9.86^{\mathrm{B}}$ & 0.62 \\
July 04 & $9.37^{\mathrm{C}}$ & 1.36 & & $4.65^{\mathrm{A}, \mathrm{C}, \mathrm{D}}$ & 0.31 \\
August 04 & $5.75^{\mathrm{A}, \mathrm{B}}$ & 0.80 & & $4.28^{\mathrm{C}, \mathrm{D}}$ & 0.35 \\
September 04 & $5.52^{\mathrm{A}, \mathrm{B}}$ & 0.60 & & $5.60^{\mathrm{A}}$ & 0.35 \\
December 04 & $4.17^{\mathrm{B}}$ & 0.55 & & $3.85^{\mathrm{D}}$ & 0.23 \\
March 05 & $3.90^{\mathrm{B}}$ & 0.39 & & $3.76^{\mathrm{D}}$ & 0.21 \\
May 05 & $11.84^{\mathrm{E}}$ & 1.30 & & $14.73^{\mathrm{E}}$ & 0.57 \\
June 05 & $12.07^{\mathrm{E}}$ & 1.34 & & $9.52^{\mathrm{B}}$ & 0.50 \\
July 05 & $8.15^{\mathrm{A}, \mathrm{C}}$ & 0.95 & & $5.69^{\mathrm{C}}$ & 0.39 \\
\hline
\end{tabular}


Table 4. Mean and standard error (SE) of prey consumption $\left(\mathrm{J} \mathrm{g}^{-1} \mathrm{~d}^{-1}\right)$ by source of prey for each month. Results of t-tests between mean aquatic and terrestrial consumption are provided.

\begin{tabular}{|c|c|c|c|c|c|c|c|}
\hline \multirow[b]{2}{*}{ Month } & \multicolumn{2}{|c|}{ Aquatic } & \multicolumn{2}{|c|}{ Terrestrial } & \multirow[b]{2}{*}{$\mathrm{df}$} & \multirow[b]{2}{*}{$\mathrm{t}$} & \multirow[b]{2}{*}{ p-value } \\
\hline & Mean & SE & Mean & SE & & & \\
\hline March04 & 7.09 & 0.85 & 0.27 & 0.06 & 94 & 4.36 & $<0.0001$ \\
\hline May04 & 9.72 & 1.42 & 51.10 & 8.00 & 165 & -5.24 & $<0.0001$ \\
\hline June04 & 11.46 & 1.63 & 40.59 & 4.64 & 161 & -5.95 & $<0.0001$ \\
\hline July04 & 4.34 & 0.92 & 16.51 & 3.07 & 139 & -3.73 & 0.0003 \\
\hline August04 & 7.06 & 1.96 & 20.07 & 5.68 & 110 & -2.10 & 0.0377 \\
\hline September04 & 4.58 & 1.34 & 19.23 & 2.70 & 140 & -4.64 & $<0.0001$ \\
\hline December04 & 11.55 & 1.18 & 2.06 & 0.83 & 92 & 4.21 & $<0.0001$ \\
\hline March05 & 8.14 & 1.13 & 0.28 & 0.14 & 99 & 2.88 & 0.0048 \\
\hline May05 & 19.29 & 1.73 & 40.92 & 4.19 & 176 & -4.74 & $<0.0001$ \\
\hline June05 & 7.74 & 1.47 & 31.97 & 3.85 & 172 & -5.84 & $<0.0001$ \\
\hline July05 & 6.41 & 1.28 & 20.68 & 4.48 & 151 & -3.08 & 0.0024 \\
\hline
\end{tabular}


Table 5. Number of fish consuming energy above and below maintenance ration by count and percentage during each month.

\begin{tabular}{|c|c|c|c|c|c|c|}
\hline \multirow[b]{2}{*}{ Season } & \multirow[b]{2}{*}{ Month } & \multirow[b]{2}{*}{$\mathrm{n}$} & \multicolumn{2}{|c|}{$\begin{array}{c}\text { Above } \\
\text { Maintenance } \\
\text { Ration }\end{array}$} & \multicolumn{2}{|c|}{$\begin{array}{c}\text { Below } \\
\text { Maintenance } \\
\text { ration }\end{array}$} \\
\hline & & & $\mathrm{n}$ & $\%$ & $\mathrm{n}$ & $\%$ \\
\hline \multicolumn{7}{|l|}{ Spring } \\
\hline & May 2004 & 87 & 67 & 77.01 & 20 & 22.99 \\
\hline & June 2004 & 84 & 67 & 79.76 & 17 & 20.24 \\
\hline & May 2005 & 90 & 87 & 96.67 & 3 & 3.33 \\
\hline & June 2005 & 90 & 62 & 68.89 & 28 & 31.11 \\
\hline \multicolumn{7}{|c|}{ Summer } \\
\hline & July 2004 & 81 & 28 & 34.57 & 53 & 65.43 \\
\hline & August 2004 & 73 & 26 & 35.82 & 47 & 64.18 \\
\hline & July 2005 & 86 & 33 & 38.37 & 53 & 61.63 \\
\hline \multicolumn{7}{|l|}{ Fall } \\
\hline & September 2004 & 81 & 37 & 45.68 & 44 & 54.32 \\
\hline \multicolumn{7}{|l|}{ Winter } \\
\hline & March 2004 & 74 & 14 & 18.92 & 60 & 81.08 \\
\hline & December 2004 & 73 & 33 & 45.21 & 40 & 54.79 \\
\hline & March 2005 & 86 & 22 & 25.58 & 64 & 74.42 \\
\hline
\end{tabular}


Table 6. Mean and standard error (SE) for number of prey families observed per fish for fish eating above and below maintenance ration during each season. Results of t-tests between means within a season are provided.

\begin{tabular}{|c|c|c|c|c|c|c|c|}
\hline \multirow[b]{2}{*}{ Season } & \multicolumn{2}{|c|}{ Above } & \multicolumn{2}{|c|}{ Below } & \multirow[b]{2}{*}{$\mathrm{df}$} & \multirow[b]{2}{*}{$\mathrm{T}$} & \multirow[b]{2}{*}{$\mathrm{p}$} \\
\hline & Mean & $\mathrm{SE}$ & Mean & $\mathrm{SE}$ & & & \\
\hline Spring & 12.01 & 0.33 & 6.41 & 0.40 & 349 & 8.03 & $<0.0001$ \\
\hline Summer & 6.55 & 0.39 & 3.99 & 0.20 & 232 & 6.50 & $<0.0001$ \\
\hline Winter & 5.30 & 0.38 & 3.79 & 0.17 & 231 & 4.23 & $<0.0001$ \\
\hline Fall & 6.41 & 0.58 & 4.93 & 0.41 & 79 & 2.14 & 0.0358 \\
\hline
\end{tabular}


Table 7. Mean and standard error (SE) of the reciprocal Shannon's diversity index (1/D) for fish eating above and below maintenance ration during each season. Results of t-tests between means within a season are provided.

\begin{tabular}{|c|c|c|c|c|c|c|c|}
\hline \multirow[b]{2}{*}{ Season } & \multicolumn{2}{|c|}{ Above } & \multicolumn{2}{|c|}{ Below } & \multirow[b]{2}{*}{$\mathrm{df}$} & \multirow[b]{2}{*}{$\mathrm{T}$} & \multirow[b]{2}{*}{$\mathrm{p}$} \\
\hline & Mean & SE & Mean & SE & & & \\
\hline Spring & 12.52 & 0.78 & 12.09 & 1.82 & 349 & 0.23 & 0.8155 \\
\hline Summer & 9.81 & 1.19 & 6.79 & 0.72 & 232 & 2.32 & 0.0215 \\
\hline Winter & 4.38 & 0.77 & 4.88 & 0.58 & 231 & -0.49 & 0.6241 \\
\hline Fall & 5.56 & 0.79 & 5.49 & 0.89 & 79 & 0.06 & 0.9546 \\
\hline
\end{tabular}


Table 8. Results of MANOVA tests of differences in prey proportion (by energy) between fish eating above and below maintenance ration.

\begin{tabular}{lcccc}
\hline Season & Categorical df & Den df & Hotelling's T & p-value \\
\hline Spring & 10 & 340 & 0.4104 & $<0.0001$ \\
Summer & 10 & 223 & 0.2480 & $<0.0001$ \\
Fall & 10 & 70 & 0.3609 & 0.0117 \\
Winter & 10 & 222 & 0.1416 & 0.0009 \\
\hline
\end{tabular}


Table 9. Mean proportion of prey taxa in fish feeding above and below maintenance ration. Results of t-tests between mean proportions per taxa are provided. P-values with an asterisk denote a significant difference at the $\alpha=0.005$ level.

\begin{tabular}{|c|c|c|c|c|c|c|c|c|c|}
\hline \multirow[b]{2}{*}{ Season } & \multirow[b]{2}{*}{ Order } & \multirow{2}{*}{$\begin{array}{c}\text { Origin } \\
(\mathrm{A} / \mathrm{T})\end{array}$} & \multicolumn{2}{|c|}{ Above } & \multicolumn{2}{|c|}{ Below } & \multirow[b]{2}{*}{ df } & \multirow[b]{2}{*}{$\mathrm{T}$} & \multirow[b]{2}{*}{$\mathrm{p}$} \\
\hline & & & Mean & SE & Mean & SE & & & \\
\hline \multicolumn{10}{|l|}{ Spring } \\
\hline & Diptera & $\mathrm{A}$ & 0.1197 & 0.0112 & 0.1392 & 0.0247 & 349 & -0.30 & 0.7580 \\
\hline & Trichoptera & A & 0.0192 & 0.0023 & 0.1249 & 0.0287 & 349 & -6.07 & $<0.0001 *$ \\
\hline & Ephemeroptera & $\mathrm{A}$ & 0.0327 & 0.0048 & 0.0543 & 0.0129 & 349 & -1.44 & 0.1452 \\
\hline & Hemiptera/Homoptera & $\mathrm{T}$ & 0.0059 & 0.0007 & 0.0393 & 0.0133 & 349 & -3.98 & $<0.0001 *$ \\
\hline & Coleoptera & $\mathrm{T}$ & 0.4327 & 0.0197 & 0.1816 & 0.0335 & 349 & 6.53 & $<0.0001 *$ \\
\hline & Diptera & $\mathrm{T}$ & 0.0970 & 0.0088 & 0.1306 & 0.0283 & 349 & -0.12 & 0.8968 \\
\hline & Hymenoptera & $\mathrm{T}$ & 0.0523 & 0.0072 & 0.0617 & 0.0194 & 349 & 0.16 & 0.8660 \\
\hline & Plecoptera & A & 0.0594 & 0.0083 & 0.0913 & 0.0202 & 349 & -1.58 & 0.1108 \\
\hline & Other & A & 0.0573 & 0.0098 & 0.1093 & 0.0268 & 349 & -1.79 & 0.0178 \\
\hline & Other & $\mathrm{T}$ & 0.1238 & 0.0141 & 0.0678 & 0.0217 & 349 & 2.38 & 0.0188 \\
\hline \multicolumn{10}{|l|}{ Summer } \\
\hline & Coleoptera & $\mathrm{T}$ & 0.2122 & 0.0332 & 0.1039 & 0.0186 & 232 & 3.45 & $0.0006^{*}$ \\
\hline & Diptera & $\mathrm{A}$ & 0.0517 & 0.0158 & 0.0963 & 0.0174 & 232 & -2.08 & 0.0382 \\
\hline & Diptera & $\mathrm{T}$ & 0.1246 & 0.0255 & 0.1718 & 0.0241 & 232 & -1.10 & 0.2668 \\
\hline & Hymenoptera & $\mathrm{T}$ & 0.0802 & 0.0202 & 0.0709 & 0.0165 & 232 & 0.87 & 0.3944 \\
\hline & Trichoptera & A & 0.0100 & 0.0041 & 0.0548 & 0.0143 & 232 & -2.16 & 0.0266 \\
\hline & Lepidoptera & $\mathrm{T}$ & 0.1923 & 0.0332 & 0.1033 & 0.0200 & 232 & 3.24 & $0.0020^{*}$ \\
\hline & Decapoda & A & 0.1069 & 0.0300 & 0.0554 & 0.0160 & 232 & 1.70 & 0.0888 \\
\hline & Vertebrata & A & 0.0436 & 0.0193 & 0.0358 & 0.0140 & 232 & 0.44 & 0.6538 \\
\hline & Other & A & 0.0635 & 0.0156 & 0.1581 & 0.0240 & 232 & -2.26 & 0.0224 \\
\hline & Other & $\mathrm{T}$ & 0.1151 & 0.0256 & 0.1499 & 0.0218 & 232 & -0.84 & 0.4032 \\
\hline \multicolumn{10}{|l|}{ Fall } \\
\hline & Hemiptera/Homoptera & $\mathrm{T}$ & 0.0662 & 0.0280 & 0.1697 & 0.0360 & 79 & -2.51 & 0.0136 \\
\hline & Hymenoptera & $\mathrm{T}$ & 0.0474 & 0.0170 & 0.1490 & 0.0347 & 79 & -2.51 & 0.0122 \\
\hline & Lepidoptera & $\mathrm{T}$ & 0.5496 & 0.0580 & 0.2833 & 0.0509 & 79 & 3.55 & $0.0006^{*}$ \\
\hline & Diptera & A & 0.0186 & 0.0068 & 0.0290 & 0.0076 & 79 & -0.81 & 0.4196 \\
\hline & Orthoptera & $\mathrm{T}$ & 0.0514 & 0.0245 & 0.0432 & 0.0276 & 79 & 0.50 & 0.6260 \\
\hline & Vertebrata & A & 0.0448 & 0.0319 & 0.0326 & 0.0237 & 79 & 0.17 & 0.8623 \\
\hline & Decapoda & A & 0.0506 & 0.0339 & 0.0000 & 0.0000 & 79 & - & - \\
\hline & Coleoptera & $\mathrm{T}$ & 0.0560 & 0.0279 & 0.0396 & 0.0205 & 79 & 0.74 & 0.4602 \\
\hline & Other & $\mathrm{A}$ & 0.0409 & 0.0148 & 0.1065 & 0.0367 & 79 & -1.33 & 0.1916 \\
\hline & Other & $\mathrm{T}$ & 0.0747 & 0.0308 & 0.1470 & 0.0352 & 79 & -1.75 & 0.0852 \\
\hline \multicolumn{10}{|l|}{ Winter } \\
\hline & Trichoptera & A & 0.5300 & 0.0400 & 0.6335 & 0.0270 & 231 & -1.84 & 0.0678 \\
\hline & Ephemeroptera & A & 0.0931 & 0.0216 & 0.1373 & 0.0189 & 231 & -1.05 & 0.2906 \\
\hline & Plecoptera & A & 0.1581 & 0.0354 & 0.0982 & 0.0162 & 231 & 1.68 & 0.0962 \\
\hline & Diptera & A & 0.0570 & 0.0142 & 0.0547 & 0.0129 & 231 & 0.85 & 0.3718 \\
\hline & Vertebrata & $\mathrm{A}$ & 0.0544 & 0.0239 & 0.0064 & 0.0049 & 231 & 2.95 & $0.0032 *$ \\
\hline & Coleoptera & A & 0.0517 & 0.0160 & 0.0276 & 0.0094 & 231 & 1.94 & 0.0476 \\
\hline & Decapoda & A & 0.0099 & 0.0077 & 0.0101 & 0.0051 & 231 & 0.09 & 0.9352 \\
\hline & Non-insect Arthropoda & $\mathrm{T}$ & 0.0108 & 0.0072 & 0.0111 & 0.0056 & 231 & 0.46 & 0.6238 \\
\hline & Other & $\mathrm{A}$ & 0.0194 & 0.0133 & 0.0081 & 0.0055 & 231 & 1.35 & 0.1687 \\
\hline & Other & $\mathrm{T}$ & 0.0156 & 0.0073 & 0.0130 & 0.0037 & 231 & 0.85 & 0.8614 \\
\hline
\end{tabular}




\section{Figures}

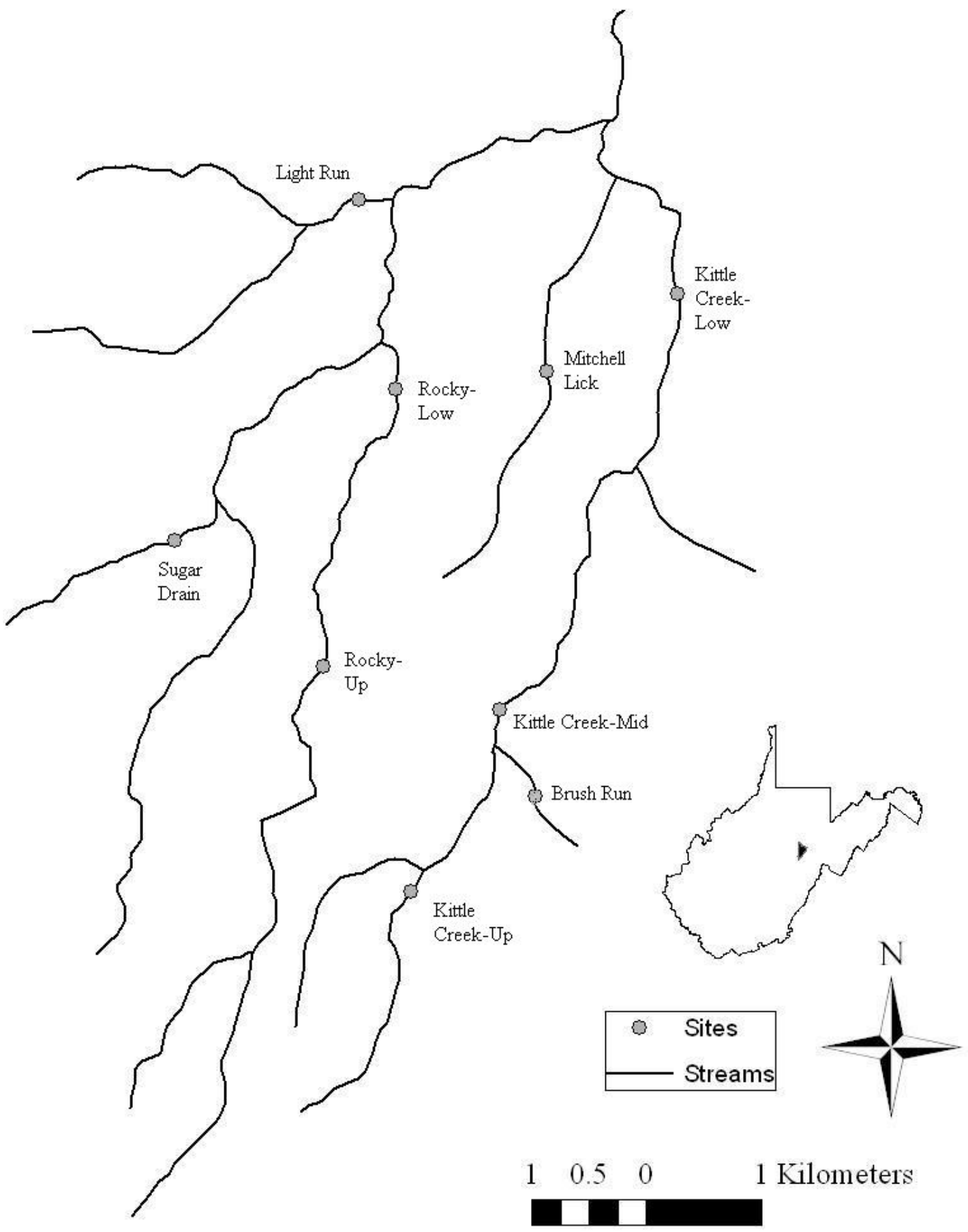

Figure 1. The upper Middle Fork watershed and all sites described for this study. 


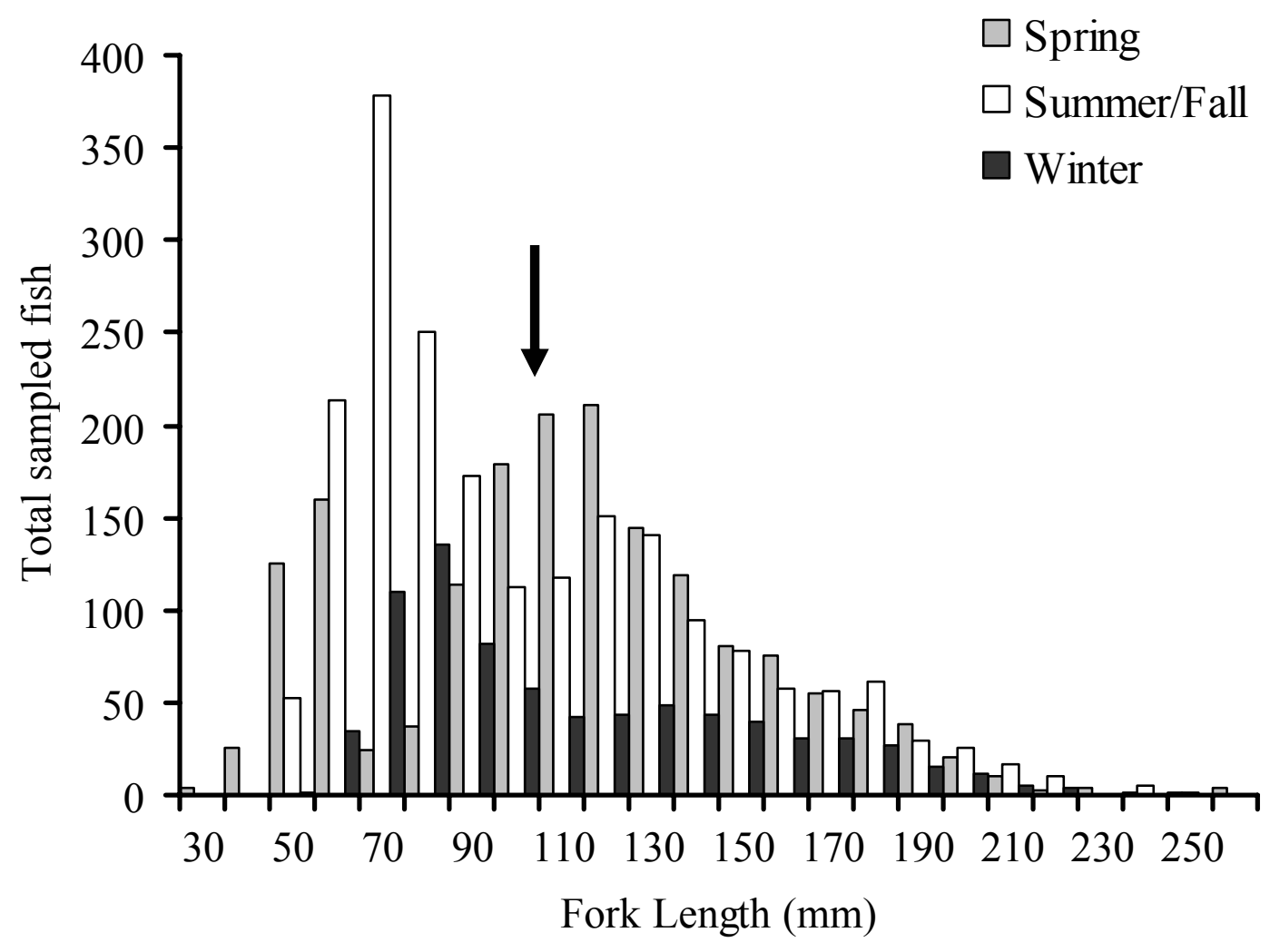

Figure 2. Length-frequency histogram of all fish captured in the Middle Fork watershed by season. The arrow indicates the size considered large enough to sample gut contents. 

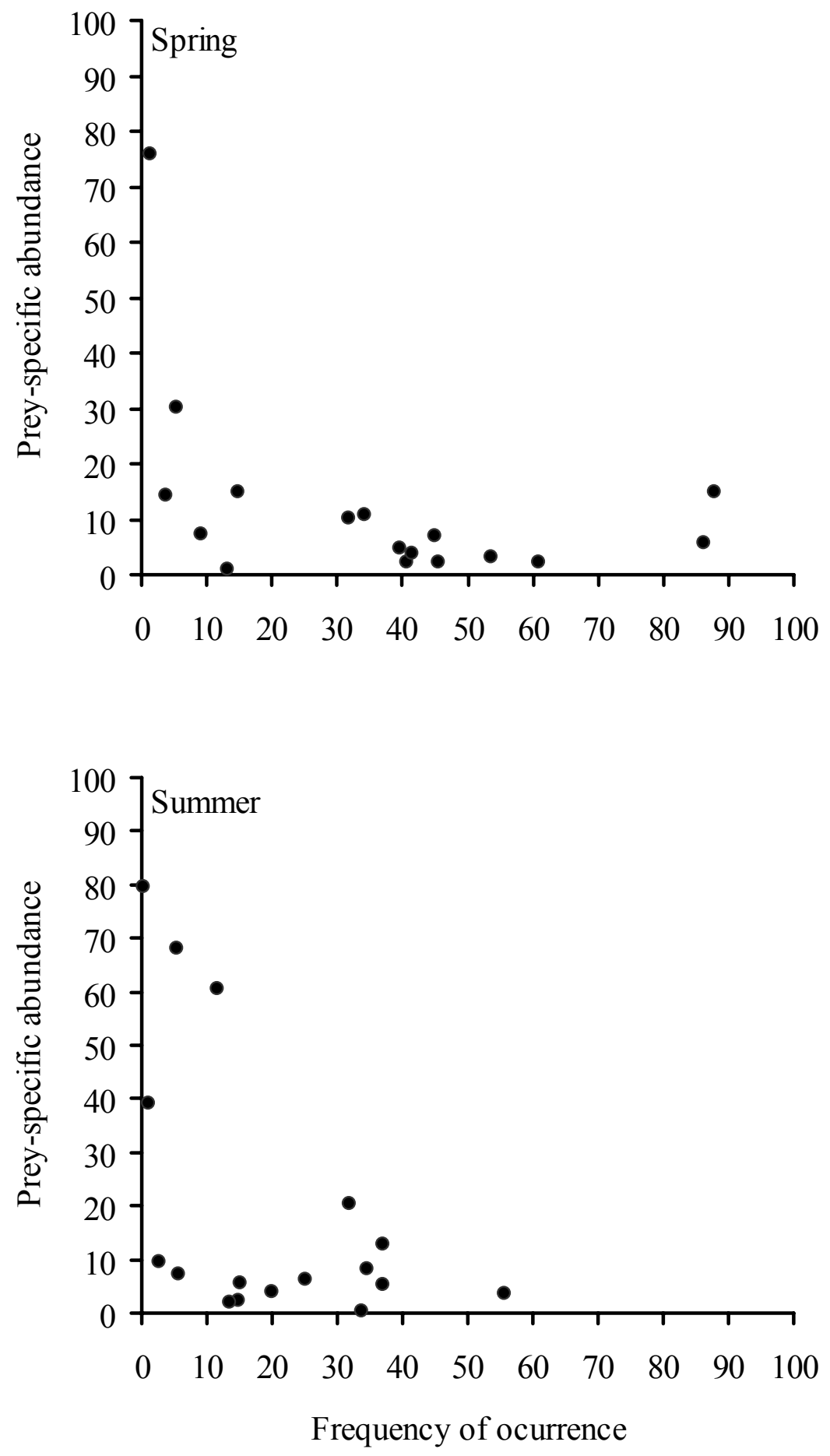

Figure 3. Feeding strategy of the Middle Fork brook trout population during spring and summer. Each point represents a prey type based on taxonomic order and origin (terrestrial or aquatic) for brook trout in the Middle Fork Watershed, West Virginia. 

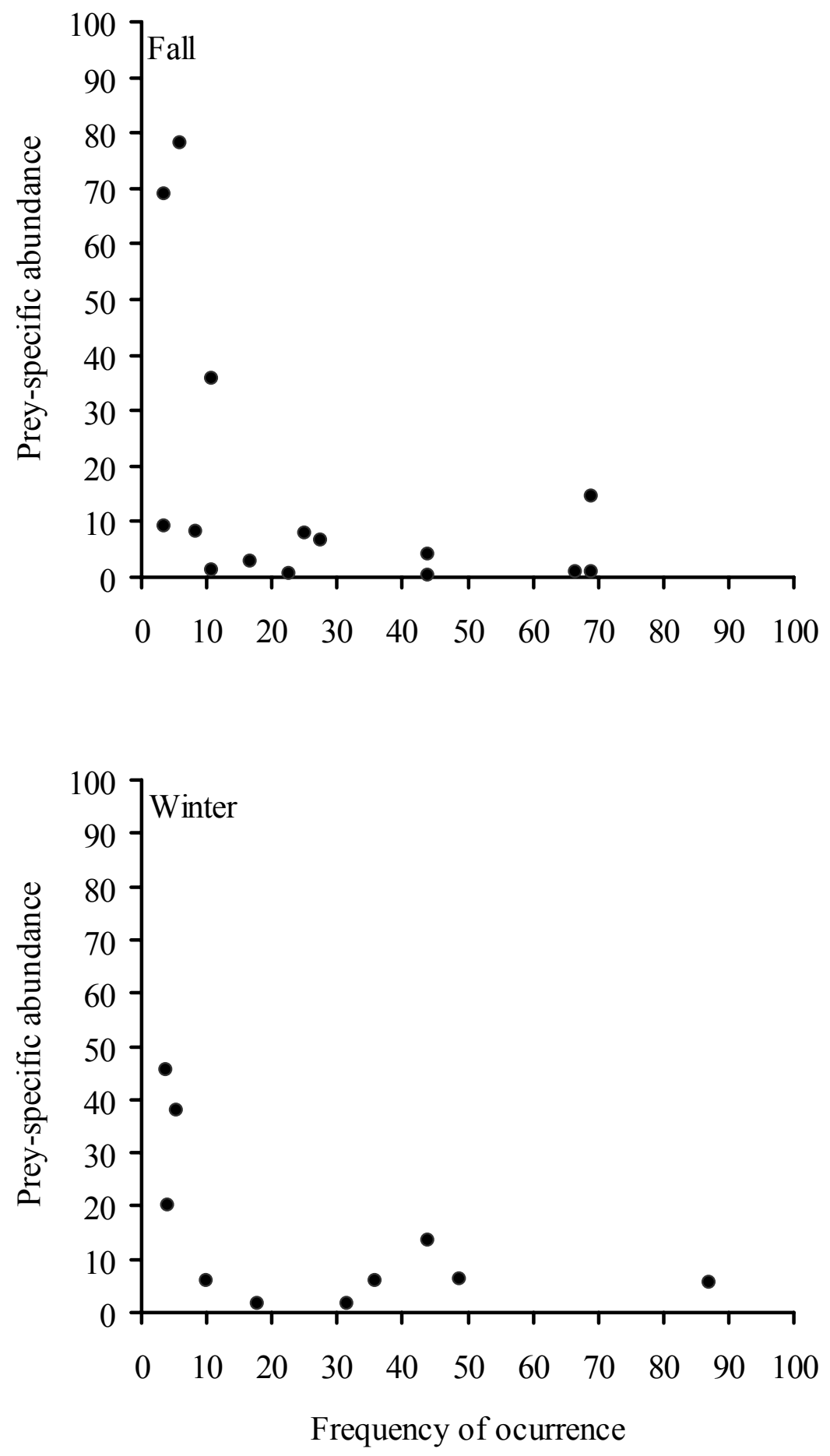

Figure 4. Feeding strategy of the Middle Fork brook trout population during fall and winter. Each point represents a prey type based on taxonomic order and origin (terrestrial or aquatic) for brook trout in the Middle Fork Watershed, West Virginia. 

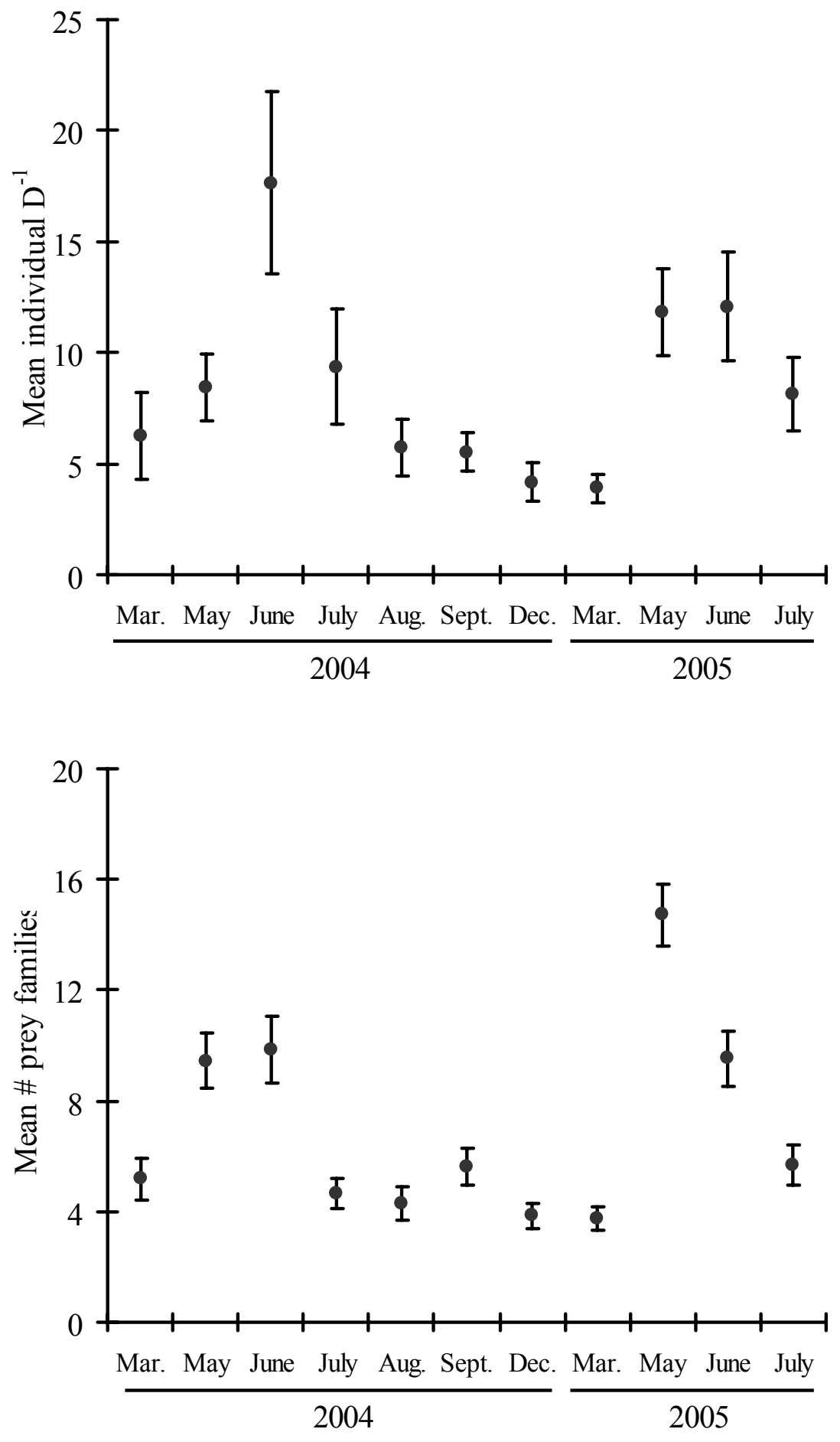

Figure 5. Mean $( \pm 95 \% \mathrm{CI})$ familial prey diversity $\left(\mathrm{D}^{-1}\right)$ and number of observed families in brook trout stomachs across all months. 


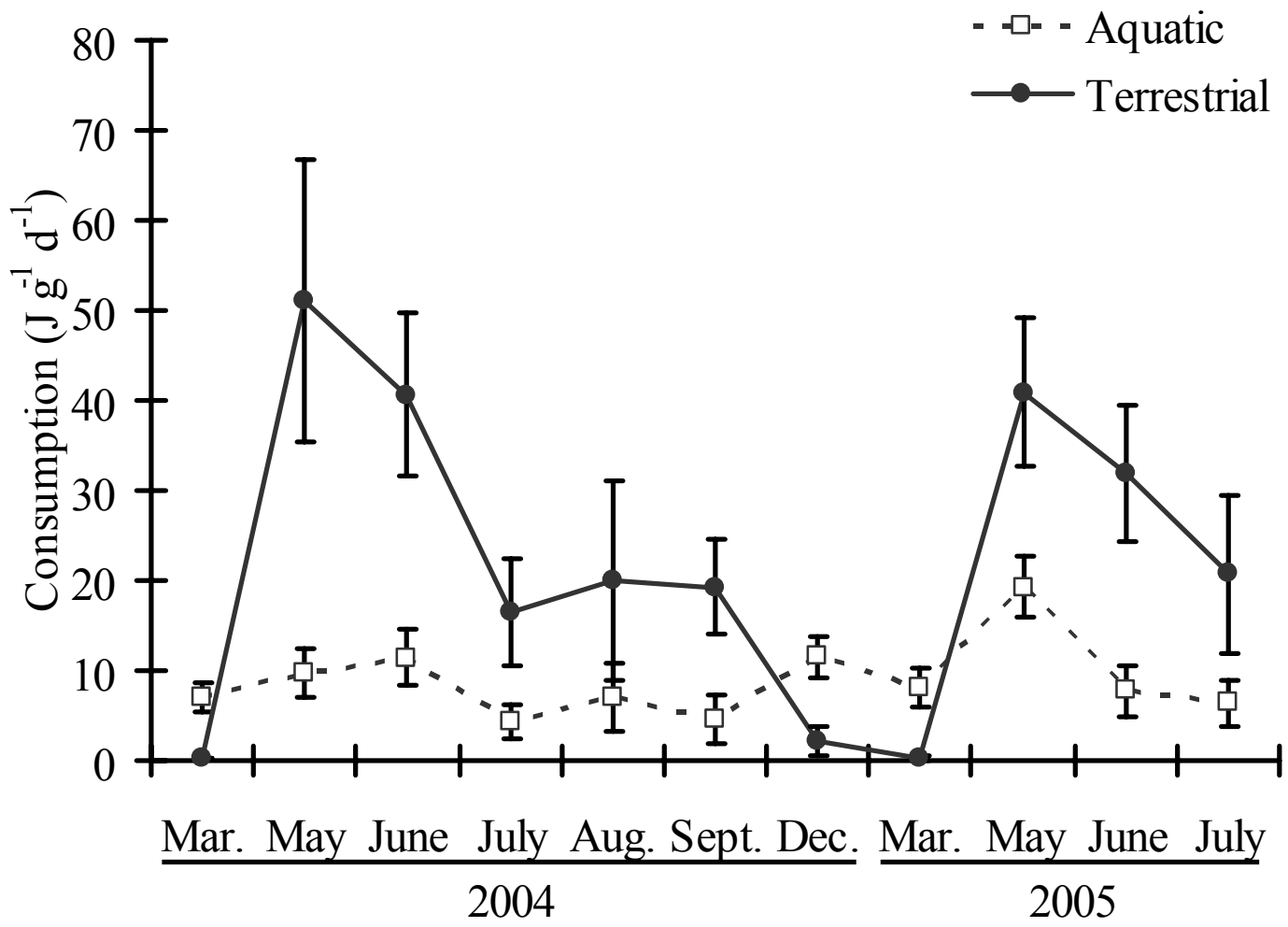

Figure 6. Mean consumption $( \pm 95 \% \mathrm{CI})$ by source of prey during each month. 
Appendix A (Stomach contents): Summary of all food items recorded in brook trout diets by count and energy.

\begin{tabular}{|c|c|c|c|c|c|c|c|}
\hline Season & Order & Family & Stage & $\begin{array}{l}\text { Combined } \\
\text { energy }(J)\end{array}$ & $\begin{array}{c}\% \text { of total } \\
\text { energy }\end{array}$ & Count & $\begin{array}{c}\% \text { of total } \\
\text { count } \\
\end{array}$ \\
\hline \multirow[t]{49}{*}{ Summer/Fall } & Aranae & spp. & adult & 11893.02 & 1.7787 & 65 & 1.918 \\
\hline & Blattaria & Cryptocercidae & adult & 5561.81 & 0.8318 & 1 & 0.030 \\
\hline & Caudata & Plethodontidae & adult & 11158.46 & 1.6688 & 9 & 0.266 \\
\hline & Coleoptera & Bruchidae & adult & 3.92 & 0.0006 & 1 & 0.030 \\
\hline & & Buprestridae & adult & 2176.86 & 0.3256 & 3 & 0.089 \\
\hline & & Cantharidae & adult & 1401.58 & 0.2096 & 23 & 0.679 \\
\hline & & Carabidae & adult & 18516.36 & 2.7693 & 25 & 0.738 \\
\hline & & Cerambycidae & adult & 4629.00 & 0.6923 & 8 & 0.236 \\
\hline & & Chrysomelidae & adult & 5804.58 & 0.8681 & 24 & 0.708 \\
\hline & & Coccinellidae & adult & 2898.14 & 0.4334 & 7 & 0.207 \\
\hline & & Curculionidae & adult & 977.66 & 0.1462 & 26 & 0.767 \\
\hline & & Dytiscidae & adult & 631.84 & 0.0945 & 6 & 0.177 \\
\hline & & Dytiscidae & larvae & 935.87 & 0.1400 & 5 & 0.148 \\
\hline & & Elateridae & adult & 6153.35 & 0.9203 & 18 & 0.531 \\
\hline & & Elmidae & larvae & 52.21 & 0.0078 & 4 & 0.118 \\
\hline & & Gyrinidae & adult & 7125.16 & 1.0656 & 5 & 0.148 \\
\hline & & Gyrinidae & larvae & 1302.46 & 0.1948 & 3 & 0.089 \\
\hline & & Hydrophilidae & adult & 253.79 & 0.0380 & 1 & 0.030 \\
\hline & & Lycidae & adult & 807.00 & 0.1207 & 4 & 0.118 \\
\hline & & Mordellidae & adult & 26.89 & 0.0040 & 1 & 0.030 \\
\hline & & Mycetophagidae & adult & 10.37 & 0.0016 & 2 & 0.059 \\
\hline & & Noteridae & adult & 5.09 & 0.0008 & 1 & 0.030 \\
\hline & & Oedemeridae & adult & 166.19 & 0.0249 & 1 & 0.030 \\
\hline & & Pedilidae & adult & 96.04 & 0.0144 & 1 & 0.030 \\
\hline & & Pselaphidae & adult & 3.40 & 0.0005 & 1 & 0.030 \\
\hline & & Psephenidae & adult & 8.02 & 0.0012 & 1 & 0.030 \\
\hline & & Scarabaeidae & adult & 19990.05 & 2.9897 & 17 & 0.502 \\
\hline & & Scolytidae & adult & 69.95 & 0.0105 & 8 & 0.236 \\
\hline & & spp. & adult & 4230.30 & 0.6327 & 41 & 1.210 \\
\hline & & Staphylinidae & adult & 595.85 & 0.0891 & 17 & 0.502 \\
\hline & Collembola & Isotomidae & adult & 66.67 & 0.0100 & 3 & 0.089 \\
\hline & & Sminthuridae & adult & 3.24 & 0.0005 & 3 & 0.089 \\
\hline & Decapoda & Cambaridae & adult & 59567.49 & 8.9089 & 35 & 1.033 \\
\hline & Diplopoda & spp. & adult & 8260.38 & 1.2354 & 13 & 0.384 \\
\hline & Diptera & Anisopodidae & adult & 63.15 & 0.0094 & 1 & 0.030 \\
\hline & & Asilidae & adult & 22490.50 & 3.3637 & 20 & 0.590 \\
\hline & & Bombyliidae & adult & 908.23 & 0.1358 & 6 & 0.177 \\
\hline & & Ceratopogonidae & adult & 341.99 & 0.0511 & 10 & 0.295 \\
\hline & & Chironomidae & adult & 9.54 & 0.0014 & 10 & 0.295 \\
\hline & & Chironomidae & larvae & 29.55 & 0.0044 & 18 & 0.531 \\
\hline & & Dolichopodidae & adult & 818.41 & 0.1224 & 30 & 0.885 \\
\hline & & Drosophilidae & adult & 475.72 & 0.0711 & 23 & 0.679 \\
\hline & & Empididae & adult & 8743.60 & 1.3077 & 276 & 8.144 \\
\hline & & Empididae & larvae & 6.02 & 0.0009 & 1 & 0.030 \\
\hline & & Muscidae & adult & 566.65 & 0.0847 & 12 & 0.354 \\
\hline & & Mycetophilidae & adult & 178.21 & 0.0267 & 9 & 0.266 \\
\hline & & Ottidae & adult & 47.22 & 0.0071 & 1 & 0.030 \\
\hline & & Phoridae & adult & 58.06 & 0.0087 & 8 & 0.236 \\
\hline & & Pipunculidae & adult & 82.71 & 0.0124 & 3 & 0.089 \\
\hline
\end{tabular}


Appendix A continued

\begin{tabular}{|c|c|c|c|c|c|c|c|}
\hline Season & Order & Family & Stage & $\begin{array}{l}\text { Combined } \\
\text { energy }(J)\end{array}$ & $\begin{array}{c}\% \text { of total } \\
\text { energy }\end{array}$ & Count & $\begin{array}{c}\% \text { of total } \\
\text { count }\end{array}$ \\
\hline \multirow[t]{49}{*}{ Summer/Fall } & \multirow[t]{14}{*}{ Diptera } & Rhagionidae & adult & 125.99 & 0.0188 & 1 & 0.030 \\
\hline & & Scatopsidae & adult & 25.31 & 0.0038 & 1 & 0.030 \\
\hline & & Sciaridae & adult & 88.09 & 0.0132 & 7 & 0.207 \\
\hline & & Sciomyzidae & adult & 22.78 & 0.0034 & 1 & 0.030 \\
\hline & & Simuliidae & adult & 9.14 & 0.0014 & 12 & 0.354 \\
\hline & & Simuliidae & larvae & 4.79 & 0.0007 & 1 & 0.030 \\
\hline & & spp. & adult & 16226.21 & 2.4268 & 190 & 5.606 \\
\hline & & spp. & larvae & 2947.43 & 0.4408 & 560 & 16.524 \\
\hline & & spp. & pupae & 80.68 & 0.0121 & 31 & 0.915 \\
\hline & & Syrphidae & adult & 180.35 & 0.0270 & 2 & 0.059 \\
\hline & & Tachninidae & adult & 380.36 & 0.0569 & 3 & 0.089 \\
\hline & & Tephritidae & adult & 114.89 & 0.0172 & 3 & 0.089 \\
\hline & & Tipulidae & adult & 7101.84 & 1.0621 & 20 & 0.590 \\
\hline & & Tipulidae & larvae & 754.28 & 0.1128 & 4 & 0.118 \\
\hline & \multirow[t]{9}{*}{ Ephemeroptera } & Ameletidae & larvae & 198.34 & 0.0297 & 4 & 0.118 \\
\hline & & Baetidae & adult & 124.40 & 0.0186 & 10 & 0.295 \\
\hline & & Baetidae & larvae & 78.10 & 0.0117 & 9 & 0.266 \\
\hline & & Ephemerellidae & larvae & 522.83 & 0.0782 & 11 & 0.325 \\
\hline & & Heptageniidae & adult & 1236.23 & 0.1849 & 4 & 0.118 \\
\hline & & Heptageniidae & larvae & 2780.82 & 0.4159 & 18 & 0.531 \\
\hline & & Potamanthidae & larvae & 40.78 & 0.0061 & 3 & 0.089 \\
\hline & & spp. & adult & 806.57 & 0.1206 & 10 & 0.295 \\
\hline & & spp. & larvae & 1038.58 & 0.1553 & 14 & 0.413 \\
\hline & \multirow[t]{16}{*}{ Hemiptera } & Cydnidae & adult & 156.28 & 0.0234 & 49 & 1.446 \\
\hline & & Gerridae & adult & 3160.88 & 0.4727 & 25 & 0.738 \\
\hline & & Hydrometridae & adult & 467.46 & 0.0699 & 4 & 0.118 \\
\hline & & Lygaeidae & adult & 27.86 & 0.0042 & 1 & 0.030 \\
\hline & & Miridae & adult & 1906.95 & 0.2852 & 8 & 0.236 \\
\hline & & Pentatomidae & adult & 3961.49 & 0.5925 & 4 & 0.118 \\
\hline & & Reduviidae & adult & 229.46 & 0.0343 & 2 & 0.059 \\
\hline & & spp. & adult & 11655.89 & 1.7432 & 23 & 0.679 \\
\hline & & Achilidae & adult & 294.82 & 0.0441 & 12 & 0.354 \\
\hline & & Aphididae & adult & 3015.87 & 0.4510 & 355 & 10.475 \\
\hline & & Cercopidae & adult & 348.74 & 0.0522 & 5 & 0.148 \\
\hline & & Cicadellidae & adult & 4402.63 & 0.6585 & 36 & 1.062 \\
\hline & & Cixiidae & adult & 274.52 & 0.0411 & 6 & 0.177 \\
\hline & & Eriosomatidae & adult & 67.05 & 0.0100 & 4 & 0.118 \\
\hline & & Membracidae & adult & 2144.72 & 0.3208 & 5 & 0.148 \\
\hline & & spp. & adult & 2432.65 & 0.3638 & 11 & 0.325 \\
\hline & \multirow[t]{10}{*}{ Hymenoptera } & Braconidae & adult & 1993.67 & 0.2982 & 192 & 5.665 \\
\hline & & Chrysididae & adult & 12.00 & 0.0018 & 1 & 0.030 \\
\hline & & Colletidae & adult & 304.16 & 0.0455 & 1 & 0.030 \\
\hline & & Diapriidae & adult & 34.59 & 0.0052 & 6 & 0.177 \\
\hline & & Eulophidae & adult & 6.82 & 0.0010 & 2 & 0.059 \\
\hline & & Formicidae & adult & 14341.75 & 2.1449 & 243 & 7.170 \\
\hline & & Halictidae & adult & 515.97 & 0.0772 & 5 & 0.148 \\
\hline & & Ichneumonidae & adult & 579.75 & 0.0867 & 14 & 0.413 \\
\hline & & Mymaridae & adult & 1.14 & 0.0002 & 2 & 0.059 \\
\hline & & Pompilidae & adult & 47.39 & 0.0071 & 2 & 0.059 \\
\hline
\end{tabular}




\begin{tabular}{|c|c|c|c|c|c|c|c|}
\hline Season & Order & Family & Stage & $\begin{array}{l}\text { Combined } \\
\text { energy }(J)\end{array}$ & $\begin{array}{c}\% \text { of total } \\
\text { energy }\end{array}$ & Count & $\begin{array}{c}\% \text { of total } \\
\text { count } \\
\end{array}$ \\
\hline \multirow[t]{49}{*}{ Summer/Fall } & \multirow[t]{6}{*}{ Hymenoptera } & Pteromalidae & adult & 4.60 & 0.0007 & 3 & 0.089 \\
\hline & & spp. & adult & 7080.60 & 1.0590 & 38 & 1.121 \\
\hline & & spp. & larvae & 4204.90 & 0.6289 & 2 & 0.059 \\
\hline & & Tenthredinidae & adult & 3082.01 & 0.4609 & 3 & 0.089 \\
\hline & & Tiphiidae & adult & 76.11 & 0.0114 & 2 & 0.059 \\
\hline & & Vespidae & adult & 9603.58 & 1.4363 & 6 & 0.177 \\
\hline & \multirow[t]{6}{*}{ Isopoda } & spp. & adult & 11.48 & 0.0017 & 2 & 0.059 \\
\hline & & Hepialidae & adult & 1406.47 & 0.2103 & 1 & 0.030 \\
\hline & & Oecophoridae & adult & 10233.90 & 1.5306 & 1 & 0.030 \\
\hline & & Pyralidae & adult & 1854.53 & 0.2774 & 5 & 0.148 \\
\hline & & spp. & adult & 61357.07 & 9.1765 & 21 & 0.620 \\
\hline & & spp. & larvae & 183440.14 & 27.4351 & 291 & 8.587 \\
\hline & \multirow[t]{2}{*}{ Mecoptera } & Bittacidae & adult & 382.32 & 0.0572 & 2 & 0.059 \\
\hline & & Panorpidae & adult & 3731.48 & 0.5581 & 12 & 0.354 \\
\hline & Megaloptera & Corylophidae & adult & 55.65 & 0.0083 & 1 & 0.030 \\
\hline & Odonata & Petaluridae & larvae & 309.30 & 0.0463 & 1 & 0.030 \\
\hline & Oligochaeta & spp. & adult & 702.82 & 0.1051 & 1 & 0.030 \\
\hline & Opiliones & spp. & adult & 708.42 & 0.1059 & 36 & 1.062 \\
\hline & \multirow[t]{4}{*}{ Orthoptera } & Acrididae & adult & 3295.67 & 0.4929 & 3 & 0.089 \\
\hline & & Gryllacrididae & adult & 14925.45 & 2.2322 & 6 & 0.177 \\
\hline & & spp. & adult & 7974.34 & 1.1926 & 2 & 0.059 \\
\hline & & Tetrigidae & adult & 617.46 & 0.0923 & 2 & 0.059 \\
\hline & \multirow[t]{14}{*}{ Plecoptera } & Capniidae & adult & 108.46 & 0.0162 & 1 & 0.030 \\
\hline & & Capniidae & larvae & 61.22 & 0.0092 & 1 & 0.030 \\
\hline & & Chloroperlidae & adult & 368.91 & 0.0552 & 2 & 0.059 \\
\hline & & Chloroperlidae & larvae & 109.60 & 0.0164 & 5 & 0.148 \\
\hline & & Leuctridae & adult & 1322.61 & 0.1978 & 15 & 0.443 \\
\hline & & Leuctridae & larvae & 127.93 & 0.0191 & 25 & 0.738 \\
\hline & & Nemouridae & adult & 378.59 & 0.0566 & 5 & 0.148 \\
\hline & & Nemouridae & larvae & 36.75 & 0.0055 & 10 & 0.295 \\
\hline & & Peltoperlidae & larvae & 132.36 & 0.0198 & 2 & 0.059 \\
\hline & & Perlodidae & larvae & 41.04 & 0.0061 & 2 & 0.059 \\
\hline & & Pteronarcyidae & adult & 693.89 & 0.1038 & 1 & 0.030 \\
\hline & & Pteronarcyidae & larvae & 2280.72 & 0.3411 & 4 & 0.118 \\
\hline & & spp. & adult & 72.35 & 0.0108 & 3 & 0.089 \\
\hline & & spp. & larvae & 64.02 & 0.0096 & 4 & 0.118 \\
\hline & Psocoptera & Psocidae & adult & 40.70 & 0.0061 & 1 & 0.030 \\
\hline & Scorpaeniformes & Cottidae & adult & 44451.93 & 6.6482 & 10 & 0.295 \\
\hline & Thysanoptera & spp. & adult & 1.40 & 0.0002 & 1 & 0.030 \\
\hline & \multirow[t]{10}{*}{ Trichoptera } & Glossosomatidae & larvae & 313.27 & 0.0469 & 8 & 0.236 \\
\hline & & Hydropsychidae & adult & 1004.85 & 0.1503 & 14 & 0.413 \\
\hline & & Hydropsychidae & larvae & 699.19 & 0.1046 & 19 & 0.561 \\
\hline & & Lepidosomatidae & larvae & 31.81 & 0.0048 & 2 & 0.059 \\
\hline & & Limnephilidae & adult & 1297.62 & 0.1941 & 12 & 0.354 \\
\hline & & Limnephilidae & larvae & 777.03 & 0.1162 & 12 & 0.354 \\
\hline & & Philopotamidae & adult & 34.26 & 0.0051 & 1 & 0.030 \\
\hline & & Philopotamidae & larvae & 683.06 & 0.1022 & 28 & 0.826 \\
\hline & & Rhyacophilidae & larvae & 691.53 & 0.1034 & 7 & 0.207 \\
\hline & & spp. & adult & 168.78 & 0.0252 & 3 & 0.089 \\
\hline
\end{tabular}


Appendix A continued

\begin{tabular}{|c|c|c|c|c|c|c|c|}
\hline Season & Order & Family & Stage & $\begin{array}{l}\text { Combined } \\
\text { energy }(J)\end{array}$ & $\begin{array}{c}\% \text { of total } \\
\text { energy }\end{array}$ & Count & $\begin{array}{c}\% \text { of total } \\
\text { count } \\
\end{array}$ \\
\hline \multirow[t]{2}{*}{ Summer/Fall } & Trichoptera & spp. & larvae & 104.65 & 0.0157 & 2 & 0.059 \\
\hline & Total & & & 668632.70 & & 3389 & \\
\hline \multirow[t]{47}{*}{ Spring } & Anura & Hylidae & adult & 3687.03 & 0.2042 & 1 & 0.011 \\
\hline & Aranae & spp. & adult & 10726.88 & 0.5941 & 116 & 1.289 \\
\hline & Blattaria & Cryptocercidae & adult & 40212.55 & 2.2272 & 6 & 0.067 \\
\hline & Caudata & Plethodontidae & adult & 5876.88 & 0.3255 & 12 & 0.133 \\
\hline & Coleoptera & Anobiidae & adult & 13.98 & 0.0008 & 1 & 0.011 \\
\hline & & Buprestridae & adult & 1713.59 & 0.0949 & 4 & 0.044 \\
\hline & & Byrrhidae & adult & 117.73 & 0.0065 & 8 & 0.089 \\
\hline & & Cantharidae & adult & 5204.88 & 0.2883 & 47 & 0.522 \\
\hline & & Carabidae & adult & 82606.26 & 4.5751 & 135 & 1.501 \\
\hline & & Cerambycidae & adult & 16369.75 & 0.9066 & 41 & 0.456 \\
\hline & & Cerylonidae & adult & 3.39 & 0.0002 & 1 & 0.011 \\
\hline & & Chrysomelidae & adult & 63348.27 & 3.5085 & 249 & 2.768 \\
\hline & & Ciidae & adult & 6.83 & 0.0004 & 2 & 0.022 \\
\hline & & Cleridae & adult & 559.89 & 0.0310 & 4 & 0.044 \\
\hline & & Coccinellidae & adult & 6932.82 & 0.3840 & 22 & 0.245 \\
\hline & & Corylophidae & adult & 27.90 & 0.0015 & 4 & 0.044 \\
\hline & & Cucujidae & adult & 226.07 & 0.0125 & 10 & 0.111 \\
\hline & & Curculionidae & adult & 5363.33 & 0.2970 & 169 & 1.879 \\
\hline & & Dermestidae & adult & 36.31 & 0.0020 & 1 & 0.011 \\
\hline & & Dytiscidae & adult & 719.39 & 0.0398 & 4 & 0.044 \\
\hline & & Dytiscidae & larvae & 609.98 & 0.0338 & 8 & 0.089 \\
\hline & & Elateridae & adult & 26548.85 & 1.4704 & 138 & 1.534 \\
\hline & & Elmidae & adult & 92.37 & 0.0051 & 1 & 0.011 \\
\hline & & Elmidae & larvae & 395.50 & 0.0219 & 4 & 0.044 \\
\hline & & Eucnemidae & adult & 366.53 & 0.0203 & 4 & 0.044 \\
\hline & & Gyrinidae & adult & 417.02 & 0.0231 & 1 & 0.011 \\
\hline & & Gyrinidae & larvae & 349.28 & 0.0193 & 1 & 0.011 \\
\hline & & Helodidae & adult & 7.18 & 0.0004 & 2 & 0.022 \\
\hline & & Hydrophilidae & adult & 703.77 & 0.0390 & 12 & 0.133 \\
\hline & & Lathridiidae & adult & 34.78 & 0.0019 & 6 & 0.067 \\
\hline & & Lucanidae & adult & 11002.09 & 0.6093 & 30 & 0.333 \\
\hline & & Lyctidae & adult & 2004.36 & 0.1110 & 1 & 0.011 \\
\hline & & Melandryidae & adult & 121.30 & 0.0067 & 2 & 0.022 \\
\hline & & Mordellidae & adult & 34.30 & 0.0019 & 1 & 0.011 \\
\hline & & Mycetophagidae & adult & 88.76 & 0.0049 & 5 & 0.056 \\
\hline & & Nosodendridae & adult & 25.20 & 0.0014 & 1 & 0.011 \\
\hline & & Noteridae & adult & 810.16 & 0.0449 & 8 & 0.089 \\
\hline & & Phalacridae & adult & 57.75 & 0.0032 & 1 & 0.011 \\
\hline & & Pselaphidae & adult & 247.63 & 0.0137 & 16 & 0.178 \\
\hline & & Ptiliidae & adult & 6.00 & 0.0003 & 2 & 0.022 \\
\hline & & Rhizophagidae & adult & 145.95 & 0.0081 & 18 & 0.200 \\
\hline & & Rhysodidae & adult & 161.12 & 0.0089 & 1 & 0.011 \\
\hline & & Salpingidae & adult & 12.85 & 0.0007 & 2 & 0.022 \\
\hline & & Scarabaeidae & adult & 726166.24 & 40.2186 & 286 & 3.179 \\
\hline & & Scolytidae & adult & 5081.52 & 0.2814 & 268 & 2.979 \\
\hline & & spp. & adult & 16168.87 & 0.8955 & 143 & 1.590 \\
\hline & & Staphylinidae & adult & 13780.46 & 0.7632 & 208 & 2.312 \\
\hline
\end{tabular}


Appendix A continued

\begin{tabular}{|c|c|c|c|c|c|c|c|}
\hline Season & Order & Family & Stage & $\begin{array}{l}\text { Combined } \\
\text { energy }(J)\end{array}$ & $\begin{array}{c}\% \text { of total } \\
\text { energy }\end{array}$ & Count & $\begin{array}{c}\% \text { of total } \\
\text { count }\end{array}$ \\
\hline \multirow[t]{49}{*}{ Spring } & Coleoptera & Tenebrionidae & adult & 1577.71 & 0.0874 & 3 & 0.033 \\
\hline & Collembola & Isotomidae & adult & 115.49 & 0.0064 & 21 & 0.233 \\
\hline & & Sminthuridae & adult & 209.25 & 0.0116 & 29 & 0.322 \\
\hline & & spp. & adult & 30.16 & 0.0017 & 3 & 0.033 \\
\hline & Cypriniformes & Cyprinidae & adult & 131.16 & 0.0073 & 1 & 0.011 \\
\hline & Decapoda & Cambaridae & adult & 42304.91 & 2.3431 & 52 & 0.578 \\
\hline & Diplopoda & spp. & adult & 68274.55 & 3.7814 & 32 & 0.356 \\
\hline & Diptera & Anisopodidae & adult & 99.82 & 0.0055 & 2 & 0.022 \\
\hline & & Anthomyzidae & adult & 49.08 & 0.0027 & 1 & 0.011 \\
\hline & & Asilidae & adult & 20744.84 & 1.1490 & 28 & 0.311 \\
\hline & & Bibionidae & adult & 3620.97 & 0.2005 & 29 & 0.322 \\
\hline & & Bombyliidae & adult & 82.49 & 0.0046 & 1 & 0.011 \\
\hline & & Cecidomyiidae & adult & 78.70 & 0.0044 & 3 & 0.033 \\
\hline & & Ceratopogonidae & adult & 1874.84 & 0.1038 & 42 & 0.467 \\
\hline & & Chironomidae & adult & 21.58 & 0.0012 & 39 & 0.434 \\
\hline & & Chironomidae & larvae & 97.65 & 0.0054 & 45 & 0.500 \\
\hline & & Dolichopodidae & adult & 1700.37 & 0.0942 & 58 & 0.645 \\
\hline & & Drosophilidae & adult & 168.57 & 0.0093 & 13 & 0.145 \\
\hline & & Empididae & adult & 90432.84 & 5.0086 & 1802 & 20.031 \\
\hline & & Empididae & larvae & 277.39 & 0.0154 & 34 & 0.378 \\
\hline & & Heleomyzidae & adult & 63.48 & 0.0035 & 4 & 0.044 \\
\hline & & Muscidae & adult & 943.31 & 0.0522 & 29 & 0.322 \\
\hline & & Mycetophilidae & adult & 1900.10 & 0.1052 & 110 & 1.223 \\
\hline & & Phoridae & adult & 202.37 & 0.0112 & 26 & 0.289 \\
\hline & & Pipunculidae & adult & 93.61 & 0.0052 & 4 & 0.044 \\
\hline & & Rhagionidae & adult & 9647.20 & 0.5343 & 38 & 0.422 \\
\hline & & Scatopsidae & adult & 79.59 & 0.0044 & 2 & 0.022 \\
\hline & & Sciaridae & adult & 1752.53 & 0.0971 & 92 & 1.023 \\
\hline & & Sciomyzidae & adult & 2701.04 & 0.1496 & 28 & 0.311 \\
\hline & & Simuliidae & adult & 67.00 & 0.0037 & 53 & 0.589 \\
\hline & & Simuliidae & larvae & 66.54 & 0.0037 & 20 & 0.222 \\
\hline & & spp. & adult & 88542.46 & 4.9039 & 649 & 7.214 \\
\hline & & spp. & larvae & 982.62 & 0.0544 & 826 & 9.182 \\
\hline & & spp. & pupae & 852.97 & 0.0472 & 73 & 0.811 \\
\hline & & Stratiomyidae & adult & 268.67 & 0.0149 & 2 & 0.022 \\
\hline & & Syrphidae & adult & 6377.50 & 0.3532 & 31 & 0.345 \\
\hline & & Tabanidae & adult & 194.60 & 0.0108 & 3 & 0.033 \\
\hline & & Tephritidae & adult & 167.98 & 0.0093 & 5 & 0.056 \\
\hline & & Therevidae & adult & 85.41 & 0.0047 & 1 & 0.011 \\
\hline & & Tipulidae & adult & 20922.66 & 1.1588 & 167 & 1.856 \\
\hline & & Tipulidae & larvae & 14832.53 & 0.8215 & 24 & 0.267 \\
\hline & & Xylophagidae & adult & 386.14 & 0.0214 & 5 & 0.056 \\
\hline & Ephemeroptera & Ameletidae & larvae & 1118.54 & 0.0620 & 20 & 0.222 \\
\hline & & Baetidae & adult & 639.21 & 0.0354 & 33 & 0.367 \\
\hline & & Baetidae & larvae & 962.77 & 0.0533 & 78 & 0.867 \\
\hline & & Ephemerellidae & adult & 104.53 & 0.0058 & 3 & 0.033 \\
\hline & & Ephemerellidae & larvae & 2393.63 & 0.1326 & 43 & 0.478 \\
\hline & & Heptageniidae & adult & 340.31 & 0.0188 & 2 & 0.022 \\
\hline & & Heptageniidae & larvae & 15048.76 & 0.8335 & 121 & 1.345 \\
\hline
\end{tabular}




\begin{tabular}{|c|c|c|c|c|c|c|c|}
\hline Season & Order & Family & Stage & $\begin{array}{l}\text { Combined } \\
\text { energy }(J)\end{array}$ & $\begin{array}{c}\% \text { of total } \\
\text { energy }\end{array}$ & Count & $\begin{array}{c}\% \text { of total } \\
\text { count } \\
\end{array}$ \\
\hline \multirow[t]{49}{*}{ Spring } & Ephemeroptera & Potamanthidae & larvae & 178.15 & 0.0099 & 6 & 0.067 \\
\hline & & spp. & adult & 3971.15 & 0.2199 & 42 & 0.467 \\
\hline & & spp. & larvae & 5022.06 & 0.2781 & 35 & 0.389 \\
\hline & Gastropoda & spp. & adult & 1.13 & 0.0001 & 4 & 0.044 \\
\hline & Hemiptera & Acanthosomatidae & adult & 132.36 & 0.0073 & 1 & 0.011 \\
\hline & & Cydnidae & adult & 2288.00 & 0.1267 & 278 & 3.090 \\
\hline & & Gerridae & adult & 5422.35 & 0.3003 & 25 & 0.278 \\
\hline & & Lygaeidae & adult & 85.32 & 0.0047 & 4 & 0.044 \\
\hline & & Miridae & adult & 85.10 & 0.0047 & 3 & 0.033 \\
\hline & & Pentatomidae & adult & 19882.72 & 1.1012 & 8 & 0.089 \\
\hline & & Reduviidae & adult & 36.93 & 0.0020 & 3 & 0.033 \\
\hline & & spp. & adult & 745.04 & 0.0413 & 10 & 0.111 \\
\hline & & Veliidae & adult & 8.46 & 0.0005 & 3 & 0.033 \\
\hline & Homoptera & Aphididae & adult & 245.87 & 0.0136 & 50 & 0.556 \\
\hline & & Cercopidae & adult & 103.06 & 0.0057 & 3 & 0.033 \\
\hline & & Cicadellidae & adult & 4010.48 & 0.2221 & 112 & 1.245 \\
\hline & & Cixiidae & adult & 255.52 & 0.0142 & 9 & 0.100 \\
\hline & & Delphacidae & adult & 21.18 & 0.0012 & 1 & 0.011 \\
\hline & & Eriosomatidae & adult & 1.72 & 0.0001 & 1 & 0.011 \\
\hline & & spp. & adult & 508.11 & 0.0281 & 21 & 0.233 \\
\hline & Hymenoptera & Andrenidae & adult & 217.05 & 0.0120 & 1 & 0.011 \\
\hline & & Anthophoridae & adult & 416.03 & 0.0230 & 3 & 0.033 \\
\hline & & Apidae & adult & 4938.41 & 0.2735 & 3 & 0.033 \\
\hline & & Braconidae & adult & 1070.98 & 0.0593 & 80 & 0.889 \\
\hline & & Colletidae & adult & 9291.29 & 0.5146 & 11 & 0.122 \\
\hline & & Cynipidae & adult & 26.06 & 0.0014 & 5 & 0.056 \\
\hline & & Diapriidae & adult & 74.61 & 0.0041 & 19 & 0.211 \\
\hline & & Encyrtidae & adult & 2.53 & 0.0001 & 1 & 0.011 \\
\hline & & Eucoilidae & adult & 126.35 & 0.0070 & 5 & 0.056 \\
\hline & & Eulophidae & adult & 231.25 & 0.0128 & 9 & 0.100 \\
\hline & & Eurytomidae & adult & 3.89 & 0.0002 & 1 & 0.011 \\
\hline & & Formicidae & adult & 18081.36 & 1.0014 & 251 & 2.790 \\
\hline & & Heloridae & adult & 2.68 & 0.0001 & 1 & 0.011 \\
\hline & & Ichneumonidae & adult & 1553.81 & 0.0861 & 28 & 0.311 \\
\hline & & Megachilidae & adult & 468.42 & 0.0259 & 3 & 0.033 \\
\hline & & Mymaridae & adult & 39.64 & 0.0022 & 15 & 0.167 \\
\hline & & Pompilidae & adult & 366.19 & 0.0203 & 1 & 0.011 \\
\hline & & Pteromalidae & adult & 23.42 & 0.0013 & 11 & 0.122 \\
\hline & & Sphecidae & adult & 55.79 & 0.0031 & 1 & 0.011 \\
\hline & & spp. & adult & 49419.44 & 2.7371 & 95 & 1.056 \\
\hline & & Tenthredinidae & adult & 564.78 & 0.0313 & 15 & 0.167 \\
\hline & & Tiphiidae & adult & 402.42 & 0.0223 & 4 & 0.044 \\
\hline & & Vespidae & adult & 472.43 & 0.0262 & 3 & 0.033 \\
\hline & Isopoda & spp. & adult & 30.45 & 0.0017 & 1 & 0.011 \\
\hline & Lepidoptera & Psychidae & adult & 692.48 & 0.0384 & 1 & 0.011 \\
\hline & & Pyralidae & adult & 6037.78 & 0.3344 & 19 & 0.211 \\
\hline & & spp. & adult & 4238.50 & 0.2347 & 9 & 0.100 \\
\hline & & spp. & larvae & 62554.73 & 3.4646 & 151 & 1.679 \\
\hline & Mecoptera & Bittacidae & adult & 238.89 & 0.0132 & 1 & 0.011 \\
\hline
\end{tabular}




\begin{tabular}{|c|c|c|c|c|c|c|c|}
\hline Season & Order & Family & Stage & $\begin{array}{l}\text { Combined } \\
\text { energy }(J)\end{array}$ & $\begin{array}{c}\% \text { of total } \\
\text { energy }\end{array}$ & Count & $\begin{array}{c}\% \text { of total } \\
\text { count } \\
\end{array}$ \\
\hline \multirow[t]{49}{*}{ Spring } & Mecoptera & Panorpidae & adult & 1193.22 & 0.0661 & 6 & 0.067 \\
\hline & Neuroptera & Coniopterygidae & adult & 2.36 & 0.0001 & 10 & 0.111 \\
\hline & Odonata & Gomphidae & adult & 4704.41 & 0.2606 & 1 & 0.011 \\
\hline & & Gomphidae & larvae & 2210.57 & 0.1224 & 3 & 0.033 \\
\hline & & spp. & larvae & 281.19 & 0.0156 & 1 & 0.011 \\
\hline & Oligochaeta & spp. & adult & 761.10 & 0.0422 & 3 & 0.033 \\
\hline & Opiliones & spp. & adult & 169.34 & 0.0094 & 15 & 0.167 \\
\hline & Orthoptera & Acrididae & adult & 11538.96 & 0.6391 & 10 & 0.111 \\
\hline & & Gryllacrididae & adult & 201.25 & 0.0111 & 1 & 0.011 \\
\hline & & spp. & adult & 5407.36 & 0.2995 & 2 & 0.022 \\
\hline & & Tetrigidae & adult & 371.08 & 0.0206 & 1 & 0.011 \\
\hline & Plecoptera & Capniidae & larvae & 306.92 & 0.0170 & 3 & 0.033 \\
\hline & & Chloroperlidae & adult & 2109.41 & 0.1168 & 10 & 0.111 \\
\hline & & Chloroperlidae & larvae & 1158.50 & 0.0642 & 36 & 0.400 \\
\hline & & Leuctridae & adult & 10457.40 & 0.5792 & 74 & 0.823 \\
\hline & & Leuctridae & larvae & 409.01 & 0.0227 & 41 & 0.456 \\
\hline & & Nemouridae & adult & 2262.57 & 0.1253 & 17 & 0.189 \\
\hline & & Nemouridae & larvae & 327.91 & 0.0182 & 63 & 0.700 \\
\hline & & Peltoperlidae & adult & 219.27 & 0.0121 & 1 & 0.011 \\
\hline & & Peltoperlidae & larvae & 1479.31 & 0.0819 & 14 & 0.156 \\
\hline & & Perlidae & adult & 815.59 & 0.0452 & 1 & 0.011 \\
\hline & & Perlidae & larvae & 902.25 & 0.0500 & 5 & 0.056 \\
\hline & & Perlodidae & adult & 1030.94 & 0.0571 & 3 & 0.033 \\
\hline & & Perlodidae & larvae & 2487.95 & 0.1378 & 28 & 0.311 \\
\hline & & Pteronarcyidae & adult & 32237.31 & 1.7855 & 25 & 0.278 \\
\hline & & Pteronarcyidae & larvae & 21280.42 & 1.1786 & 16 & 0.178 \\
\hline & & spp. & adult & 644.43 & 0.0357 & 12 & 0.133 \\
\hline & & spp. & larvae & 1414.37 & 0.0783 & 34 & 0.378 \\
\hline & & Taeniopterygidae & adult & 505.51 & 0.0280 & 3 & 0.033 \\
\hline & & Taeniopterygidae & larvae & 151.01 & 0.0084 & 15 & 0.167 \\
\hline & Scorpaeniformes & Cottidae & adult & 18650.15 & 1.0329 & 6 & 0.067 \\
\hline & Thysanoptera & Heterothripidae & adult & 4.34 & 0.0002 & 1 & 0.011 \\
\hline & & Phlaeothripidae & adult & 2.63 & 0.0001 & 1 & 0.011 \\
\hline & Trichoptera & Brachycentridae & adult & 12.98 & 0.0007 & 1 & 0.011 \\
\hline & & Georyssidae & adult & 109.74 & 0.0061 & 3 & 0.033 \\
\hline & & Georyssidae & larvae & 42.14 & 0.0023 & 1 & 0.011 \\
\hline & & Glossosomatidae & adult & 41.56 & 0.0023 & 1 & 0.011 \\
\hline & & Glossosomatidae & larvae & 30.10 & 0.0017 & 3 & 0.033 \\
\hline & & Hydropsychidae & adult & 955.10 & 0.0529 & 17 & 0.189 \\
\hline & & Hydropsychidae & larvae & 4800.32 & 0.2659 & 78 & 0.867 \\
\hline & & Lepidosomatidae & larvae & 70.54 & 0.0039 & 4 & 0.044 \\
\hline & & Limnephilidae & adult & 2281.36 & 0.1264 & 46 & 0.511 \\
\hline & & Limnephilidae & larvae & 5527.02 & 0.3061 & 141 & 1.567 \\
\hline & & Philopotamidae & adult & 277.21 & 0.0154 & 4 & 0.044 \\
\hline & & Philopotamidae & larvae & 1091.23 & 0.0604 & 64 & 0.711 \\
\hline & & Phryganeidae & adult & 380.15 & 0.0211 & 1 & 0.011 \\
\hline & & Phryganeidae & larvae & 414.60 & 0.0230 & 4 & 0.044 \\
\hline & & Polycentropodidae & larvae & 15.05 & 0.0008 & 1 & 0.011 \\
\hline & & Rhyacophilidae & adult & 182.31 & 0.0101 & 2 & 0.022 \\
\hline
\end{tabular}


Appendix A continued

\begin{tabular}{|c|c|c|c|c|c|c|c|}
\hline Season & Order & Family & Stage & $\begin{array}{l}\text { Combined } \\
\text { energy }(\mathbf{J})\end{array}$ & $\begin{array}{c}\begin{array}{c}\% \text { of total } \\
\text { energy }\end{array} \\
\end{array}$ & Count & $\begin{array}{c}\% \text { of total } \\
\text { count }\end{array}$ \\
\hline \multirow[t]{6}{*}{ Spring } & Trichoptera & Rhyacophilidae & larvae & 1984.79 & 0.1099 & 17 & 0.189 \\
\hline & & spp. & adult & 3578.04 & 0.1982 & 30 & 0.333 \\
\hline & & spp. & larvae & 481.24 & 0.0267 & 8 & 0.089 \\
\hline & & Uenoidae & larvae & 102.24 & 0.0057 & 3 & 0.033 \\
\hline & Zoraptera & Zorotypidae & adult & 0.25 & 0.0000 & 1 & 0.011 \\
\hline & Total & & & 1805546.37 & & 8996 & \\
\hline \multirow[t]{43}{*}{ Winter } & Acarina & spp. & adult & 3.18 & 0.0014 & 1 & 0.054 \\
\hline & Aranae & spp. & adult & 802.32 & 0.3611 & 21 & 1.133 \\
\hline & Caudata & Plethodontidae & adult & 3729.55 & 1.6787 & 5 & 0.270 \\
\hline & Coleoptera & Carabidae & adult & 22.22 & 0.0100 & 1 & 0.054 \\
\hline & & Curculionidae & adult & 47.18 & 0.0212 & 2 & 0.108 \\
\hline & & Dytiscidae & larvae & 7330.89 & 3.2997 & 15 & 0.809 \\
\hline & & Erotylidae & adult & 34.29 & 0.0154 & 1 & 0.054 \\
\hline & & Georyssidae & larvae & 114.38 & 0.0515 & 1 & 0.054 \\
\hline & & Gyrinidae & larvae & 1192.04 & 0.5365 & 1 & 0.054 \\
\hline & & Pselaphidae & adult & 8.88 & 0.0040 & 1 & 0.054 \\
\hline & & Scolytidae & adult & 17.07 & 0.0077 & 1 & 0.054 \\
\hline & & spp. & adult & 648.34 & 0.2918 & 6 & 0.324 \\
\hline & & Staphylinidae & adult & 202.56 & 0.0912 & 7 & 0.378 \\
\hline & & Isotomidae & adult & 30.99 & 0.0140 & 11 & 0.593 \\
\hline & & Sminthuridae & adult & 29.64 & 0.0133 & 7 & 0.378 \\
\hline & Decapoda & Cambaridae & adult & 1995.95 & 0.8984 & 7 & 0.378 \\
\hline & Diptera & Cecidomyiidae & adult & 51.66 & 0.0233 & 2 & 0.108 \\
\hline & & Ceratopogonidae & adult & 195.70 & 0.0881 & 8 & 0.431 \\
\hline & & Chironomidae & adult & 4.73 & 0.0021 & 6 & 0.324 \\
\hline & & Chironomidae & larvae & 66.86 & 0.0301 & 40 & 2.157 \\
\hline & & Drosophilidae & adult & 5.18 & 0.0023 & 1 & 0.054 \\
\hline & & Empididae & larvae & 4.46 & 0.0020 & 1 & 0.054 \\
\hline & & Mycetophilidae & adult & 52.90 & 0.0238 & 1 & 0.054 \\
\hline & & Phoridae & adult & 6.34 & 0.0029 & 1 & 0.054 \\
\hline & & Sciaridae & adult & 44.52 & 0.0200 & 3 & 0.162 \\
\hline & & Simuliidae & adult & 1.20 & 0.0005 & 1 & 0.054 \\
\hline & & Simuliidae & larvae & 107.25 & 0.0483 & 13 & 0.701 \\
\hline & & spp. & adult & 15.75 & 0.0071 & 2 & 0.108 \\
\hline & & spp. & larvae & 97.46 & 0.0439 & 3 & 0.162 \\
\hline & & spp. & pupae & 0.64 & 0.0003 & 1 & 0.054 \\
\hline & & Tipulidae & larvae & 8776.12 & 3.9502 & 25 & 1.348 \\
\hline & & Xiphocentronidae & adult & 33.79 & 0.0152 & 1 & 0.054 \\
\hline & Ephemeroptera & Ameletidae & larvae & 388.21 & 0.1747 & 13 & 0.701 \\
\hline & & Baetidae & larvae & 403.62 & 0.1817 & 29 & 1.564 \\
\hline & & Ephemerellidae & larvae & 2928.06 & 1.3179 & 25 & 1.348 \\
\hline & & Heptageniidae & larvae & 15595.84 & 7.0198 & 88 & 4.746 \\
\hline & & Isotomidae & larvae & 32.80 & 0.0148 & 3 & 0.162 \\
\hline & & Leptophlebiidae & larvae & 17.46 & 0.0079 & 1 & 0.054 \\
\hline & & Potamanthidae & larvae & 834.18 & 0.3755 & 2 & 0.108 \\
\hline & & spp. & larvae & 240.80 & 0.1084 & 5 & 0.270 \\
\hline & Hemiptera & Gerridae & adult & 1094.03 & 0.4924 & 6 & 0.324 \\
\hline & & spp. & adult & 3.95 & 0.0018 & 1 & 0.054 \\
\hline & Homoptera & Aphididae & adult & 2.72 & 0.0012 & 1 & 0.054 \\
\hline
\end{tabular}




\begin{tabular}{|c|c|c|c|c|c|c|c|}
\hline Season & Order & Family & Stage & $\begin{array}{l}\text { Combined } \\
\text { energy }(J)\end{array}$ & $\begin{array}{c}\% \text { of total } \\
\text { energy }\end{array}$ & Count & $\begin{array}{c}\% \text { of total } \\
\text { count }\end{array}$ \\
\hline \multirow[t]{43}{*}{ Winter } & Homoptera & Cicadellidae & adult & 20.91 & 0.0094 & 1 & 0.054 \\
\hline & & Psyllidae & adult & 5.86 & 0.0026 & 1 & 0.054 \\
\hline & Hymenoptera & Andrenidae & adult & 361.52 & 0.1627 & 1 & 0.054 \\
\hline & & Formicidae & adult & 71.47 & 0.0322 & 3 & 0.162 \\
\hline & & Ichneumonidae & adult & 17.36 & 0.0078 & 1 & 0.054 \\
\hline & Lepidoptera & spp. & larvae & 22.87 & 0.0103 & 3 & 0.162 \\
\hline & Megaloptera & Corylophidae & larvae & 1681.11 & 0.7567 & 1 & 0.054 \\
\hline & Odonata & Gomphidae & larvae & 845.36 & 0.3805 & 3 & 0.162 \\
\hline & Oligochaeta & spp. & adult & 470.27 & 0.2117 & 2 & 0.108 \\
\hline & Plecoptera & Capniidae & adult & 2462.36 & 1.1083 & 29 & 1.564 \\
\hline & & Capniidae & larvae & 393.43 & 0.1771 & 7 & 0.378 \\
\hline & & Chloroperlidae & larvae & 96.70 & 0.0435 & 5 & 0.270 \\
\hline & & Leuctridae & adult & 120.96 & 0.0544 & 1 & 0.054 \\
\hline & & Leuctridae & larvae & 269.14 & 0.1211 & 39 & 2.104 \\
\hline & & Nemouridae & adult & 1126.62 & 0.5071 & 9 & 0.485 \\
\hline & & Nemouridae & larvae & 169.56 & 0.0763 & 21 & 1.133 \\
\hline & & Peltoperlidae & larvae & 371.16 & 0.1671 & 8 & 0.431 \\
\hline & & Perlodidae & larvae & 2521.49 & 1.1349 & 34 & 1.834 \\
\hline & & Pteronarcyidae & larvae & 29635.01 & 13.3389 & 11 & 0.593 \\
\hline & & spp. & adult & 473.56 & 0.2132 & 18 & 0.971 \\
\hline & & spp. & larvae & 265.33 & 0.1194 & 14 & 0.755 \\
\hline & & Taeniopterygidae & adult & 348.57 & 0.1569 & 3 & 0.162 \\
\hline & & Taeniopterygidae & larvae & 373.12 & 0.1679 & 21 & 1.133 \\
\hline & Salmoniformes & Salmonidae & adult & 25077.48 & 11.2875 & 2 & 0.108 \\
\hline & Scorpaeniformes & Cottidae & adult & 3600.47 & 1.6206 & 2 & 0.108 \\
\hline & Trichoptera & Brachycentridae & adult & 338.29 & 0.1523 & 3 & 0.162 \\
\hline & & Brachycentridae & larvae & 1878.82 & 0.8457 & 15 & 0.809 \\
\hline & & Georyssidae & larvae & 218.79 & 0.0985 & 4 & 0.216 \\
\hline & & Glossosomatidae & larvae & 26.47 & 0.0119 & 1 & 0.054 \\
\hline & & Helicopsychidae & adult & 31.75 & 0.0143 & 1 & 0.054 \\
\hline & & Helicopsychidae & larvae & 318.18 & 0.1432 & 1 & 0.054 \\
\hline & & Hydropsychidae & larvae & 2061.85 & 0.9281 & 41 & 2.211 \\
\hline & & Lepidosomatidae & larvae & 1297.10 & 0.5838 & 25 & 1.348 \\
\hline & & Limnephilidae & adult & 5902.11 & 2.6566 & 136 & 7.335 \\
\hline & & Limnephilidae & larvae & 58821.67 & 26.4759 & 524 & 28.263 \\
\hline & & Philopotamidae & adult & 12432.07 & 5.5957 & 202 & 10.895 \\
\hline & & Philopotamidae & larvae & 498.07 & 0.2242 & 18 & 0.971 \\
\hline & & Phryganeidae & larvae & 2995.20 & 1.3482 & 8 & 0.431 \\
\hline & & Polycentropodidae & larvae & 62.85 & 0.0283 & 3 & 0.162 \\
\hline & & Rhyacophilidae & larvae & 250.09 & 0.1126 & 7 & 0.378 \\
\hline & & spp. & adult & 8433.75 & 3.7961 & 165 & 8.900 \\
\hline & & spp. & larvae & 8585.83 & 3.8645 & 89 & 4.800 \\
\hline & Total & & & 222170.31 & & 1854 & \\
\hline
\end{tabular}


Appendix B (Fish species in each site): Fish species captured in each site over the course of the study. All sites contained brook trout; if brook trout was the only fish species encountered it is noted on the table. Scientific and common names are provided.

\begin{tabular}{lll}
\hline Site name & Scientific name & Common name \\
\hline Brushy Run & Brook trout only & - \\
KittleLOW & Catostomus commersoni & White sucker \\
& Cottus bairdi & Mottled Sculpin \\
& Etheostoma flabellare & Fantail darter \\
& Hypentelium nigricans & Northern hogsucker \\
& Rhinichthys cataractae & Longnose dace \\
& Rhinichthys obtusis & Blacknose dace \\
& Semotilus atromaculatus & Creek chub \\
KittleMID & Cottus bairdi & Mottled Sculpin \\
& Rhinichthys cataractae & Longnose dace \\
KittleUP & Cottus bairdi & Mottled Sculpin \\
Light & Cottus bairdi & Mottled Sculpin \\
& Rhinichthys cataractae & Longnose dace \\
& Rhinichthys obtusis & Blacknose dace \\
Mitchell & Semotilus atromaculatus & Creek chub \\
RockyLOW & Cottus bairdi & Mottled Sculpin \\
& Catostomus commersoni & White sucker \\
& Cottus bairdi & Mottled Sculpin \\
& Hypentelium nigricans & Northern hogsucker \\
& Rhinichthys cataractae & Longnose dace \\
RockyUP & Rhinichthys obtusis & Blacknose dace \\
Sugar & Semotilus atromaculatus & Creek chub \\
\hline
\end{tabular}




\section{Ryan M. Utz \\ Curriculum vitae}

414 Pennsylvania Ave.

Morgantown, WV 26501

rutz@mix.wvu.edu

work/home: 724-272-7769

\section{Education}

West Virginia University (WVU), Morgantown, WV: M.S. in Fisheries Resources, graduation date: December 2005

- Master's Thesis: Temporal trends in consumption, growth and successful feeding traits of a central Appalachain brook trout population at the watershed scale Advisor: Dr. Kyle Hartman

Pertinent Coursework: Fisheries Management, Statistics (x2), Fish Ecology, GIS, Fish Physiology, Advanced Ichthyology, Quantitative Ecology, Limnology Total Credits: 40 currently, 52 expected (semester system), current GPA 4.00

University of Miami (UM), Coral Gables, FL: B.S. in Biology

Pertinent Coursework: Ecology, Genetics, Tropical Field Biology, Chemical Oceanography, Biometrics, Aquaculture, Marine Biology, Organic Chemistry (x2), Calculus (x2)

Total Credits: 116 (semester system), final GPA: 3.80

\section{Professional Experience}

Graduate Research Assistant, WVU, Morgantown, WV May '04-Present

- Included personal research, research for collaborative long-term project, and assisting other graduate students with field work.

Duties involved: backpack electrofishing, BVET habitat analysis, stomach lavage (brook trout), elastomer tagging, insect identification, sediment analysis, larval fish trapping, organizing \& leading field crew, data entry and analysis Work Load: Minimum $20 \mathrm{hrs} /$ week, usually $40+$. Salary of $\sim \$ 820 /$ month Supervisor: Dr. Kyle Hartman

Graduate Teaching Assistant, WVU, Morgantown, WV Aug '03-May'04

- Included overseeing four introductory biology labs.

Duties Involved: Preparation of teaching material, lecturing, instruction and assistance with basic lab techniques (microscopy, bacteria culture, etc.), evaluation of student work Work Load: Minimum 20hrs/week, usually $\sim 30$. Salary of $\sim \$ 960 /$ month Supervisor: Dr. Jane Caldwell 
Undergraduate Research Assistant/Intern, UM, Turrialba, Costa Rica June-Aug '02

- Included assisting doctoral candidate with her research at the Centro Agronomo Tropical de Investigation y Enseñanza (CATIE)

Duties Involved: Assisting with experimental design/implementation, soil collection, plant maintanence, mycorrhizal fungus identification (in lab) Work Load: 40 hours/week. No paid salary (housing and meals provided) Supervisors: Drs. Michelle Schroeder and Dave Janos

\section{$\underline{\text { Volunteer Experience }}$}

Earthwatch Volunteer, Mindo, Ecuador July 2000

- Involved assisting with field work for several projects

Duties Involved: Mist netting (birds), vegetation surveys

Supervisor: Dr. Dusty Becker (Kansas State University)

Earthwatch Volunteer, Tanjung Puting National Park, Indonesia July 1999

- Involved assisting with field work for several projects

Duties Involved: DBH on forest trees, primate surveys

Supervisor: Dr. Carey Yeager (University of Florida)

\section{Skills and Qualifications}

\section{Computer Skills}

Familiar with the following software: SAS, SPSS, NTSys, MARK, CAPTURE, ArcGIS, Fish Bioenergetics, ProCite, Microsoft Access, Excel, Word, and Powerpoint

\section{Written and Oral Communication}

Public research presentations, poster presentations, formal seminar presentations

\section{SCUBA-Advanced Certified}

\section{Certified CPR and First Aid}




\section{Professional Affiliations}

American Fisheries Society

Member of national chapter since 2003

Member of WV chapter since 2003

Member WVU student chapter since 2003

American Institute of Fishery Research Biologists

Member since 2005

\section{Honors and Awards}

Best Student Presenter- February 2005 Joint Meeting of American Fisheries Society, Society of American Foresters, and The Wildlife Society (West Virginia State Chapters)

Graduated with General Honors- UM May 2003

- Awarded to students graduating after completing at least 20 credits of honors level classes and with a cumulative GPA of 3.6 or higher

Graduated Cum Laude- UM May 2003

Various Academic Lists- UM (August 1999 to May 2003)

- President's List (1/7 semesters)

- Provost's List (4/7 semesters)

- Dean's List (6/7 semesters)

George Merrick Scholarship- August 1999 to May 2003

- Awarded to students entering UM with academic achievement, continued through degree pending GPA

\section{Public Presentations}

Utz, R. M. and K. J. Hartman. 2005. Patterns of spatial and temporal feeding ecology of a mid-Appalachian brook trout population. East Coast Trout Management and Culture Workshop IV. Lock Haven, PA. June 7, 2005. 
Utz, R.M., and K. J. Hartman. 2005. Patterns of spatial and temporal feeding ecology of a mid-Appalachian brook trout population. Davis College of Agriculture, Forestry, and Consumer Science Ninth Annual Graduate Student Research Conference (WVU). Morgantown, WV. April 14, 2005.

Hartman, K. J., Niles, J., Utz, R. M., Webster, J. W., and B. Moore. 2005. Assessment of spatial and temporal variability in stream habitat and its influence on brook trout population dynamics. Poster. Annual meeting of Mead-Westvaco Research Forest supporters. Charleston, WV. February 17, 2005.

Utz, R.M., and K. J. Hartman. 2005. Temporal trends in energy storage, consumption, and growth in a population of central Appalachian brook trout. Joint meeting of the WV Society of Foresters, Wildlife Society, and American Fisheries Society. Flatwoods, WV. February 5, 2005.

Utz, R.M., and K. J. Hartman. 2005. Temporal trends in energy storage, consumption, and growth in a population of central Appalachian brook trout. Southern Division American Fisheries Society spring meeting. Virginia Beach, VA. February 12, 2005.

Utz, R.M., and K. J. Hartman. 2004. Dynamic patterns of energy storage in a central Appalachian brook trout population with respect to seasonal change, food availability, and growth. American Fisheries Society Southern Division 4th Annual Student Colloquium. St. Augustine, FL. November 6, 2004

\section{$\underline{\text { References }}$}

Kyle Hartman, Ph.D. Professor of Fisheries West Virginia University Division of Forestry Morgantown, WV 26506 hartman@wvu.edu 304-293-2941 x2494
Jane Caldwell, Ph.D.

Professor of Biology

West Virginia University 3139 Life Sciences Bldg Morgantown, WV 26506 jane.caldwell@mail.wvu.edu 304-293-5201 x31500
Pat Mazik, Ph.D.

Unit Leader USGS COOP Unit, WVU 333 Percival Hall Morgantown, WV 26506 pmazik@wvu.edu 304-293-2941 x2431
David Janos, Ph.D.

Professor of Biology

University of Miami

166A Cox Science Center

1301 Memorial Drive

Coral Gables, FL 33146

davidjanos@miami.edu

305-284-6300
Michelle Schroeder, Ph.D.

Teaching Assistant Professor

North Carolina State University

2406 Williams Hall Box 7620

Raleigh, NC 27695-7620

Michelle_schroeder@ncsu.edu 919-513-0085 